\title{
Pediatric interhospital intensive care transport in the Netherlands: current situation and future perspectives
}

Citation for published version (APA):

Vos, G. D. (2004). Pediatric interhospital intensive care transport in the Netherlands: current situation and future perspectives. [Doctoral Thesis, Maastricht University]. Maastricht University. https://doi.org/10.26481/dis.20040205gv

Document status and date:

Published: 01/01/2004

DOI:

10.26481/dis.20040205gv

Document Version:

Publisher's PDF, also known as Version of record

\section{Please check the document version of this publication:}

- A submitted manuscript is the version of the article upon submission and before peer-review. There can be important differences between the submitted version and the official published version of record.

People interested in the research are advised to contact the author for the final version of the publication, or visit the DOI to the publisher's website.

- The final author version and the galley proof are versions of the publication after peer review.

- The final published version features the final layout of the paper including the volume, issue and page numbers.

Link to publication

\footnotetext{
General rights rights.

- You may freely distribute the URL identifying the publication in the public portal. please follow below link for the End User Agreement:

www.umlib.nl/taverne-license

Take down policy

If you believe that this document breaches copyright please contact us at:

repository@maastrichtuniversity.nl

providing details and we will investigate your claim.
}

Copyright and moral rights for the publications made accessible in the public portal are retained by the authors and/or other copyright owners and it is a condition of accessing publications that users recognise and abide by the legal requirements associated with these

- Users may download and print one copy of any publication from the public portal for the purpose of private study or research.

- You may not further distribute the material or use it for any profit-making activity or commercial gain

If the publication is distributed under the terms of Article $25 \mathrm{fa}$ of the Dutch Copyright Act, indicated by the "Taverne" license above, 
Pediatric interhospital intensive care transport in The Netherlands:

Current situation and future perspectives 
Copyright (C) 2004 G.D. Vos. All rights reserved ISBN 90-5681-188-6

Author / lay-out G.D. Vos

Cover illustration Luuk Aarts

Productions Unigraphic, University Maastricht 


\title{
Pediatric interhospital intensive care transport in The Netherlands: \\ Current situation and future perspectives
}

\author{
PROEFSCHRIFT \\ ter verkrijging van de graad van doctor \\ aan de Universiteit Maastricht, \\ op gezag van de Rector Magnificus \\ Prof. Mr. G.P.M.F. Mols, \\ volgens het besluit van het College van Decanen, \\ in het openbaar te verdedigen \\ op donderdag 5 februari 2004 om14.00 uur
}

door

Gijsbert Dirk Vos 


\section{Promotores}

Prof. dr. R.A.M.G. Donckerwolcke

Prof. dr. W.A. Buurman

Prof. dr. G. Ramsay

\section{Beoordelingscommissie}

Prof. dr. C.E. Blanco (voorzitter)

Prof. dr. E. Beuls

Prof. dr. E. Heineman

Dr. N.J.G. Jansen (Wilhelmina Kinderziekenhuis, UMC, Utrecht)

The study presented in this thesis is a research project of the division of pediatric intensive care, department of pediatrics, of the University Hospital Maastricht and was performed at the Nutrition and Toxicology Research Institute Maastricht (NUTRIM), University of Maastricht, The Netherlands. 
Aan Mieke, Koen, Daan en Eefke Aan mijn ouders Voor al die kinderen waarop dit proefschrift van toepassing is 


\section{Contents}

Chapter 1 Introduction.

Centralization of pediatric intensive care and pediatric intensive care transport: Review of the literature and the situation in The Netherlands.

Yearbook of Intensive Care and Emergency Medicine 2003; 791-799

Chapter 2 Comparison of interhospital pediatric intensive care transport accompanied by a specialist retrieval team with nontrained referral physicians in The Netherlands. Intensive Care Medicine, in press

Chapter 3 Problems in interhospital pediatric intensive care transport in The Netherlands: Results from a survey of general pediatricians.

Intensive Care Medicine 2003; 29:1555-1559

Chapter 4 Interhospital pediatric intensive care transport:

A novel mobile pediatric intensive care transport unit based on a standard ambulance trolley.

European Journal of Emergency Medicine 2003; 10:195-199

Chapter 5 Point-of-care technology: A portable whole blood analyzer 75 leads to therapeutically interventions during the interhospital transport of critically ill children. European Journal of Emergency Medicine, submitted

Chapter 6 General discussion and future perspectives.

Chapter 7 Summary

Hoofdstuk 7 Samenvatting

Curriculum vitae

Publications

Dankwoord 


\section{Introduction \\ Centralization of pediatric \\ intensive care and interhospital \\ pediatric intensive care \\ transport: \\ Review of the literature and the \\ situation in The Netherlands}

Vos GD, Ramsay G

Adapted from Yearbook of Intensive Care and Emergency Medicine 2003

Edited by J.-L. Vincent, Springer, pages 791-799 


\section{Introduction}

Recent developments in providing intensive care for children favor centralization of care in tertiary centers. The reason is the evidence that critically ill children show a better clinical outcome when treated in tertiary pediatric intensive care units than when treated in other pediatric centers[1-4]. Major problems hindering the transfer of children, requiring tertiary pediatric intensive care, to specialized centers are: 1) the lack of sufficient pediatric intensive care beds in tertiary centers, 2) the reluctance of physicians in general hospitals to refer these critically ill children and 3 ) the organization of safe transportation of these children on a regular basis. From the literature it is known that interhospital transport of critically ill children by non-trained personnel tends to be associated with a higher incidence of major complications than transport by specialized pediatric retrieval teams [5-8]. Specialized transport teams are able to produce a high degree of stabilization of the patient prior to and during transport [6, 7]. Specialized pediatric retrieval teams must provide all equipment and materials necessary for advanced life support and emergency treatment of children of all ages and body weights in order to bring the level of therapy and monitoring during the period of stabilization and transport as close as possible to that of pediatric intensive care units. It is generally accepted that instability of the patient and complications during transport are minimized by optimal resuscitation and stabilization prior to transport [9-12] and by avoiding interruptions in ventilation and monitoring en route [13].

\section{Centralization of pediatric intensive care}

Critically ill children show a wide variation in pathophysiology and occurrence of diseases according to age. Illness and pathophysiology differ from that of critically ill adults, and therefore require specialized skills, training and experience of the medical and nursing staff. The outcomes of children cared for in specialized tertiary pediatric intensive care units (PICU) is better compared to general intensive care units (ICU) in developed countries.

A prospective, blinded comparison of outcome and care study in the United States of America in 1991 [2] showed that the mortality of infants and children needing intensive care treated in non-tertiary centers was $10 \%$ higher than in tertiary centers (odds ratio 1.1) while their calculated pediatric risk of mortality (PRISM) was less than $5 \%$. The PRISM score is one of the generally accepted mortality risk prediction models for pediatric patients [14]. This score is based on 14 routinely measured clinical and laboratory parameters, with for each parameter an abnormal range. The most abnormal value in the first 24 hours 
following admission to the PICU contributes to this score. Every parameter, scored in the range of abnormal values, has a weighted contribution to the PRISM score (Table 1, page 12). In the more severe illness group (PRISM 5$30 \%$ ) observed mortality was $130 \%$ higher (odds ratio 2.3 ) in the group of patients treated in a non-tertiary center versus tertiary center, where in the most severe illness group (PRISM more than 30\%) the observed mortality was increased with $700 \%$ (odds ratio 8.0 , Table 2 ).

\section{Table 2}

Odds ratio's of the observed mortality of pediatric intensive care patients in non-tertiary intensive care units in comparison to tertiary centers (Pollack 1991)

$\begin{array}{lccc}\text { PRISM } & <5 \% & 5-30 \% & >30 \% \\ \text { Odds ratio } & 1.1 & 2.3 & 8.0\end{array}$

This study was performed in 3 tertiary and 71 nontertiary hospitals in Oregon and southwestern Washington State. Patients in tertiary facilities received more $(p<0.05)$ invasive (e.g., arterial catheters) and complex (e.g., mechanical ventilation) care, whereas patients in nontertiary facilities received more $(p<0.05)$ labor-intensive care (e.g., hourly vital signs). The authors concluded that if the care of the most seriously ill children is provided by tertiary pediatric intensive care units this could improve their chances of survival.

In a prospective comparison study [1] in Trent in the United Kingdom, with fragmented intensive care for children versus Victoria in Australia with highly organized tertiary pediatric intensive care the odds ratio for the risk of death was 2.09 adjusted for severity of illness (Table 3 ).

\begin{tabular}{|c|c|c|}
\hline \multicolumn{3}{|c|}{$\begin{array}{l}\text { Table } 3 \\
\text { Comparison of Trent (fragmented ICU care for pediatric patients) versus Victoria } \\
\text { (centralized pediatric intensive care) (Pearson 1997) }\end{array}$} \\
\hline & Trent & Victoria \\
\hline \multicolumn{3}{|l|}{ Population } \\
\hline Total (in millions) & 4.2 & 4.5 \\
\hline Under 16 years (in millions) & 0.833 & 1.011 \\
\hline \multicolumn{3}{|l|}{ Child ICU admissions } \\
\hline Number per year & 1014 & 1194 \\
\hline Per 1000 under 16 years & 1.22 & 1.18 \\
\hline Ventilated in first hour per 1000 under 16 years & 0.65 & 0.50 \\
\hline Mean length of stay (days) & 3.93 & 2.14 \\
\hline Child ICU days per 1000 under 16 years & 4.80 & 2.53 \\
\hline \multicolumn{3}{|l|}{ Mortality } \\
\hline Deaths (number and percentage) & $74 \quad(7.3 \%)$ & $60 \quad(5.0 \%)$ \\
\hline Expected deaths (number and percentage) & $42.3(4.2 \%)$ & $60.0(5.0 \%)$ \\
\hline
\end{tabular}




\section{Chapter 1}

\begin{tabular}{|c|c|c|c|}
\hline \multicolumn{4}{|c|}{ Pediatric Risk of Mortality (PRISM) Score (Pollack 1988) } \\
\hline \multirow[t]{2}{*}{ Variable } & \multicolumn{2}{|c|}{ Age restrictions and ranges } & \multirow[t]{2}{*}{ Points } \\
\hline & Infant & child & \\
\hline $\begin{array}{l}\text { Respiratory rate } \\
\text { (breaths/min }\end{array}$ & $\begin{array}{c}61-90 \\
\text { apnea, }>90\end{array}$ & $\begin{array}{c}51-70 \\
\text { apnea, > } 70\end{array}$ & $\begin{array}{l}1 \\
5\end{array}$ \\
\hline Heart rate (beats/min) & $<90,>160$ & $<80,>150$ & 4 \\
\hline \multirow[t]{2}{*}{$\begin{array}{l}\text { Systolic blood pressure } \\
(\mathrm{mmHg})\end{array}$} & $\begin{array}{c}130-160 \\
55-65 \\
>160 \\
40-54 \\
<40\end{array}$ & $\begin{array}{c}150-200 \\
65-75 \\
>200 \\
50-64 \\
<50\end{array}$ & $\begin{array}{l}2 \\
2 \\
6 \\
6 \\
7\end{array}$ \\
\hline & \multicolumn{2}{|c|}{ All ages } & \\
\hline Diastolic blood pressure & \multicolumn{2}{|c|}{$>110$} & 6 \\
\hline $\mathrm{PaO}_{2} / \mathrm{FiO}_{2}{ }^{\mathrm{a}}$ & \multicolumn{2}{|c|}{$\begin{array}{l}200-300 \\
<200\end{array}$} & $\begin{array}{l}2 \\
3\end{array}$ \\
\hline $\mathrm{PaCO}_{2}(\mathrm{mmHg})^{\mathrm{b}}$ & \multicolumn{2}{|c|}{$\begin{array}{l}51-65 \\
>65\end{array}$} & $\begin{array}{l}1 \\
5\end{array}$ \\
\hline Glasgow Coma Score $^{c}$ & \multicolumn{2}{|c|}{$<8$} & 6 \\
\hline Pupillary reactions & \multicolumn{2}{|c|}{$\begin{array}{l}\text { unequal or dilated } \\
\text { fixed and dilated }\end{array}$} & $\begin{array}{r}4 \\
10\end{array}$ \\
\hline Coagulation (APTT) & \multicolumn{2}{|c|}{$>1.5 \times$ control } & 2 \\
\hline Total bilirubin $(\mathrm{mmol} / \mathrm{l})^{d}$ & \multicolumn{2}{|c|}{$>60$} & 6 \\
\hline Potassium (mmol/l) & $\begin{array}{c}3.0-3.5 \\
<3.0\end{array}$ & $\begin{array}{l}6.5-7.5 \\
>7.5\end{array}$ & $\begin{array}{l}1 \\
5\end{array}$ \\
\hline Calcium (mmol/l) & $\begin{array}{l}1.75-2.00 \\
<1.75\end{array}$ & $\begin{array}{l}3.00-3.75 \\
>3.75\end{array}$ & $\begin{array}{l}2 \\
6\end{array}$ \\
\hline Glucose (mmol/l) & $\begin{array}{l}2.2-3.3 \\
<2.2\end{array}$ & $\begin{array}{l}13.5-22.5 \\
>22.5\end{array}$ & $\begin{array}{l}4 \\
8\end{array}$ \\
\hline Bicarbonate $(\mathrm{mmol} / \mathrm{l})$ & $<16$ & $>32$ & 3 \\
\hline \multicolumn{4}{|c|}{$\begin{array}{l}\text { a Cannot be assessed in patients with intracardiac shunts or chronic respiratory insufficiency; } \\
\text { requires arterial bloodgas sampling } \\
\text { b May be assessed with capillary blood gases } \\
\text { c Assessed only when there is known or suspected CNS dysfunction; } \\
\text { cannot be assessed in patients within } 24 \text { hrs after sedation, paralysis, anesthesia etc. } \\
{ }^{d} \text { Not to be assessed in neonates (< } 4 \text { weeks old). }\end{array}$} \\
\hline
\end{tabular}

The overall risk in mortality can be predicted by a logistic regression equation.

$r=$ sum of the weighted contributions of all abnormal parameters.

$R$ is calculated from the $r$ score, age and operative state and their covariates from the logistic regression.

$R=(0.207 \times r)+(-0.005 x$ age in month $)+(-0.433 \times$ operative status $(0$ or 1$)+(-4.782)$

The probability of PICU death can be subsequently predicted by $P=\exp (R) /(1+\exp (R))$ 
The calculated excess death of pediatric patients in the ICU was $42.8 \%$ for Trent in comparison to Victoria. Of all children that died in Trent during the study period the excess death rate due to fragmented care was $11.1 \%$. It is not mentioned in the manuscript if the study was blinded. The authors made the interpretation that for the whole UK there was an excess death of 453 pediatric patients annually due to the fragmented care for pediatric intensive care patients. Further they stated that, if the ratio of pediatric intensive care units to the population of children were the same in the UK as in Victoria, there would only be the necessity for 12 pediatric intensive care units in the country. Their findings suggest that substantial reduction in mortality could be achieved if every child in the UK who needed endotracheal intubation for more than 12-24 hours were admitted to one of the 12 largest specialist pediatric intensive care units.

The same result, of better outcome of care for critically ill children treated in tertiary centers was shown in a Dutch study [3]. In this prospective comparison study the authors concluded that the relative low mortality rates of high-risk patients in tertiary care centers supports concentration of pediatric intensive care for these patients (Table 4). However the number of patients in the nontertiary care centers was very low, impairing the comparison.

\begin{tabular}{|c|c|c|c|}
\hline \multicolumn{4}{|c|}{ Effectiveness of care in tertiary and nontertiary centers (Gemke 1995) } \\
\hline Mortality risk group & Low (\#15\%) & High (> 15\%) & Total \\
\hline \multicolumn{4}{|l|}{ Tertiary care } \\
\hline Survivors & 706 & 68 & 774 \\
\hline Observed / expected deaths & $25 / 19.9$ & $41 / 48.2$ & $66 / 68.1$ \\
\hline \multicolumn{4}{|l|}{ Nontertiary care } \\
\hline Survivors & 210 & 4 & 214 \\
\hline Observed / expected deaths & $3 / 3.1$ & $6 / 4.2$ & $9 / 7.3$ \\
\hline Odds ratio & 0.49 & 2.41 & \\
\hline
\end{tabular}

With these and other studies [1-4] showing that critically ill children have a better outcome if treated in tertiary pediatric intensive care units rather than in non-tertiary pediatric centers, the provision of intensive care for children has become centralized in tertiary centers in most of the developed countries. In the United States the Society of Critical Care Medicine (SCCM) and the American Academy of Pediatrics (AAP) have developed guidelines to provide a reference for the regionalization of services for critically ill or injured children [15], and developed admission and discharge policies for critically ill children [16], and the transfer of critically ill patients [17]. In Great Britain the provision of intensive care for children is based on a policy framework, that sets out a strategy for 


\section{Chapter 1}

developing and integrating the service for critically ill children within a geographical area [18].

The centralization of intensive care and in particular pediatric intensive care leads to the possibility of better management and organization of these units. Outcome and quality of care can be influenced by the improvement of management and organization in the care for critically ill patients, whether adult, pediatric or neonatal. This is shown by many studies in which it is also shown that efficiency in the use of intensive care resources increases and mortality is reduced when full-time intensivists are employed [19-24]. There were some critics that were against the transfer of all critically ill pediatric patients. They stated that the Trent versus Victoria study was reflecting the general underprovision of intensive care in the United Kingdom, rather than improvement of care by centralization [25]. However the admission rate was 1.2 per 1000 children in both places but crude mortality was 45\% higher in Trent. This difference persisted after adjustment for severity of illness. Moreover, it is not important whether outcome by centralization is better due to the referral of critically ill children to large specialist pediatric intensive care units staffed by full time pediatric intensivists and nurses, or to better provision of intensive care. Goldhill and Withington also stated that many children, particularly the older ones have straightforward intensive care problems and depend on the same equipment and principles that are used in general intensive care. In their opinion over-centralization has many disadvantages such as reducing skill levels in local hospitals, the breakdown of family centered care, and additional costs. However, this last argument must not be the key to reverse the process of regionalization, but it has to be the key to optimize the training of physicians in community hospitals in advanced pediatric life support, to ensure the most appropriate treatment of critically ill children following admission and in the first period waiting for their transfer.

All above-mentioned studies were performed in developed countries. In the developing countries the access to health care facilities is limited especially for intensive care. Since resources for health care in these countries are scarce the investment in centralization of pediatric intensive care will not have high priority.

General criteria for the transfer of critically ill infants and children to tertiary centers are given by Pollack [2, 16] and the American Academy of Pediatrics [16]. In general these criteria can be summarized as the need for artificial ventilation for a period longer than 24 hours, or more than one organ dysfunction. 
In conclusion, there is substantial evidence (level of evidence 3 and 4 ) that critically ill infants and children have a better outcome with less morbidity and mortality when treated in tertiary facility pediatric intensive care units in comparison to treatment in non-tertiary hospitals.

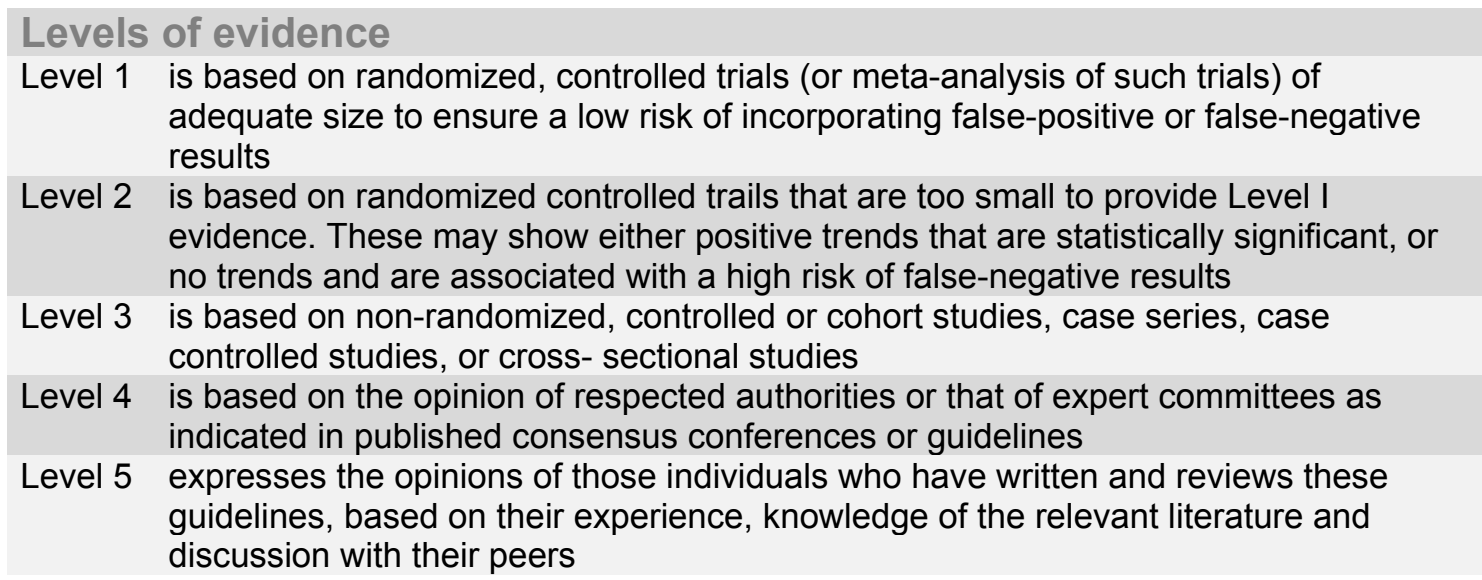

\section{Centralization of pediatric intensive care in The Netherlands}

In The Netherlands pediatric intensive care is centralized in the eight university medical centers. There is a concentration of these centers in the western part of The Netherlands, with the highest population density.

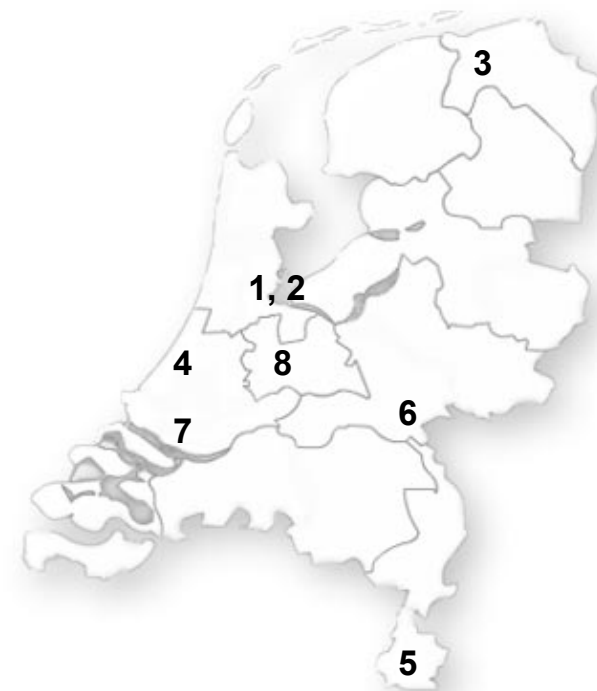

1 Amsterdam

Emma Children's Hospital, University Medical Center

2 Amsterdam

VU University Medical Center

3 Groningen

University Medical Center

4 Leiden

University Medical Center

5 Maastricht

University Medical Center

6 Nijmegen

University Medical Center

7 Rotterdam

Sophia Children's Hospital, Erasmus Medical Center

8 Utrecht

Wilhelmina Children's Hospital, University Medical Center 


\section{Chapter 1}

In July 2003 there were 16.192 million inhabitants in The Netherlands, of which 3.969 million in the age from $0-19$ years (source Statistics Netherlands, www.cbs.nl).

In the year 2000 the mean number of operational pediatric intensive care beds was 78.7, with 12.3 out of 91 beds being closed due to shortage of manpower. Between April $1^{\text {st }} 2000$ and March $31^{\text {st }} 2001$ in total 4038 children were admitted to one of the PICU's (Table 5). The number of nursing-days was 26.385 with a mean length of stay on the PICU of 6.53 days. During this period there were 408 pediatric admissions on the Intensive Care Unit for adults in the university medical centers, 525 pediatric admissions on the Intensive Care Unit for adults in the community hospitals and 202 pediatric admissions on high care pediatric facilities in community hospitals [26]. In total there were 5173 intensive care admissions of children from a population of 3.9 million. This results in 1.3 annual admissions per 1000 infants, children and adolescents. This is slightly higher than in the Trent versus Victoria study (1.2 / 1000) [2].

The admissions to the adult Intensive Care Units in the University Medical Centers were mainly because in several centers children are monitored and treated in the early post-operative period after cardio-thoracic surgery on the adult cardio-thoracic intensive care unit. In one center this included also children undergoing liver transplant. Only a few children were admitted to the adult ICU of the university medical centers because there was no intensive care bed available on the PICU in that center. The admissions on the ICU in the community hospitals were mainly due to the lack of free PICU beds available, and partly due to the reluctance of physicians in community hospitals to transfer these critically ill children. This last reason was the main cause for the admissions on the high care facilities for pediatric patients in community hospitals, although these patients met the criteria for transfer.

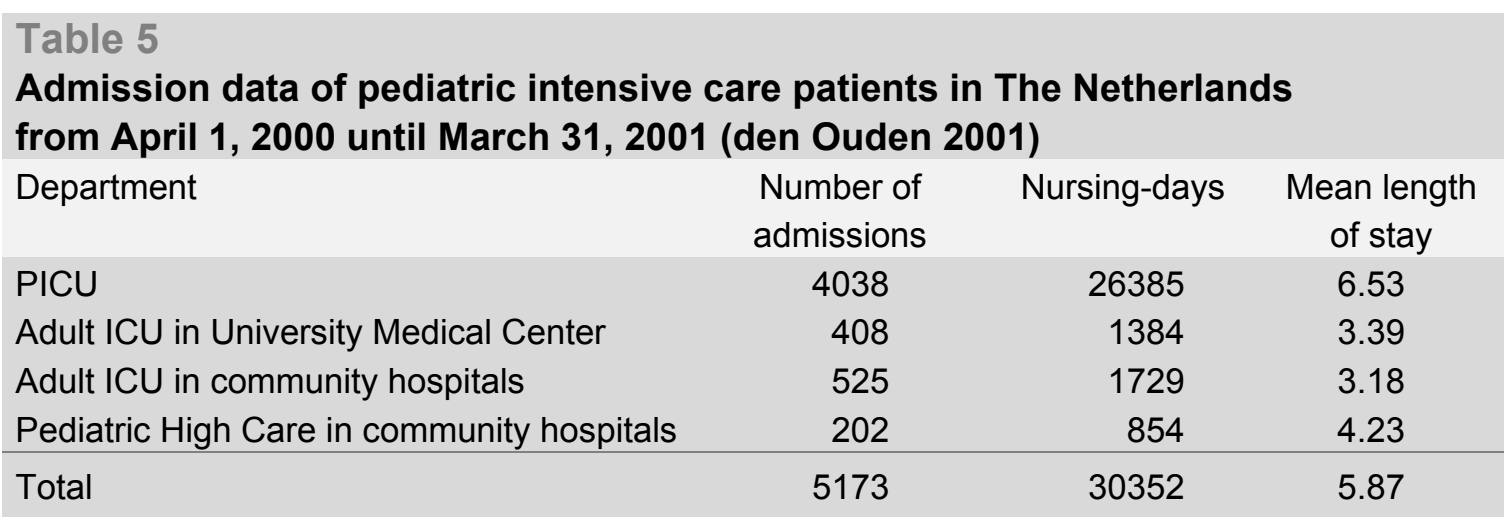

In the year of this survey there was no intensive care bed available for 909 infants and children in the regional tertiary facility. Nearly $50 \%$ of these 
shortages were reported in the months January and December, when there was a high incidence of infants with respiratory failure due to respiratory syncytial virus (RSV).

Eventually these patients were transferred to a PICU in another region (59\%), a neonatal intensive care in the region $(4 \%)$, the ICU in the referring hospital $(3 \%)$, or to a PICU abroad $(4 \%)$. In $23 \%$ of the cases the patient stayed on the general pediatric ward of the referring hospital. In $7 \%$ it concerned patients scheduled for post-operative admission for which the operation needed to be postponed.

From these data the Inspector of Healthcare calculated the need for PICU beds in The Netherlands to be at least 102, assuming that all children that meet the criteria for transfer will be actually transferred to a tertiary facility center.

The numbers of PICU beds and admissions from the survey of the Inspector of Health Care in The Netherlands differ from those in a recent European survey of pediatric intensive care units [26, 27]. There are however many points of criticism to make on this European survey and it may not be representative and not reflect the genuine organizational and structural features, as for example shown for the Spanish situation [28, 29]. Also the data on the situation in The Netherlands according to this survey (11 hospitals with PICU, average size 18 , average number of admissions 609) is not correct. The last data (2001) of the number of PICU beds and admissions in The Netherlands by the Society of University Medical Centers (VAZ), the sector organization representing the providers of care insurance in The Netherlands $(\mathrm{ZN})$ and the Dutch Society of Pediatrics show that the data of PICU beds and admissions from the survey of the Inspector of Health Care in The Netherlands [26] reflect the Dutch situation more accurately than the European survey. In 2001 there was a slight increase of operational PICU beds by 5.7 beds, there were 3911 admissions whereas in 1170 cases there was no PICU bed available. According to these data the estimated number of PICU beds in The Netherlands should be at least 129, which is 27 beds more than the calculation in 2000. Annual fluctuations and the increasing demand of pediatric intensive care beds are responsible for the differences.

In 2002 the Ministry of Healthcare in The Netherlands formulated a policy framework towards the centralization of pediatric intensive care and the finances for its execution [30]. This policy is supported by the knowledge that pediatric intensive care is a low volume, high cost specialty, which demands a special level of skills and training of medical and nursing staff and the availability of specialist equipment. Without centralization there is a risk of reduced quality and lack of continuity of care for critically ill children. The tertiary facilities of pediatric intensive care have a full range of tertiary pediatric services 


\section{Chapter 1}

with a sufficient throughput to maintain staff expertise and act as educational and training centers. These centers will be responsible for data collection, audit, and development of joint protocols with the community hospitals within the region. The process of centralization increasingly demands the interhospital transport of critically ill infants and children, and these transports have to be organized. In the policy framework it is stated that the tertiary facility centers are likewise responsible to introduce and maintain a 24-hour interhospital transport service for the region.

The criteria for the transfer of critically ill infants and children are adopted from the American Academy of Pediatrics [16] by the Dutch Association of Pediatrics, with the adjustment that all infants needing endotracheal intubation are eligible for transfer independent of the expected length of intubation.

The reasons for transfer are heterogeneous as reported in the literature $[5,6]$ and in the report of the Dutch Inspector of Health Care [26]. Respiratory insufficiency is the primary indication for transfer in about one half of the cases. Most of these patients are suffering from RSV infection, while also upper airway obstructions and pneumonia are a frequent cause of respiratory insufficiency. Circulatory insufficiency also turns out to be an important primary indication for transfer. Septic shock, especially meningococcal septic shock is the most frequent diagnosis in this group. Within the group of patients with neurological disturbances the most frequent diagnosis is status epilepticus.

In conclusion, progression has been made in The Netherlands towards the centralization of pediatric intensive care, although there is still a substantial number of patients who meet the criteria for transfer, but are not referred. This situation might improve if more PICU beds are available, the criteria for transfer are pursued and the interhospital transport of these critically ill children is well organized. 


\section{Pediatric intensive care transport}

The trend towards centralization of pediatric intensive care leads to a growing number of interhospital pediatric intensive care transports. Since it concerns critically ill children the care during the transfer should be as close as possible at the level of the tertiary pediatric intensive care. Intensive care patients have derangement of vital organs and physiology and they tend to become unstable on movement. The principles of safe transfer of these patients demand experienced staff, appropriate equipment and extensive monitoring, careful stabilization prior to the transport and full view of and access to the patient and equipment.

\section{Accompanying personnel}

Most studies on accompanying personnel, whether professional transport teams or transports accompanied by non-experienced specialists, are case studies without comparison of both groups in one study or without retrospective comparison [5, 6, 31].

An observational study of 56 critically ill children transferred from a community hospital to a tertiary facility center and accompanied by inexperienced staff [5] showed a high incidence of serious and life threatening adverse events during transport. In 14 transports (25\%) there were no adverse events, in 42 (75\%) there were one or more adverse events. In total there were 95 adverse events during these transports, 67 serious and 28 critical (Table 6). Inadequate circulatory and ventilatory support, inadequate monitoring, equipment failures, and drug errors were common. Children who subsequently died were more likely to have had complicated transfers than those who survived. The authors concluded that to reduce unsatisfactory care during transfer, it is necessary to establish dedicated and specifically trained pediatric transport teams.

\section{Table 6}

Number of adverse events during transport of critically ill children accompanied by inexperienced staff (Barry 1994)

\begin{tabular}{lcc} 
No adverse event & Number & $\begin{array}{c}\text { Percentage of } \\
\text { transports }\end{array}$ \\
1 adverse event per transport & 14 & 25.0 \\
2 adverse events per transport & 17 & 30.4 \\
3 or more adverse events per transport & 14 & 25.0 \\
\hline Total & 11 & 19.6 \\
\hline
\end{tabular}




\section{Chapter 1}

The impact of a specialized pediatric retrieval team on morbidity and severity of illness during interhospital transfer was studied in 51 critically ill children transferred to a pediatric intensive care tertiary center [6]. Two patients (4\%) had preventable deterioration during transfer. No equipment related adverse events were reported and severity of illness decreased during the period of stabilization by the retrieval team in the referring hospital before transport, and during transport. This was shown by the pediatric risk of mortality scores before and after the transfer (Table 7).

\section{Table 7}

Median scores for pediatric risk of mortality (PRISM) (Britto 1995)

$\begin{array}{cccc}\begin{array}{c}\text { No }(\%) \text { of } \\ \text { patients }\end{array} & \begin{array}{c}\text { Median (range) PRISM } \\ \text { on admission }\end{array} & \begin{array}{c}\text { Median (range) PRISM } \\ \text { before retrieval }\end{array} & \begin{array}{c}\text { Median (range) PRISM } \\ \text { after retrieval }\end{array} \\ 51 & 14(1-45) & 11(0-40) & 8(0-23)\end{array}$

Difference between PRISM on admission and before retrieval $p<0.001$

Difference between PRISM before retrieval and after retrieval $p<0.001$

The time between the first call for referral and the delivery of specialized care by the retrieval team at the bedside of the patient in the referring hospital was 45225 (median 100) minutes. The conclusion of the authors was that a specialized retrieval team could rapidly deliver intensive care to critically ill children awaiting transfer and that the transfer could be done with minimal morbidity and mortality related to the transport.

Other studies have also shown that specialized pediatric intensive care teams can deliver rapid and effective care to children requiring interhospital transfer [32-34].

A retrospective study in adult critically ill patients described the results from 2 years experience of interhospital transport via a ground critical care transport service [31]. This mobile intensive care unit was equipped and staffed to nearly create the intensive care environment. Staffing included a physician, nurse, respiratory therapist, and driver, all with extensive critical care experience. During this period 39 critically ill patients were transferred, all with extremely severe respiratory failure (mean PEEP 15.9, mean $\mathrm{FiO}_{2}$ requirement of 0.93 , and mean $\mathrm{PaO}_{2} / \mathrm{FiO}_{2}$ ratio of 59.8). The predicted mortality rate was 68 to $100 \%$, the actual subsequent hospital mortality rate was $43 \%$. One patient died during the transfer and one episode of transient hypotension was reported. The authors concluded that, when a mobile intensive care unit is properly staffed and equipped and patient stabilization is achieved before transfer, severely ill patients with respiratory failure could be transferred safely.

In a prospective study of pediatric intensive care transport morbidity was compared between two types of transport systems in 141 interhospital 
transports: specialized tertiary center-based vs. nonspecialized, referring hospital-based. The specialized team consisted of a pediatric resident, pediatric intensive care nurse, and a pediatric respiratory therapist. The nonspecialized team consisted of personnel from the referring hospital. The two centers were similar in size and patient mix, with referral areas of similar population and rural/urban ratio. Intensive care-related adverse events occurred in one (2\%) of 49 transports by the specialized team and $18(20 \%)$ of 92 transports by nonspecialized personnel $(p<0.05)$. Physiologic deterioration was similar in the two groups occurring in five $(11 \%)$ of 47 specialized team transports and 11 $(12 \%)$ of 92 transports by the nonspecialized team [32].

Recently one case-control study of the interhospital transport of adult intensive care patients has been published [7]. In this study it was shown that the use of a specialist transfer team may significantly improve the acute physiology of critically ill patients and may reduce early mortality in ICU. In this study however the ambulance personnel accompanied the control group during the transfer.

In a retrospective study of 331 consecutive children with meningococcal disease and transferred from a community hospital to a tertiary facility with pediatric intensive care a significant improvement in outcome was shown (Table 8). The authors explain the better outcome by improvements in initial management at the referring hospitals, the use of a mobile intensive care service, and the centralization of care in a specialist unit [8]. A senior pediatric intensivist and a senior pediatric intensive care nurse led the mobile intensive care service.

\section{Table 8}

Number of admissions, annual case fatality rates predicted by PRISM and actual annual case fatility (Booy 2001)

$\begin{array}{lcrrrr} & 1992 / 93 & 1994 & 1995 & 1996 & 1997 \\ \text { Number of admissions } & 40 & 39 & 62 & 72 & 110 \\ \text { Predicted death rate by PRISM (\%) } & 32 & 32 & 25 & 27 & 34 \\ \text { Observed death rate (\%) } & 23 & 13 & 12 & 11 & 2\end{array}$

Complications of intensive care transport in general and especially pediatric intensive care transport have been described in the literature with a variation of complications from 5 tot $75 \%[5,7,13,35-39]$. There is a difference in the definition of complications during transport of critically ill patient between these reports and there is no uniformity according to the time of onset of these complications (before, during or directly after transport). The majority of complications given in the literature are a decrease of $\mathrm{PaO}_{2} / \mathrm{FiO}_{2}$ ratio, variation of end-tidal $\mathrm{CO}_{2}$ and blood pressure. 


\section{Chapter 1}

Mortality during transport is rare and the cause of death, whether technical failure, incorrect decision for transfer or insufficient training and expertise is not given. One case control study in adult intensive care transport reveals a significantly higher mortality rate in transported patients compared to non transported patients in a matched population for severity of illness (APACHE-II), $51 \%$ verses $23 \%(p<0.01)[37]$.

There is no good scoring system to determine, before the interhospital transfer, the requirement for intensive care and the performance of major interventions in the pretransport stabilization period and during the transport. The pretransport PRISM score underestimates these requirements and should not be used as a triage tool for pediatric interhospital transport [40-42].

In a survey of anesthetists in the United Kingdom 74 respondents reported adequate personal injury indemnity was provided and 81 were unsure as to the level of cover provided [43]. Hospitals allow apparently their personnel to transfer patients without adequate professional indemnity or personal insurance.

In conclusion, most of the studies (all level of evidence 3 and 4 ) establish that a professional team should accompany interhospital pediatric intensive care transport. Severity of illness scoring systems perform inadequately when used to predict risk of complications during transport, since they are of little use in the management of an individual patient. Specialist retrieval teams irrespective of the child's severity of illness scores should transfer all critically ill children. The members of such a team may differ in various countries but should include a medical specialist and/or a nurse, both trained in pediatric intensive care and in the transport of critically ill patients.

\section{Accompanying personnel in The Netherlands}

In The Netherlands there are no guidelines for pediatric interhospital intensive care transport, nor a commitment that specialist retrieval teams will accompany all transports. Two out of the eight tertiary PICU's have well organized and almost continuously accessible transport facilities. The other six centers only perform transports in specific cases, depending on the severity of the patient's condition and the availability of personnel in the PICU. This has resulted in a situation whereby specialist retrieval teams accompany about one-third of the pediatric intensive care transports. The referring specialists, who are not trained in pediatric intensive care and pediatric intensive care transport, accompany the other two-thirds. The annual incidence of interhospital transport of critically ill children is about 1000 transports. In contrast to the interhospital transport of 
critically ill children these transports are well-organized in neonates in The Netherlands. Specialist retrieval teams accompany all interhospital transports of neonates in The Netherlands.

Although there is evidence, that specialist retrieval teams have a better outcome in transport of critically ill patients regarding mortality, morbidity and complications, and despite the guidelines for interhospital intensive care transport available in the literature, two thirds of all critically ill children in The Netherlands are still accompanied during the interhospital transports by the referring physicians.

The impact of the unavailability in The Netherlands of pediatric intensive care retrieval teams in two thirds of all interhospital transports on the outcome of patients, stabilization prior and during the transport, and transport related complications needed to be studied. It is of utmost importance to assess the influence of current transport systems not only on outcome of the patient, but also on the well-being of the general pediatrician who has to accompany these critically ill children during their transport, without adequate training and equipment.

\section{Equipment and materials}

The goal of specialist retrieval teams is to establish specialized intensive care at the bedside of the patient as soon as the retrieval team arrives at the referring hospital. The level of therapy, interventions and monitoring should be as close as possible to the care given on the PICU of a tertiary facility center. Although there are guidelines for interhospital intensive care transport (Table 9) there is little literature data available on aspects of monitoring, choice of ventilators, other equipment and materials in general and specifically for pediatric transport. Guidelines are drawn up by common sense and according the standards on the intensive care.

There are a few studies showing that the equipment and the materials available during transports accompanied by non-trained specialists appear to be nonstandardized and not matching the criteria for the monitoring and treatment as formulated in the guidelines during transfer of critically ill patients [5, 43]. 


\section{Chapter 1}

\section{Table 9}

Minimum equipment for interhospital intensive care transport according to the Guidelines for the Transfer of Critically III Patients (Society of Critical Care Medicine 1993) [13]

Monitoring, minimal requirements

Continuous ECG, continuous respiration, continuous pulse oximetry, intermittent blood pressure,

Monitoring on indication

Continuous blood pressure, central venous pressure, pulmonary artery pressure, intracranial pressure,

intubated patients receiving mechanical ventilation,

end tidal dioxide

airway pressure

disconnection alarm

\section{Airway and ventilatory management}

Resuscitation bag and mask of proper size and fit for the patient, oral airways, laryngoscopes, and endotracheal tubes of proper size for the patient, oxygen source with quantity sufficient to meet the patient's anticipated consumption with at least one hour reserve in addition, suction apparatus and catheters

\section{Circulatory management}

Cardiac monitor/defibrillator, blood pressure cuff, materials for venous access (cannulas), materials for intravenous therapy (solutions, tubing, needles and syringes, and devices for regulation of continuous intravenous infusions

\section{Medications}

Drugs for advanced cardiac resuscitation, drugs for the management of acute physiologic derangements, drugs for the specific needs of that patient (e.g., sedatives, antibiotics)

\section{Communication}

Equipment to allow contact between the transporting vehicle and both the referring and receiving hospitals

\section{Documentation}

Medical record documenting the patient's status and management during the transport 


\section{Mechanical ventilation}

During interhospital transports of infants and small children (less than $15 \mathrm{~kg}$ ), especially accompanied by non-trained specialists, mechanical ventilation is mostly done by hand-bagging, because there is generally no ventilator available during transport suitable for these patients. In older children and adults mechanical ventilation is either done by hand-bagging, because of lack of experience with the ventilator present during transport, or by the ventilator present in the ground ambulance.

Manual ventilation during transport however results in greater fluctuation of specialized ventilatory parameters from an established baseline than does the use of a transport ventilator. In a prospective, randomized study of 49 pediatric postoperative heart patients who required transport while still intubated, there was a statistical significant greater amount of variation in ventilation during transport with manual ventilation as opposed to mechanical ventilation, according to end tidal $\mathrm{CO}_{2}$ [13].

In another prospective, randomized study comparing manual ventilation with mechanical ventilation during intra-hospital transport resulted in a marked respiratory alkalosis compared with ventilation provided by a transport ventilator (pH 7.39 versus 7.51 and $\mathrm{PaCO}_{2} 39$ versus 30 torr). Oxygenation remained stable with both methods in this study and no patients suffered hemodynamic instability [44]. Deterioration in $\mathrm{PaO}_{2} / \mathrm{FiO}_{2}$ ratio in manually ventilated patients compared to mechanically ventilated patients was however shown in a prospective, randomized study of 22 intra-hospital transports. The mean respiratory rate was higher in the first group, and there was a significantly larger variation of mean tidal volume $(p<0.05)$ and positive end-expiratory pressure $(p<0.001)$.

Considering these data the use of a ventilator is recommended in the case of patients, who require mechanical ventilation, and have to be transported either intra-hospital or interhospital. It is strongly advised not to use manual ventilation by hand bagging unless no other option is available. In situations were the use of manual ventilation is necessary this has to be done by skilled personnel and preferably guided by end-tidal $\mathrm{CO}_{2}$ measurement.

The choice of which ventilator to use depends on the characteristics of the patient population to be transported and the transport distances. The advantages of a transport ventilator is that these ventilators are constructed for transports and tend to be resistant to vibration and falling from 0.75 meter onto a hard surface. Also radio frequencies do not interfere with these ventilators and they are lighter. On the other hand the ventilators specially developed for transport can not perform the same sophisticated techniques of ventilation, as do ventilators developed for the intensive care unit. They also lack the 


\section{Chapter 1}

possibility of use in all pediatric intensive care patients ranging from 2 kilogram to adult weight. They have insufficient monitor and alarm functions for tidal volumes and airway pressures. In one type of transport ventilator it was shown that triggering became more difficult with high PEEP levels, a higher ventilator setting was necessary than with a ventilator on the ICU, and peak inspiratory pressures were higher in the transport ventilator than in the ICU ventilator with the same tidal volumes [45].

The battery duration of transport ventilators differs greatly and is affected by control settings, lung impedance and ventilator characteristics, and may be shorter than reported in the operator's manual [46].

The ventilators used in the intensive care unit are not designed for transport use where the operational stress may be considerable. They are also not guaranteed in the vicinity of operating radio's and mobile phones [47]. The use of a ventilator designed essentially for static use may have medico-legal implications in case there is a ventilator-related complication during transport.

However the advantages of these ventilators with a wide range of ventilatory settings, reliable and extensive monitoring and alarm functions, the possible use in all pediatric patients, and the familiarity of the retrieval team of the PICU with these ventilators compensate for the disadvantages.

By careful handling and monitoring at all stages of transport ventilators designed for the intensive care may be safe, especially the new generation of these ventilators (like the servo-i, Siemens) that are also adapted for transport. Before purchasing a ventilator for the transport of critically ill patients the user must consider the purpose of the device, the patient population to be ventilated, and the capabilities of the individual devices.

\section{Monitoring}

Monitoring during transport should be comparable to that on the PICU with similar vital function monitoring and with similar alarm functions. During transport, the minimal requirement for monitoring is ECG, respiratory rate, pulse oximetry and non-invasive blood pressure. In most transports invasive blood pressure, temperature and capnography measurement is additionally required. Maintaining the end-tidal $\mathrm{CO}_{2}$ constant and, in patients with an indication for mild hyperventilation, between strict levels is of importance to critically ill patients. Hypercapnia might raise the intracranial pressure especially in neurotrauma patients, patients with meningitis, and in cases of posthypoxic encephalopathy. It may also increase pulmonary vascular resistance in patients tending to pulmonary hypertension. Hypocapnia may cause a decrease in 
cerebral blood flow. Unintentional hyperventilation and hypoventilation occurs during transport in manually ventilated patients [13, 43, 44, 48].

Verifying endotracheal tube placement in patients directly after and during the whole period of endotracheal intubation with end-tidal capnography is simple and safe. Therefore some authors suggest to use end-tidal capnography as a sixth vital sign in trauma patients in addition to heart rate, blood pressure, respiration rate, blood oxygen saturation and temperature [49].

In the intensive care setting diagnoses are frequently made and therapeutic interventions performed as a result of laboratory blood results. In interhospital transports however point-of-care blood testing is rarely used. Point-of-care blood testing might be of importance during transport. The availability of faster test results may expedite diagnosis and the initiation of treatment, and may have a positive impact on the care of critically ill patients [50-53]. Point-of-care testing reduces the time of decision making on patient managements that were dependent on the results of blood tests and reduces the time of changes in treatment for which timing is considered to be critical. Portable point-of-care blood analyzers have been used in pediatric interhospital transport and helicopter transport [54, 55], but only related to blood gases. The use of more extensive blood results than just blood gas analysis might be of utmost importance during transport and have to be studied.

\section{Other equipment and materials}

With the availability of both oxygen and air during transport it is possible to ventilate the patients with inspiratory oxygen fractions ranging from 0.21 to 1.0 . For oxygen and air, but also for battery capacities, infusion fluids and medications the recommendations are that they have to be sufficient for the worse case scenario. Planning the transport carefully is of utmost importance. Recommendation in one of the publications is therefore:

"Closely consider all drugs you could reasonably need, calculate the transport time, including loading and unloading procedures, and the maximum quantities of drugs and oxygen needed - then double it, and add some!" [47].

An extensive list of equipment and materials is given in table 10 (page 28).

Although the indication for electro shock therapy in children is rare, a defibrillator should be available. 


\section{Chapter 1}

\section{Table 10}

Recommended equipment and materials for pediatric interhospital intensive care transport

\section{Monitoring}

ECG, respiratory rate, pulse oximetry, temperature,

blood pressure non-invasive (cuffs neonatal, infant, child, adult), blood pressure invasive, capnography, point-of care blood testing

Defibrillator

5-400 J capacity with pediatric and adult paddles

\section{Airway management}

Laryngoscope with blades Miller 0-1 and Macintosh 1-4, Magill forceps (pediatric and adult), endotracheal tubes (uncuffed 2.0-6.0 and cuffed 5.0-8.0), endotracheal tube stylettes, oral airways $0-5$, suction unit and suction catheters, stethoscope,

\section{Ventilatory management}

Chest tubes and Heimlich valve, nebulizer, oxygen delivery devices (nasal cannulas, oxygen masks), artificial huminifider, resuscitation bags (child and adult),

PEEP valve, face masks (infant, child, adult), mechanical ventilator (neonatal, pediatric, adult)

\section{Gas supplies}

Oxygen and air, with pre and post pressure regulator manometer, flowmeter $-15 \mathrm{~L} / \mathrm{min}$, plug-ins for oxygen and air in ambulance and referring hospital

\section{Fluid management}

Intravenous cannulas, intra-osseous needles, central venous lines, infusion pumps, fluids (normal saline, $5 \%$ dextrose),

tubing, needles, syringes

\section{Medication}

\section{Pulmonary:}

Bronchodilators aerosol, salbutamol for iv, corticosteroids

Circulatory:

Adenosine, atropine, calcium chloride, diuretics, dobutamine, dopamine, epinephrine, norepinephrine, amiodarone, lidocaine, sodium bicarbonate, vasodilators

Neurologic:

Anticonvulsant, mannitol, muscle relaxants, naloxone, opiate, sedative

Other:

Antibiotics, clemastine, colloids, $50 \%$ dextrose, potassium, medication for all possible derangement

\section{Electrical power}

Plug-in connection in ambulance and referring hospital

\section{Other materials}

Adhesive tape, arterial line maintenance system, nasogastric tubes $(6,8,10,12 \mathrm{Fr})$, urinary bladder catheters (infant, child, adult), scissors, alcohol wipes, flashlight, resuscitation chard, patient chard, communication equipment 


\section{The interhospital transport unit}

An interhospital transport unit containing all equipment and materials required for transport, including the ventilator and gas supplies is essential, with the precondition that these should be readily accessible with optimal view on the patient and the equipment. For neonates mobile incubators have been developed for intra-hospital and interhospital transport and improved over the last decades. Despite these ongoing improvements there is still concern about vibration, noise, and acceleration and deceleration forces during the transport of neonates [56-59], and about the fixation of the patients. For pediatric and adult intensive care transport there is little literature about the development of transport units, especially units that contain all the equipment mentioned above. Mobile Intensive Care Units (MICU's) have been described for use in ambulances, airplanes and helicopters for the transport of adult patients [60-64], but they are not available on a commercial basis. Therefore the development of a pediatric intensive care transport unit based on a standard ambulance trolley was of utmost importance. 


\section{Chapter 1}

\section{Summary}

There is substantial evidence that critically ill infants and children have a better outcome when treated in tertiary facility PICU's compared to treatment on an ICU of a community hospital. Pediatric intensive care is a low volume, high cost specialty, demanding specially skilled medical and nursing staff and specialist equipment. Although in the Dutch situation the centralization is still not optimal, progress has been made during the last decade. Lack of PICU beds and reluctance to transfer children meeting the criteria for referral are the main reasons that optimal centralization has not yet been achieved.

The benefit of the centralization of the care of critically ill infants and children in tertiary pediatric intensive care units can only be achieved if the risks of the transfer are minimized. Professional specialist retrieval teams deliver transport care with better stabilization, less complications and with better outcome in comparison to transports accompanied by referring specialists not trained in intensive care and intensive care transport. Successful regionalization of pediatric intensive care depends therefore on an effective and responsive infrastructure for transporting critically ill children. The infrastructure must be developed around the needs of the patients and the referring hospital. During interhospital pediatric intensive care transport the level of treatment and monitoring should be as close as possible to the level on the PICU. The necessity for fully-fledged professional interhospital pediatric transport facilities is evident from the insufficient level of care during transports accompanied by non-trained specialists, which lead to a high incidence of serious and critical complications during these transports. In The Netherlands referring specialists still have to accompany critically ill children during many transports to a tertiary facility center.

Extensive and reliable monitoring, a sophisticated ventilator for the transport of critically ill patients, and materials for airway, ventilatory and circulatory management, and drugs should be available to the transport team. All these equipment and materials have to be mounted on a trolley, which gives access to the patient and the equipment, and is still maneuverable. 


\section{Aim and outline of the thesis}

Pediatric intensive care transport in The Netherlands is performed by either the referring specialist or a professional retrieval team from the PICU of the tertiary facility. Prior studies performed in other countries described a high incidence of complications and lack of equipment during transfers accompanied by nontrained physicians. Other studies showed a beneficial effect of professional retrieval teams. However, these studies were mainly performed in small groups of patients without a control group $[5,6,8,31]$ or with a disparate control group [7]. There is only one prospective study with a control group [32].

The question was if these data were applicable for the Dutch situation. The question to be answered was if the conclusions in other studies could also characterize the Dutch situation or might there be relevant differences with other countries. One of the reasons that there might be a difference is that since the published studies were performed there has been the introduction of the Advanced Pediatric Life Support courses and most pediatricians have a PICU training during their pediatric training. We had the opportunity to study the impact of specialist retrieval teams on pediatric interhospital transport and to compare this with a control group accompanied by non-specialized physicians, since both transport systems exist in The Netherlands, and the pediatric advanced life support is similar throughout the country.

It is of utmost importance to establish the impact of the organization and the performance of interhospital transport of critically ill children by the referring general pediatrician. This has never been the subject of a study. Being conscious of the potential transport related complications and morbidity, and the unavailability of equipment and materials for safe interhospital transport, should give rise to feelings of discomfort and insecurity to the general pediatrician, who has to accompany these transports because there is no specialist retrieval team available.

The main subject of the study in the first part of this thesis (chapter 2) was the comparison of interhospital transport of critically ill children in The Netherlands by specialist retrieval teams with inexperienced referring specialists. We hypothesized that also for the Dutch situation the transport of critically ill children by specialist retrieval teams is safer than by referring specialists, resulting in less complications during the transport, more interventions before transport, less interventions after admission on the PICU, and more equipment and materials available during transport. We expected that specialist retrieval teams would meet the criteria of intensive care during transport closer than inexperienced specialists do.

We also studied (chapter 3 ) the nature of problems encountered in organizing pediatric intensive care transport in The Netherlands, the specialist's 


\section{Chapter 1}

satisfaction or dissatisfaction with the current state of affairs in organizing such transports, and the extra workload and feelings of insecurity experienced during self-organized transports. We expected that the organization of pediatric intensive care transport would give rise to feelings of dissatisfaction in those pediatricians who have to organize the transport themselves and that these transports result in feelings of insecurity and extra workload.

In the second part of the thesis we describe the characteristics of a mobile pediatric intensive care transport unit based on a standard ambulance trolley and the construction of this unit (chapter 4). This transport unit was developed by the PICU of the university hospital Maastricht, since our specialist pediatric retrieval team needed the availability of all equipment and materials during transfer to meet the level of care that is given on the PICU itself.

On the PICU diagnoses are frequently made and therapeutic interventions frequently performed based on laboratory results. Having laboratory results at our disposal during interhospital transport brings the care during these transports even closer to that on the PICU. In chapter 5 we studied the influence of a point-of-care blood analyzer on the changes in diagnosis and therapeutic interventions, in which timing was considered to be critical to clinical outcome, during the interhospital transport of critically ill children. Point-of care blood testing has been defined as any laboratory test performed outside a central laboratory of the hospital. We hypothesized that point-of-care blood testing during transfer of critically ill children would expedite diagnosis and the initiation of treatment. 


\section{References}

1. Pearson G, Shann F, Barry P, Vyas J, Thomas D, Powell C, Field D (1997) Should paediatric intensive care be centralised? Trent versus Victoria. Lancet 349:1213-121

2. Pollack MM, Alexander SR, Clarke N, Ruttimann Ue, Tesselaar hM, BACHULIS AC (1991) Improved outcomes from tertiary center pediatric intensive care: a statewide comparison of tertiary and nontertiary care facilities. Crit Care Med 19:150-159

3. GEMKE RJ, BONSEL GJ (1995) Comparative assessment of pediatric intensive care: a national multicenter study. Pediatric Intensive Care Assessment of Outcome (PICASSO) Study Group. Crit Care Med 23:238245

4. GeMKE RJ (1997) Centralisation of paediatric intensive care to improve outcome. Lancet 349:1187-1188

5. BARRY PW, RALSTON C (1994) Adverse events occurring during interhospital transfer of the critically ill. Arch Dis Child 71:8-11

6. BRitto J, NAdel S, Maconochie I, LeVIN M, HaBIBI P (1995) Morbidity and severity of illness during interhospital transfer: impact of a specialised paediatric retrieval team. Bmj 311:836-839

7. Bellingan G, Olivier T, Batson S, WebB A (2000) Comparison of a specialist retrieval team with current United Kingdom practice for the transport of critically ill patients. Intensive Care Med 26:740-744

8. Booy R, Habibi P, Nadel S, De Munter C, Britto J, Morrison A, LeVin M (2001) Reduction in case fatality rate from meningococcal disease associated with improved healthcare delivery. Arch Dis Child 85:386-390

9. RIDLEY SA WI, ROGERS PN (1990) Secondary transport of critically ill patients. Hospital Update:289-300

10. RIDLEY S, CARTER R (1989) The effects of secondary transport on critically ill patients. Anaesthesia 44:822-827

11. Runcie CJ, ReEVE WR, WALLACE PG (1992) Preparation of the critically ill for interhospital transfer. Anaesthesia 47:327-331

12. American College OF EMERgency Physicians (2001) Managed health care organizations and emergency care. Ann Emerg Med 38:487-488

13. Dockery WK, Futterman C, Keller SR, Sheridan MJ, AKL BF (1999) A comparison of manual and mechanical ventilation during pediatric transport. Crit Care Med 27:802-806

14. Pollack MM, Ruttimann UE, Getson PR (1988) Pediatric risk of mortality (PRISM) score. Crit Care Med 16:1110-1116

15. Council of the Society of Critical Care Medicine (2000) Consensus report for regionalization of services for critically ill or injured children. Crit Care Med 28:236-239

16. Pediatric Section task Force on Admission and Discharge Criteria, SOCIETY OF CRITICAL CARE MEDICINE IN CONJUNCTION WITH THE AMERICAN College of Critical Care Medicine and the Committee on Hospital Care of the American Academy of Pediatrics (1999) Guidelines for developing admission and discharge policies for the pediatric intensive care unit. Crit Care Med 27:843-845 
17. Society of CRitical CARE Medicine (1993) Guidelines for the transfer of critically ill patients. Crit Care Med 21:931-937

18. RATCLIFFE J (1998) Provision of intensive care for children. A geographically integrated service may now be achieved. Bmj 316:15471548

19. Hanson CW, 3Rd, Deutschman CS, ANDERson HL, 3Rd, Reilly PM, BEHRINGER EC, SCHWAB CW, PRICE J (1999) Effects of an organized critical care service on outcomes and resource utilization: a cohort study. Crit Care Med 27:270-274

20. LI TC, Phillips MC, Shaw L, Cook EF, Natanson C, Goldman L (1984) On-site physician staffing in a community hospital intensive care unit. Impact on test and procedure use and on patient outcome. Jama 252:2023-2027

21. BROWN JJ, SULLIVAN G (1989) Effect on ICU mortality of a full-time critical care specialist. Chest 96:127-129

22. Pronovost PJ, Jenckes MW, Dorman T, Garrett E, Breslow MJ, ROSENFELD BA, LIPSETT PA, BASS E (1999) Organizational characteristics of intensive care units related to outcomes of abdominal aortic surgery. Jama 281:1310-1317

23. Pollack MM, Katz RW, Ruttimann UE, Getson PR (1988) Improving the outcome and efficiency of intensive care: the impact of an intensivist. Crit Care Med 16:11-17

24. GoH AY, LUM LC, ABDEL-LATIF ME (2001) Impact of 24 hour critical care physician staffing on case-mix adjusted mortality in paediatric intensive care. Lancet 357:445-446

25. GoldHILL DR, Withington PS (1998) Tertiary centers are unproved. Bmj $317: 1320$

26. OUDEN DEN AL (2001) Pediatric Intensive Care in The Netherlands, inquiry report of the Inspector of Health Care. In: www.igz.nl

27. Nipshagen MD, Polderman KH, DeVictor D, Gemke RJ (2002) Pediatric intensive care: result of a European survey. Intensive Care Med 28:17971803

28. LOPEZ-HERCE J, SANCHO L, MARTINON JM (2000) Study of paediatric intensive care units in Spain. Spanish Society of Paediatric Intensive Care. Intensive Care Med 26:62-68

29. Lopez-Herce J, RodrigueZ-Nunez A (2003) Comments on "Pediatric intensive care: result of a European survey". Intensive Care Med 29:1197

30. (2002) Policy pediatric intensive care units. Beleidsvisie pediatrische intensive care units

31. Gebremichael M, Borg U, habashi nM, Cottingham C, Cunsolo L, MCCUNN M, REYNOLDS HN (2000) Interhospital transport of the extremely ill patient: the mobile intensive care unit. Crit Care Med 28:79-85

32. Edge WE, Kanter RK, Weigle CG, WALSH RF (1994) Reduction of morbidity in interhospital transport by specialized pediatric staff. Crit Care Med 22:1186-1191

33. MACNAB AJ (1991) Optimal escort for interhospital transport of pediatric emergencies. J Trauma 31:205-209 
34. RASHID A, BHUTA T, BERRY A (1999) A regionalised transport service, the way ahead? Arch Dis Child 80:488-492

35. BLEEKER JK, RUTTEN FL, VAN LEEUWEN FL, JANSEN YG (1993) The quality of ambulance transportation between regional hospitals and a central hospital. Ned Tijdschr Geneeskd 137:1091-1095

36. BRAmAn SS, DUNn SM, AmiCo CA, MILLMAN RP (1987) Complications of intrahospital transport in critically ill patients. Ann Intern Med 107:469-473

37. Szem JW, Hydo LJ, FISCher E, KapuR S, KLEMPERER J, BARIE PS (1995) High-risk intrahospital transport of critically ill patients: safety and outcome of the necessary "road trip". Crit Care Med 23:1660-1666

38. MarX G, VANGerow B, Hecker H, LeuWer M, Jankowski M, Piepenbrock S, RUECKOLDT H (1998) Predictors of respiratory function deterioration after transfer of critically ill patients. Intensive Care Med 24:1157-1162

39. Wallen E, Venkataraman ST, Grosso MJ, Kiene K, OrR RA (1995) Intrahospital transport of critically ill pediatric patients. Crit Care Med 23:1588-1595

40. Orr RA, Venkataraman St, Cinoman Mi, Hogue BL, Singleton CA, MCCLOSKEY KA (1994) Pretransport Pediatric Risk of Mortality (PRISM) score underestimates the requirement for intensive care or major interventions during interhospital transport. Crit Care Med 22:101-107

41. BRItTo J, NADEl S, HaBIBI P, LEVIN M (1994) Pediatric risk of mortality underestimates the requirement for intensive care during interhospital transport. Crit Care Med 22:2029-2030

42. CRAY SH, HEARD CM (1995) Transport for paediatric intensive care. Measuring the performance of a specialist transport service. Paediatr Anaesth 5:287-292

43. Knowles PR, BRyden DC, KISHEN R, Gwinnutt CL (1999) Meeting the standards for interhospital transfer of adults with severe head injury in the United Kingdom. Anaesthesia 54:280-285

44. HURST JM, DAVIS K, JR., BRANSON RD, JOHANNIGMAN JA (1989) Comparison of blood gases during transport using two methods of ventilatory support. J Trauma 29:1637-1640

45. JOHANNIGMAN JA, BRANSON RD, CAMPBELL R, HURST JM (1990) Laboratory and clinical evaluation of the MAX transport ventilator. Respir Care 35:952-959

46. Campbell RS, Johannigman Ja, Branson RD, Austin PN, Matacia G, BANKS GR (2002) Battery duration of portable ventilators: effects of control variable, positive end-expiratory pressure, and inspired oxygen concentration. Respir Care 47:1173-1183

47. GARDELÖF B (2001) Mechanical ventilation during transport of critically ill patients. Int J Intensive Care 8:178-179

48. TOBIAS JD, LYNCH A, GARRETT J (1996) Alterations of end-tidal carbon dioxide during the intrahospital transport of children. Pediatr Emerg Care $12: 249-251$

49. VARDI A, LeVIN I, PARET G, BARZILAy Z (2000) The sixth vital sign: end-tidal $\mathrm{CO} 2$ in pediatric trauma patients during transport. Harefuah 139:85-87

50. JATLOW P (1993) Point of care laboratory testing in the emergency department. Am J Clin Pathol 100:591 
51. MURTHY JN, HICKS JM, SOLDIN SJ (1997) Evaluation of i-STAT portable clinical analyzer in a neonatal and pediatric intensive care unit. Clin Biochem 30:385-389

52. Papadea C, Foster J, Grant S, Ballard SA, Cate JCt, Southgate WM, PUROHIT DM (2002) Evaluation of the i-STAT Portable Clinical Analyzer for point-of-care blood testing in the intensive care units of a university children's hospital. Ann Clin Lab Sci 32:231-243

53. Parvin CA, Lo SF, Deuser SM, WeAVer LG, LeWIS LM, Scott MG (1996) Impact of point-of-care testing on patients' length of stay in a large emergency department. Clin Chem 42:711-717

54. Bhatia N, Silver P, QUINN C, SAgy M (1998) Evaluation of a portable blood gas analyzer for pediatric interhospital transport. J Emerg Med 16:871-874

55. Burritt MF, Santrach PJ, Hankins DG, Herr D, Newton NC (1996) Evaluation of the i-STAT portable clinical analyzer for use in a helicopter. Scand J Clin Lab Invest Suppl 224:121-128

56. BLEAK T, TRAUTMAN MS (1995) Use of composite material to reduce equipment weight during neonatal transport. Air Med J 14:26-29

57. MAdAR RJ, MilLIGAN DW (1994) Neonatal transport: safety and security. Arch Dis Child 71:F147-148

58. Macnab A, Chen Y, Gagnon F, Bora B, Laszlo C (1995) Vibration and noise in pediatric emergency transport vehicles: a potential cause of morbidity? Aviat Space Environ Med 66:212-221

59. Peters C, Bauer M, Speidel U, Jung E, Homberg F, Schofer O (1997) [Measuring vibrations of transport stress in premature and newborn infants during incubator transport]. Klin Padiatr 209:315-320

60. DAWSON AD, BABINGTON PC (1987) An intensive care trolley--an economical and versatile alternative to the mobile intensive care unit. Anaesth Intensive Care 15:229-233

61. Johnson K, Pearce F, Westenskow D, Ogden LL, Farnsworth S, Peterson S, White J, Slade T (2002) Clinical evaluation of the Life Support for Trauma and Transport (LSTAT) platform. Crit Care 6:439-446

62. PARK GR, JoHnson S, FERGUSON A, GRANT D (1982) A mobile intensive care unit based on a standard ambulance trolley bed. $\mathrm{Br} J$ Anaesth 54:1081-1085

63. EVANS JS, HOTTER A (1994) A novel equipment bridge for helicopter transport of critically ill patients. Anaesth Intensive Care 22:284-287

64. WISHAW KJ, MUNFORD BJ, ROBY HP (1990) The Careflight stretcher bridge: a compact mobile intensive care unit. Anaesth Intensive Care 18:234-238 


\section{Comparison of pediatric interhospital intensive care transport accompanied by}

a referring specialist or a specialist retrieval team

Vos GD, Nissen AC, Nieman FHM, Meurs AMB, Van Waardenburg DA, Ramsay G, Donckerwolcke RAMG Intensive Care Medicine, in press 


\section{Chapter 2}

\section{Abstract}

\section{Objective}

Interhospital transfers of critically ill pediatric patients in The Netherlands are accompanied by referring specialists or by specialist retrieval teams. We compared the interventions before and directly after transports and the complications and the equipment available during transports in the both groups.

\section{Design and setting}

Prospective observational clinical study in pediatric intensive care units of Dutch university hospitals.

\section{Patients}

249 pediatric patients requiring interhospital intensive care transport.

\section{Methods}

Data were collected on interhospital pediatric intensive care transports. We compared patient characteristics, interventions before and directly after transport, complications and equipment available during transport (137 accompanied by referring specialists, 112 by specialist retrieval teams).

\section{Results}

Interhospital transports accompanied by referring specialists had a longer average transport time (74.6 vs. 60.2 minutes), higher incidence of respiratory insufficiency $(56.9 \%$ vs. $41.1 \%)$, and lower incidence of circulatory insufficiency $(27.0 \%$ vs. $41.1 \%)$ as primary admission diagnoses. These transports had a lower percentage of ventilatory support $(47.4 \%$ vs. $72.3 \%)$, higher need for acute interventions directly upon arrival on the pediatric ICU, and higher incidence of critical and serious complications. In $75 \%$ of the transfers accompanied by retrieval teams interventions before the transport were deemed to be necessary. During the transports accompanied by referring specialists the equipment and materials available proved rather limited.

\section{Conclusions}

During pediatric intensive care transports accompanied by nontrained referring specialists there appears to be a higher incidence of complications, specialized equipment is more often not available, and more acute interventions are required upon arrival in the pediatric ICU. 


\section{Introduction}

Recent developments in providing intensive care for infants and children have led worldwide to centralization in tertiary centers. The reason for centralization is that critically ill children show a better clinical outcome when treated in tertiary pediatric intensive care units (PICUs) than when treated in nontertiary pediatric centers [1-5]. Also, interhospital transport of critically ill children by specialist pediatric retrieval teams tends to be associated with a lower incidence of major complications than transport by nontrained personnel [6-9]. Specialist retrieval teams are able to produce a higher degree of stabilization of the patient prior to and during transport $[7,8,10]$. Two of the eight tertiary PICUs in The Netherlands have well-organized and almost continuously accessible transport facilities. The other six centers only perform transports in specific cases, depending on the severity of the patient's condition and the availability of personnel in the PICU. This has resulted in a situation in which specialist retrieval teams do accompany about one-third of the pediatric intensive care transports. The referring specialists, who are not trained in pediatric intensive care and pediatric intensive care transport, accompany the other two-thirds. Assuming that both the level of pediatric advanced life support in the community hospitals in The Netherlands and the level of care in the PICUs in the tertiary centers are basically uniform, we undertook a study to access differences between both groups of accompanying specialists. We compared the incidence of interventions before and directly after the transfer and the complications and the availability of equipment and materials during transfer. 


\section{Patients and methods}

\section{Patient data}

Six out of the eight PICUs in The Netherlands actively participated in this study; one did not participate, and one provided data on only 2 of 46 transfers and was therefore excluded. These two centers are comparable to the six other centers included in this study in terms of patient population.

The study cohort consisted of patients (neonates excluded) below 16 years of age referred from a community hospital to one of the tertiary PICUs in The Netherlands over a 7-month period from 1 November 2000 to 31 May 2001. The referring hospitals were all Dutch community hospitals. The patients were referred directly from the emergency room, the pediatric ward, or the general intensive care unit of these hospitals. During the interhospital transport the patients were accompanied by either a physician (generally a pediatrician, sometimes an anesthetist) from the referring hospital (further referred to as referring specialist) or a specialist retrieval team from the PICU to which the patient was referred. The retrieval team consists of the team of the ground ambulance (a paramedic trained in intensive care and a driver), a pediatric intensivist or an anesthetist participating in the on-call of the PICU and occasionally a nurse of the PICU.

During the study period there were 381 interhospital pediatric intensive care transfers to one of the six participating centers. We received data from 268 $(75.1 \%)$ transports, of which $249(65.4 \%)$ were complete. Of these complete data $137(55 \%)$ transports were accompanied by the referring specialists and $112(45 \%)$ by a specialist retrieval teams of the PICU. The referring specialists were mainly pediatricians $(86.9 \%)$, and in the other transports anesthetists $(13.1 \%)$. The physicians in the retrieval team were mainly pediatric intensivists $(91.1 \%)$, in the other transports by the retrieval teams it was an anesthetist participating in the on-call for the PICU. The numbers of transfers according to the tertiary centers are presented in Table 1 (page 42). There were no statistical differences in the patients characteristics between the two groups (Table 2).

On admission to the PICU the attending intensive care specialist collected the clinical characteristics including age, Pediatric Risk of Mortality (PRISM) score, Pediatric Index of Mortality (PIM) score, acute physiology parameters, and primary admission diagnosis. There were insufficient data to allow calculation of predicted mortality before the transfer. The same specialist and the accompanying specialist collected the data of the transport, including interventions before and directly after the transfer, and the complications and the availability of equipment during the transport. 


\section{Table 2}

\begin{tabular}{|c|c|c|c|c|c|}
\hline \multicolumn{6}{|c|}{ Patient demographics on admission in the pediatric intensive care unit } \\
\hline & \multicolumn{2}{|c|}{$\begin{array}{l}\text { Referring specialist } \\
\quad(n=137)\end{array}$} & \multicolumn{2}{|c|}{$\begin{array}{l}\text { Retrieval team } \\
(n=112)\end{array}$} & \multirow[b]{2}{*}{$p$ value } \\
\hline & Mean & $\pm \mathrm{SD}$ & Mean & $\pm \mathrm{SD}$ & \\
\hline Age in years & 3.8 & 5.1 & 2.9 & 4.2 & 0.139 \\
\hline \multicolumn{6}{|l|}{ Acute physiology } \\
\hline $\mathrm{pH}$ & 7.34 & .14 & 7.36 & .12 & 0.906 \\
\hline $\mathrm{FiO}_{2}$ & 0.55 & 0.28 & 0.62 & 0.28 & 0.095 \\
\hline $\mathrm{PaO}_{2}(\mathrm{mmHg})$ & 127 & 80 & 151 & 100 & 0.198 \\
\hline $\mathrm{PaO}_{2} / \mathrm{FiO}_{2}$ & 272 & 172 & 274 & 170 & 0.801 \\
\hline $\mathrm{PaCO}_{2}(\mathrm{mmHg})$ & 43 & 19 & 43 & 27 & 0.149 \\
\hline Base excess $(\mathrm{mmol} / \mathrm{l})$ & -2.2 & 8.2 & -2.8 & 6.7 & 0.246 \\
\hline Blood pressure systolic $(\mathrm{mmHg})$ & 96 & 26 & 91 & 23 & 0.118 \\
\hline Glasgow Coma Scale score & 9.5 & 4.0 & 8.3 & 4.0 & 0.181 \\
\hline
\end{tabular}

Definitions of complications during the transport were as follows. Critical complications are endotracheal tube obstruction or dislocation, cyanosis (central cyanosis observed by the physician), bradycardia (heart rate below 60 beats per minute or reduction of the heart rate more than $30 \%$ of the baseline), circulatory arrest (asystole, ventricular fibrillation, or loss of palpable central pulses), and hypotension (reduction in blood pressure by more than $10 \%$ of the baseline and under 10 th percentile). Serious complications are neurological detoriation (reduction in Glasgow Coma Score by 2 or more points), desaturation (reduction in pulse oximetry by more than $5 \%$ for longer than $15 \mathrm{~s}$ ), hypothermia (reduction in temperature by more than $2^{\circ} \mathrm{C}$ and under $36.0^{\circ} \mathrm{C}$ ), hyperthermia (elevation in temperature by more than $2^{\circ} \mathrm{C}$ and over $39.0^{\circ} \mathrm{C}$ ), loss of venous access, tachycardia (elevation in heart rate by more than $30 \%$ of the baseline) and hypertension (elevation in blood pressure by more than $10 \%$ of the baseline and over 90th percentile).

The duration of the transport is the time from departure in the referring hospital until the arrival on the PICU. All the data were rechecked by a telephone call with the referring specialist, the transporting specialist and the attending intensivist by one of the authors and stored in a database.

\section{Statistical analysis}

Statistical analysis was performed using SPSS PC 11.0 for Windows (SPSS, Chicago, III., USA). Where appropriate $\mathrm{P}^{2}$ test, independent-groups Student's $t$ test or nonparametric tests were used to compare the characteristics, complications, and interventions of the two groups of transport, i.e., by referring 


\section{Chapter 2}

specialist or by specialist retrieval team. Results for metric data are presented as means \pm standard deviation. For PRISM and PIM scores a logarithmic transformation was used before the independent Student's $t$ test. These results are presented as median with their ranges. A $p$ value of less than 0.05 was considered to be statistically significant.

\section{Results}

Table 1 presents the predicted mortality rates (PRISM and PIM) upon admission on the PICU. There was no significant difference for PRISM $(p=0.952)$ or PIM $(p=0.070)$ between the transports by the referring specialists and the retrieval teams.

\section{Table 1}

Number of transfers and Pediatric Risk of Mortality (PRISM) according to the tertiary centers

\begin{tabular}{|c|c|c|c|c|c|c|}
\hline \multirow{3}{*}{$\begin{array}{l}\text { Tertiary } \\
\text { center }\end{array}$} & \multicolumn{3}{|c|}{ Referring specialist } & \multicolumn{3}{|c|}{ Retrieval team } \\
\hline & \multirow{2}{*}{$\begin{array}{l}\text { Number } \\
\text { of transfers }\end{array}$} & \multicolumn{2}{|c|}{ PRISM } & \multirow{2}{*}{$\begin{array}{l}\text { Number } \\
\text { of transfers }\end{array}$} & \multicolumn{2}{|c|}{ PRISM } \\
\hline & & Median & Range & & Median & Range \\
\hline 1 & 3 & 0.83 & $0.4 / 3.3$ & 25 & 1.68 & $0.3 / 93.4$ \\
\hline 2 & 39 & 1.87 & $0.3 / 86.3$ & 12 & 2.35 & $0.5 / 73.3$ \\
\hline 3 & 15 & 2.01 & $0.6 / 28.6$ & 32 & 2.41 & $0.5 / 28.3$ \\
\hline 4 & 1 & 97.2 & & 26 & 1.33 & $0.6 / 83.1$ \\
\hline 5 & 44 & 1.77 & $0.3 / 21.8$ & 12 & 2.79 & $0.3 / 39.3$ \\
\hline 6 & 35 & 3.42 & $0.4 / 98.4$ & 5 & 1.48 & $0.8 / 1.9$ \\
\hline Total & 137 & 2.01 & $0.3 / 98.4$ & 112 & 1.86 & $0.3 / 93.4$ \\
\hline
\end{tabular}

Number of transfers and Pediatric Index of Mortality (PIM) according to the tertiary centers

\begin{tabular}{|c|c|c|c|c|c|c|}
\hline \multirow{3}{*}{$\begin{array}{l}\text { Tertiary } \\
\text { center }\end{array}$} & \multicolumn{3}{|c|}{ Referring specialist } & \multicolumn{3}{|c|}{ Retrieval team } \\
\hline & \multirow{2}{*}{$\begin{array}{l}\text { Number } \\
\text { of transfers }\end{array}$} & \multicolumn{2}{|c|}{ PIM } & \multirow{2}{*}{$\begin{array}{l}\text { Number } \\
\text { of transfers }\end{array}$} & \multicolumn{2}{|c|}{ PIM } \\
\hline & & Median & Range & & Median & Range \\
\hline 1 & 3 & 0.53 & $0.3 / 2.0$ & 25 & 1.97 & $0.2 / 83.8$ \\
\hline 2 & 39 & 1.87 & $0.2 / 12.8$ & 12 & 1.43 & $0.3 / 47.5$ \\
\hline 3 & 15 & 1.80 & $0.2 / 7.1$ & 32 & 1.77 & $0.2 / 17.8$ \\
\hline 4 & 1 & 91.6 & & 26 & 2.38 & $0.3 / 44.9$ \\
\hline 5 & 44 & 1.12 & $0.2 / 9.1$ & 12 & 3.00 & $0.3 / 14.4$ \\
\hline 6 & 35 & 1.97 & $0.4 / 83.1$ & 5 & 1.16 & $0.2 / 3.3$ \\
\hline Total & 137 & 1.75 & 0.2 / 91.6 & 112 & 1.97 & $0.2 / 83.8$ \\
\hline
\end{tabular}


The duration of the transport proved to be significantly longer in the group accompanied by the referring specialist than those accompanied by a specialist retrieval team (73.8 $\square 35.4$ vs. $61.7 \square 32.4 \mathrm{~min}, p=0.022$ ). Table 3 shows frequencies and percentages of primary admission diagnosis $\left(P^{2}=8.56\right.$ by $3 \mathrm{df}$, $p=0.036)$.

\section{Table 3}

\begin{tabular}{|c|c|c|c|c|}
\hline \multicolumn{5}{|c|}{ Primary admission diagnoses } \\
\hline & \multicolumn{2}{|c|}{$\begin{array}{c}\text { Referring specialist } \\
\quad(\mathrm{n}=137)\end{array}$} & \multicolumn{2}{|c|}{$\begin{array}{c}\text { Retrieval team } \\
(\mathrm{n}=112)\end{array}$} \\
\hline & $\mathrm{n}$ & $\%$ & $\mathrm{n}$ & $\%$ \\
\hline Respiratory insufficiency & 78 & 56.9 & 46 & 41.1 \\
\hline Circulatory insufficiency & 37 & 27.0 & 46 & 41.1 \\
\hline Postoperative & 2 & 1.5 & 1 & 0.9 \\
\hline Trauma & 1 & 0.7 & 3 & 2.7 \\
\hline Neurological disturbance & 16 & 11.7 & 11 & 9.8 \\
\hline Metabolic disturbance & 1 & 0.7 & 2 & 1.8 \\
\hline Other & 2 & 1.5 & 3 & 2.7 \\
\hline Total & 137 & 100.0 & 112 & 100.0 \\
\hline
\end{tabular}

In the group with respiratory illness respiratory syncytial virus was seen in $35.5 \%$, upper airway obstruction in $16.1 \%$, pneumonia in $14.5 \%$, status astmaticus in $8.1 \%$, and central apnea in $8.1 \%$. Circulatory illness was by far most due to sepsis $(75.9 \%)$, mainly meningococcal septic shock $(68.3 \%$ of the sepsis group). Congenital heart disease was reported in the circulatory illness group in $12 \%$. In the group with neurological disturbances these were mainly related to meningitis $(29.6 \%)$, status epilepticus $(22.2 \%)$, and intracranial hemorrhage $(14.8 \%)$. A higher percentage of respiratory illness $(56.9 \%$ vs. $41.1 \%$ ) is observed in the group accompanied by the referring specialist and a higher percentage of circulatory illness $(27.0 \%$ vs. $41.1 \%)$ in the group accompanied by a specialist retrieval team. The group of patients accompanied by the referring specialist showed a significantly lower incidence of mechanical ventilation before and during the transport $(47.2 \%$ vs. $72.3 \%, p=0.001)$.

There was a high incidence of interventions before the transport in the group of patients accompanied by a specialist retrieval team. In $25.0 \%$ of these transports there was no intervention performed by the retrieval teams, in $23.2 \%$ there was one intervention, in $8.9 \%$ there were two interventions and in $42.9 \%$ there were three or more interventions deemed necessary. The most commonly performed interventions were on the respiratory area change in ventilatory settings $(36.6 \%)$ or start of mechanical ventilation $(16.1 \%)$, endotracheal intubation (16.1\%) and repositioning of endotracheal tubes (12.5\%). On the circulation area these interventions were mainly fluid resuscitation (36.6\%), start or change of vasoactive drugs $(24.1 \%)$, and the introduction of central venous 


\section{Chapter 2}

lines $(17.0 \%)$. In $2.7 \%$ of the transports by retrieval teams cardiopulmonary resuscitation was started immediately upon arrival of the team in the referring hospital.

The difference in the incidence of interventions directly upon admission to the PICU between the transfers accompanied by the referring specialist and those accompanied by specialist retrieval teams is summarized in Table 4.

\begin{tabular}{|c|c|c|c|c|c|}
\hline \multicolumn{6}{|c|}{ Frequencies of interventions directly after admission in the PICU } \\
\hline & \multicolumn{2}{|c|}{$\begin{array}{l}\text { Referring specialist } \\
\quad(n=137)\end{array}$} & \multicolumn{2}{|c|}{$\begin{array}{l}\text { Retrieval team } \\
\quad(n=112)\end{array}$} & \multirow[b]{2}{*}{$p\left(\mathrm{P}^{2}\right)$} \\
\hline & $\mathrm{n}$ & $\%$ & $\mathrm{n}$ & $\%$ & \\
\hline \multicolumn{6}{|l|}{ Major } \\
\hline Changing ventilator settings & 33 & 23.7 & 15 & 10.8 & 0.033 \\
\hline Central venous line & 30 & 21.6 & 11 & 7.9 & 0.011 \\
\hline Fluid resuscitation & 29 & 20.9 & 13 & 9.4 & 0.045 \\
\hline Additional oxygen & 27 & 19.4 & 5 & 3.6 & 0.001 \\
\hline Start or change cardiotonics & 21 & 15.1 & 13 & 9.4 & 0.395 \\
\hline Endotracheal intubation & 20 & 14.4 & 4 & 2.9 & 0.003 \\
\hline Start mechanical ventilation & 16 & 11.5 & 2 & 1.4 & 0.003 \\
\hline Repositioning endotracheal tube & 12 & 8.6 & 2 & 1.4 & 0.017 \\
\hline $\begin{array}{l}\text { Start cardiopulmonary } \\
\text { resuscitation }\end{array}$ & 2 & 1.4 & 0 & 0.0 & 0.199 \\
\hline \multicolumn{6}{|l|}{ Minor } \\
\hline Arterial line & 68 & 48.9 & 31 & 22.3 & 0.001 \\
\hline Start or change sedation & 35 & 25.2 & 9 & 6.5 & 0.001 \\
\hline Nasogastric tube & 30 & 21.6 & 5 & 3.6 & 0.001 \\
\hline Venous access & 8 & 5.8 & 0 & 0.0 & 0.009 \\
\hline
\end{tabular}

There was an overall higher incidence of interventions directly after admission on the PICU in the patients transferred by the referring specialists.

The incidence of complications during the transfers is summarized in Table 5. Severe impairment of the circulation (bradycardia and circulatory arrest) was significantly higher in the group of patients accompanied by referring specialists ( 8 vs. $0, p=0.009$ ). The incidence of hypotension was also significantly higher in the group of patients accompanied by referring specialists ( 16 vs. $7, p=0.015$ ). Of the 37 patients in the group with a primary admission diagnosis of circulatory insufficiency and accompanied by the referring specialist 12 were transferred without any monitoring of blood pressure, while all the patients with circulatory insufficiency accompanied by specialist retrieval teams were closely monitored by invasive blood pressure measurement. 


\begin{tabular}{|c|c|c|c|c|c|}
\hline \multicolumn{5}{|c|}{$\begin{array}{l}\text { Table } 5 \\
\text { Complications during pediatric interhospital intensive care transport }\end{array}$} & \\
\hline & \multicolumn{2}{|c|}{$\begin{array}{l}\text { Referring specialist } \\
\quad(\mathrm{n}=137)\end{array}$} & \multicolumn{2}{|c|}{$\begin{array}{l}\text { Retrieval team } \\
\quad(n=112)\end{array}$} & \multirow[b]{2}{*}{$p\left(\mathrm{P}^{2}\right)$} \\
\hline & $\mathrm{n}$ & $\%$ & $\mathrm{n}$ & $\%$ & \\
\hline \multicolumn{6}{|l|}{ Critical } \\
\hline Hypotension & 16 & $19.0^{\mathrm{c}}$ & 7 & 6.3 & 0.015 \\
\hline Cyanosis & 6 & 4.4 & 0 & 0.0 & 0.025 \\
\hline Bradycardia & 4 & 2.9 & 0 & 0.0 & 0.068 \\
\hline Circulatory arrest & 4 & 2.9 & 0 & 0.0 & 0.068 \\
\hline Endotracheal tube obstruction & 1 & 0.7 & 0 & 0.0 & 0.365 \\
\hline Endotracheal tube dislocation & 1 & 0.7 & 0 & 0.0 & 0.365 \\
\hline \multicolumn{6}{|l|}{ Serious } \\
\hline Desaturation & 17 & $12.6^{\mathrm{b}}$ & 2 & 1.8 & 0.002 \\
\hline Tachycardia & 10 & 7.3 & 2 & 1.7 & 0.043 \\
\hline Neurological detoriation & 9 & 6.6 & 1 & 0.9 & 0.023 \\
\hline Hyperthermia & 2 & $7.7^{\mathrm{a}}$ & 0 & 0.0 & 0.199 \\
\hline Loss of venous access & 2 & 1.5 & 1 & 0.9 & 0.683 \\
\hline Hypothermia & 1 & $3.8^{\mathrm{a}}$ & 0 & 0.0 & 0.365 \\
\hline Hypertension & 1 & $1.2^{\mathrm{c}}$ & 2 & 1.7 & 0.447 \\
\hline
\end{tabular}

Recalculation of the complications in relation to the longer transport time in the group accompanied by the referring specialist did not change the significance.

The data on the equipment and the materials not available during transport are given in Table 6. The availability of all equipment and materials (except electrocardiography and pulse oximetry) was significantly lower in the group of patients accompanied by the referring specialists. In $26(19.0 \%)$ transports accompanied by the referring specialists there was no ventilator reported to be available, and in $80(58.3 \%)$ transports a ventilator of the ambulance was available. A suitable ventilator for children with a bodyweight below $15 \mathrm{~kg}$ was available in only 17 (12.4\%) transports accompanied by the referring specialist. Specialist retrieval teams had suitable ventilators in $82(73.2 \%)$ transports. The difference in availability of ventilators was highly significant $(p<0.001)$. 


\begin{tabular}{|c|c|c|c|c|c|}
\hline \multirow{2}{*}{\multicolumn{3}{|c|}{$\begin{array}{l}\text { Table } 6 \\
\text { Equipment and materials not available during } \\
\text { care transport } \\
\qquad \begin{array}{c}\text { Referring specialist } \\
(\mathrm{n}=137)\end{array} \\
\mathrm{n} \quad \%\end{array}$}} & Ret & $\begin{array}{l}\text { team } \\
\text { 2) }\end{array}$ & \multirow[b]{2}{*}{$p\left(\mathrm{P}^{2}\right)$} \\
\hline & & & $\mathrm{n}$ & $\%$ & \\
\hline $\begin{array}{l}\text { Electrocardiography } \\
\text { Respiration } \\
\text { Oxygen saturation } \\
\text { Non-invasive blood pressure } \\
\text { Invasive blood pressure }\end{array}$ & $\begin{array}{r}0 \\
5 \\
4 \\
58 \\
128\end{array}$ & $\begin{array}{r}0.0 \\
3.6 \\
2.9 \\
42.3 \\
93.4\end{array}$ & $\begin{array}{l}0 \\
0 \\
0 \\
0 \\
0\end{array}$ & $\begin{array}{l}0.0 \\
0.0 \\
0.0 \\
0.0 \\
0.0\end{array}$ & $\begin{array}{l}0.041 \\
0.068 \\
0.001 \\
0.001\end{array}$ \\
\hline $\begin{array}{l}\text { Temperature } \\
\text { End tidal } \mathrm{CO}_{2} \\
\text { Suction } \\
\text { Resuscitation bag } \\
\text { Laryngoscope }\end{array}$ & $\begin{array}{r}113 \\
123 \\
26 \\
19 \\
41\end{array}$ & $\begin{array}{l}82.5 \\
89.8 \\
19.0 \\
13.9 \\
29.9\end{array}$ & $\begin{array}{r}25 \\
37 \\
0 \\
0 \\
0\end{array}$ & $\begin{array}{r}22.3 \\
33.0 \\
0.0 \\
0.0 \\
0.0\end{array}$ & $\begin{array}{l}0.001 \\
0.001 \\
0.001 \\
0.001 \\
0.001\end{array}$ \\
\hline $\begin{array}{l}\text { Endotracheal tube } \\
\text { Suction catheters } \\
\text { Thorax drain } \\
\text { Infusion needle } \\
\text { Intraosseous needle } \\
\text { IV fluid }\end{array}$ & $\begin{array}{l}40 \\
49 \\
90 \\
26 \\
99 \\
30\end{array}$ & $\begin{array}{l}29.2 \\
35.8 \\
65.7 \\
19.0 \\
72.3 \\
21.9\end{array}$ & $\begin{array}{r}0 \\
0 \\
9 \\
0 \\
15 \\
0\end{array}$ & $\begin{array}{r}0.0 \\
0.0 \\
8.0 \\
0.0 \\
13.4 \\
0.0\end{array}$ & $\begin{array}{l}0.001 \\
0.001 \\
0.001 \\
0.001 \\
0.001 \\
0.001\end{array}$ \\
\hline $\begin{array}{l}\text { Medication for CPR } \\
\text { Medication for intubation } \\
\text { Medication for sedation } \\
\text { Medication for circulation } \\
\text { Medication for convulsions } \\
\text { Resuscitation chart }\end{array}$ & $\begin{array}{l}63 \\
67 \\
61 \\
78 \\
74 \\
86\end{array}$ & $\begin{array}{l}46.0 \\
48.9 \\
44.5 \\
56.9 \\
54.0 \\
62.8\end{array}$ & $\begin{array}{r}0 \\
0 \\
0 \\
5 \\
0 \\
21\end{array}$ & $\begin{array}{r}0.0 \\
0.0 \\
0.0 \\
4.5 \\
0.0 \\
18.8\end{array}$ & $\begin{array}{l}0.001 \\
0.001 \\
0.001 \\
0.001 \\
0.001 \\
0.001\end{array}$ \\
\hline
\end{tabular}

\section{Discussion}

The characteristics of pediatric patients referred from a community hospital to a tertiary pediatric intensive care unit accompanied by the referring specialist or by a specialist retrieval team of one of the PICUs were not significantly different, except for duration of transport and primary admission diagnosis. Although the differences in primary diagnosis could be a potential bias, it is our opinion that it is not a significant bias because the PRISM and PIM scores in the group of patients with respiratory insufficiency and circulatory insufficiency did not show a significant difference. The percentages of the transports accompanied by the referring specialist and the specialist retrieval team in this study was $55 \%$ vs. $45 \%$, which is different from the distribution of all pediatric intensive care transports in The Netherlands (2/3 vs. $1 / 3)$. This difference is mainly due to the exclusion of the two PICUs that do not have a retrieval team to their disposal.

The PRISM and PIM scores tend to be low with a median of 1.9 and 1.8 both showing a wide range. Because in a high number of transports data were 
missing, full calculation was impossible in these transports, and therefore PRISM and PIM scores are probably underscored. A recent publication of the comparison of three scoring systems for mortality risk among retrieved pediatric intensive care patients also shows the difficulty in collecting data on mortality risk. In this publication PIM score resulted in more complete data collection (88\%) than pre-ICU PRISM (24\%) and PRISM (60\%) [11].

Stabilization of the patient prior to the transport by retrieval teams and the greater number of interventions by these teams compared to the transports by the referring specialists could have led to a lower predicted mortality upon admission on the PICU and probably the predicted mortality scores were higher before the transfer in this group as is shown by the group of the PICU in the St. Mary's Hospital in London [7,9]. In particular, interventions to secure the airway and to start mechanical ventilation were performed frequently by these teams [7]. Our finding that there was a higher percentage of mechanical ventilation of patients accompanied by a specialist retrieval team tends to support this. The high incidence of endotracheal intubations directly upon admission on the PICU and the high incidence of respiratory related complications during the transport in the group of patients accompanied by the referring specialists suggests that these interventions should have been done prior to transport. In our personal communications with these specialists by far the most common reason to decide not to intubate the patient prior to the transport was the lack of skills to handle intubation and mechanical ventilation related complications and the lack of specialized equipment and materials during transport. Since in all referring hospitals anesthetists are permanently available, there is no lack of support of the endotracheal intubation during the initial treatment.

Our findings of a high incidence of interventions by a specialist retrieval team before the transport is in agreement with the literature [7]. The high incidence of interventions directly after admission on the PICU in the group of patients accompanied by the referring specialist has been previously reported [7]. The expert opinion of PICU specialists was that in a high percentage of the transports accompanied by the referring specialists interventions should have been performed before the transfer.

The high incidence of complications during transport in the group of patients accompanied by referring specialists is comparable to reports in the literature [6]. However, as a percentage of the number of transfers it is lower in our study. This might be due to our criteria for defining complications or by an underestimation by the referring specialists. The incidence of hypotension in the group of patients accompanied by the referring specialists may be underestimated due to the absence of continuous blood pressure monitoring in the majority of these transfers. Another explanation for the fewer complications in this study than in other studies is that the referral specialists in this study 


\section{Chapter 2}

were better trained than in the other studies. However, the difference in complications between the referral specialists and the retrieval teams is still high.

The materials and medication necessary for intensive care transport were often reported to be lacking in transports accompanied by referring specialists.

During the transports of infants and small children (weighing less than $15 \mathrm{~kg}$ ) accompanied by the referring specialists artificial ventilation was carried out mostly by hand-bagging, because in $88.5 \%$ of these transfers there was no ventilator available suitable for these patients. In older children accompanied by these specialists artificial ventilation was also by hand-bagging in most transports. Manual ventilation during transport results in greater fluctuation of ventilatory parameters, such as tidal volumes and peak inspiratory pressures, from an established baseline than occurs with the use of a transport ventilator [12]. Given this, and since in most cases no PEEP valve was used, most patients accompanied by referring specialists were not ventilated with sufficient PEEP and controlled tidal volumes and were exposed to a high potential risk of ventilator induced lung injury.

The high incidence of complications reported in the group of patients accompanied by the referring specialists may be related not only to the lack of experience and know-how of the accompanying specialists but also to the lack of pretransport interventions and to the absence or insufficiency of specialized equipment, materials, and medication available during transport. On the other hand, specialist retrieval teams bring their expertise and equipment to the patient in the referring hospital, and thereby the intensive care of the patient begins even before the transfer.

In our opinion, the necessity for specialist retrieval teams to accompany interhospital pediatric intensive care transport is evident from the insufficient level of care during transports accompanied by nontrained referring specialists, which leads to a higher incidence of complications during transport. Professional, fully equipped retrieval teams should be organized on a permanent, 24-h per day basis, staffed by specialists trained in pediatric intensive care and pediatric intensive care transport. Only then can the level of care during transport approach the level of care on the pediatric intensive care unit itself. 


\section{Acknowledgements}

We thank the physicians of the pediatric intensive care units participating in the data sampling. The participating PICUs were those of the University Hospitals of Groningen (Dr. MJIJ Albers), Amsterdam (Dr. AP Bos), Nijmegen (Dr. LGFM van 't Hek), Rotterdam (Dr. E van der Voort) and Utrecht (Prof. AJ van Vught). We also thank Anja Lemmerlijn and Lilian Vorstenbosch for their assistance in time-consuming phone calls and the import of data into the database.

\section{References}

1. Pearson G, Shann F, Barry P, Vyas J, thomas D, Powell C, Field D (1997) Should paediatric intensive care be centralised? Trent versus Victoria. Lancet 349:1213-1217

2. Pollack mM, Alexander SR, Clarke n, Ruttimann Ue, Tesselaar hM, BACHULIS AC (1991) Improved outcomes from tertiary center pediatric intensive care: a statewide comparison of tertiary and nontertiary care facilities. Crit Care Med 19:150-159

3. Gemke RJ, Bonsel GJ (1995) Comparative assessment of pediatric intensive care: a national multicenter study. Pediatric Intensive Care Assessment of Outcome (PICASSO) Study Group. Crit Care Med 23:238245

4. GemKe RJ (1997) Centralisation of paediatric intensive care to improve outcome. Lancet 349:1187-1188

5. Goh AY, Abdel-Latif Mel A, LUm LC, Abu-BaKAR MN (2003) Outcome of children with different accessibility to tertiary pediatric intensive care in a developing country - a prospective cohort study. Intensive Care Med 29:97-102

6. BARRY PW, RALSTON C (1994) Adverse events occurring during interhospital transfer of the critically ill. Arch Dis Child 71:8-11

7. Britto J, Nadel S, Maconochie I, LeVIn M, HabiBI P (1995) Morbidity and severity of illness during interhospital transfer: impact of a specialised paediatric retrieval team. BMJ 311:836-839

8. Bellingan G, Olivier T, Batson S, Webb A (2000) Comparison of a specialist retrieval team with current United Kingdom practice for the transport of critically ill patients. Intensive Care Med 26:740-744

9. Booy R, Habibi P, Nadel S, de Munter C, Britto J, Morrison A, LeVIn M (2001) Reduction in case fatality rate from meningococcal disease associated with improved healthcare delivery. Arch Dis Child 85:386-390

10. BRItTo J, NADEL S, LeVIN M, HabIBI P (1995) Mobile paediatric intensive care: The ethos of transfering critically ill children. Care of the Critically III 11: 235-238 


\section{Chapter 2}

11. Tibby SM, taylor D, Festa M, Hanna S, Hatherill M, Jones G, Habibi P, DURWARD A, MURDOCH IA (2002) A comparison of three scoring systems for mortality risk among retrieved intensive care patients. Arch Dis Child 87:421-425

12. Dockery WK, Futterman C, Keller SR, Sheridan MJ, AKL BF (1999) A comparison of manual and mechanical ventilation during pediatric transport. Crit Care Med 27:802-806 


\section{Problems in interhospital pediatric intensive care}

transport in The Netherlands:

\section{Results from a survey of}

\section{general pediatricians}

Vos GD, Nieman FHM, Meurs AMB, Van Waardenburg DA,

Ramsay G, Donckerwolcke RAMG

Intensive Care Medicine 2003; 29: 1555-1559 


\section{Chapter 3}

\section{Abstract}

\section{Objective}

Interhospital pediatric intensive care transport accompanied by non-trained specialists usually occurs with inadequate equipment and has been associated with a high incidence of complications. These facts have serious consequences for patients but also can be very disconcerting for the specialist. This survey was undertaken to gain insight into the problems encountered in organizing pediatric intensive care transport in The Netherlands, to measure the specialist's satisfaction or dissatisfaction with the current state of affairs in the organization of such transports, and additional workload and feelings of insecurity experienced during self-organized transports.

\section{Design}

Survey, retrospective.

\section{Setting}

A postal questionnaire sent to all pediatricians of community hospitals in The Netherlands.

\section{Methods}

Results of direct questioning are given as discrete frequencies. After factor and reliability analysis 5-point Likert scale items are summed up in scale constructions. Relationships between scales are examined in regression analysis.

\section{Results}

Pediatricians appear to be satisfied with current specialist retrieval teams if these teams are available in their region, and highly dissatisfied if these teams are not available. Many nontrained specialists consider these transports burdening tasks with a high workload, and they feel insecure during these transports, especially if they report lack of knowledge of the transport equipment.

\section{Conclusions}

The need for pediatric specialist retrieval teams in The Netherlands is seen not only in the insufficient level of care delivered by accompanying non-trained specialists and the reported high incidence of complications as shown in the literature but also in the dissatisfaction and high stress of these specialists. 


\section{Introduction}

Recent developments in providing intensive care for children has led to centralization in tertiary centers. The reason is the evidence that critically ill children show a better clinical outcome when treated in tertiary pediatric intensive care units than when treated in nontertiary pediatric centers [1-4]. From the literature it is known that interhospital transport of critically ill children by nontrained personnel tends to be associated with a higher incidence of major complications than transport by specialized pediatric retrieval teams [5-8]. Specialist retrieval teams are better able to stabilize of the patient before to and during transport $[6,7]$.

The number of admissions in the eight tertiary pediatric intensive care centers in The Netherlands (16.1 million inhabitants in 2001, from whom 3.3 million children aged 0 -16 years) averages 4500 each year, of whom about 1000 critically ill pediatric patients are referred by community hospitals. Specialist retrieval teams accompany one-third of these transports; general pediatricians from referring hospitals specialized neither in pediatric intensive care nor in pediatric intensive care transports accompany the remaining transports. Two out of the eight tertiary centers in The Netherlands currently perform pediatric intensive care transport facilities on a regular base, while the other tertiary centers perform these facilities on an incidental base.

This study focused on the problems encountered in self organizing and performing transport of critically ill children by general pediatricians in community hospitals who are not trained in pediatric intensive care and pediatric intensive care transport. In a survey we inquired about the implications that such transports have for general pediatricians. We sent a postal questionnaire to all general pediatricians in community hospitals in The Netherlands and asked for their experiences and opinions on these transports and recorded their self-reported stress and feelings of uncertainty during transports. 


\section{Chapter 3}

\section{Methods}

The questionnaire was sent by post to all 417 pediatricians working in community hospitals in The Netherlands and registered by the Dutch Association of Pediatrics. The questionnaire was returned by 256 pediatricians $(61.5 \%)$, and 236 responses $(56.6 \%)$ were considered to be sufficiently complete for further analysis. The number of respondents and their affiliation with one of the eight tertiary centers is presented in Table 1.

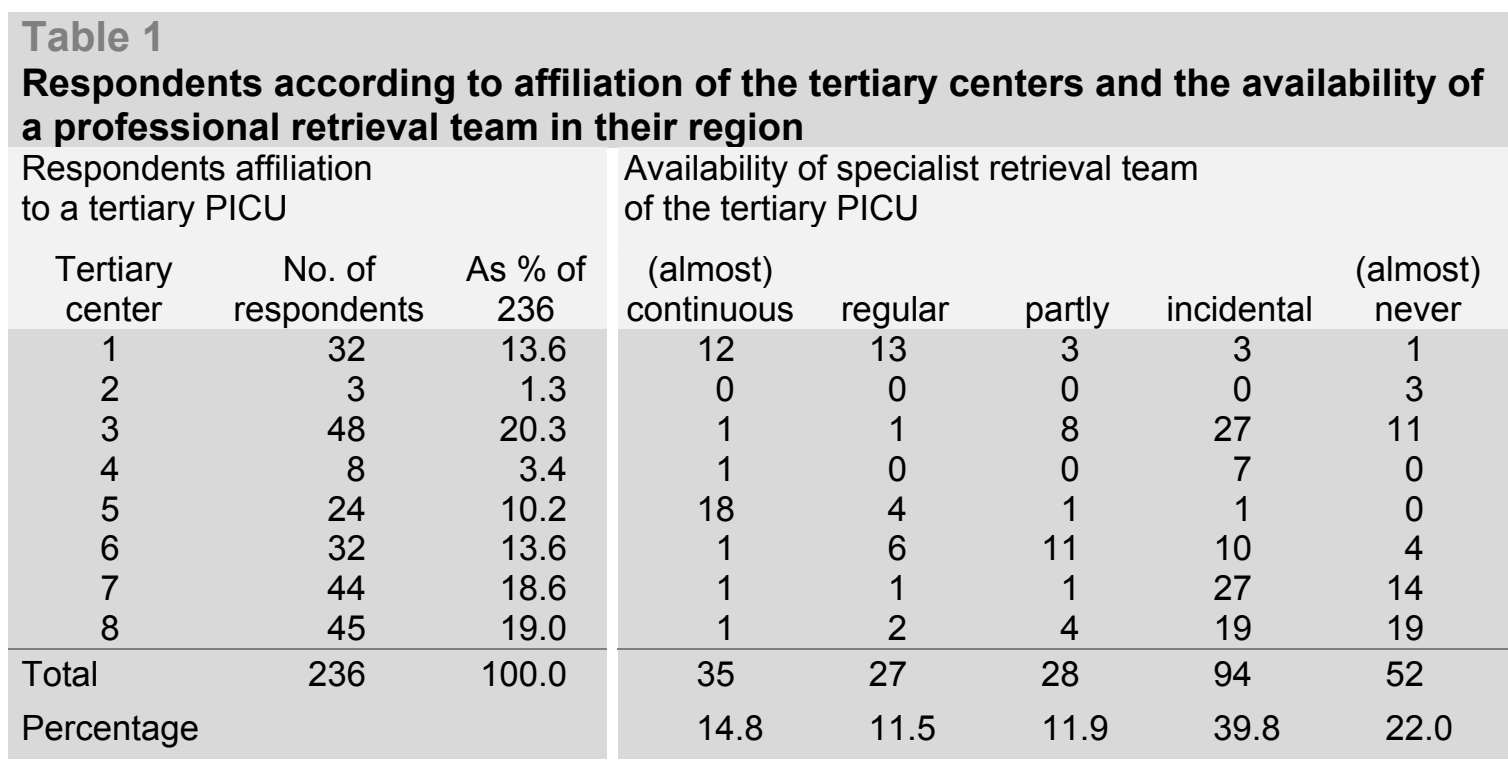

Reported availability of specialist retrieval teams of these tertiary centers is also presented in Table 1.

Questionnaire items were subdivided into three areas, concerning self-reported working conditions, opinions, and evaluations of a general pediatrician occupied with the referral of critically ill children.

1. Information on the tertiary center which is generally referred to, the presence or absence of a specialist retrieval team at this center, and primary admission diagnosis of pediatric patients referred to one of the pediatric intensive care units. Also, the self-reported professional know-how of the equipment available during the transport.

2. The extent in which pediatricians are satisfied or dissatisfied with the current status of affairs of interhospital pediatric intensive care transport in their region.

3. The additional workload caused by self-organized transports as evaluated by the pediatrician, and feelings of insecurity or emotional stress during such transports. 
Aspects in area 1 were phrased as direct questions, while questions in area 3 were presented as 5-point Likert scale items containing statements with which respondents could agree or disagree. Questions in area 2 were also presented as 5-point Likert scale items; here statements on the current status of transportation arrangements were presented as items on which respondents could show their satisfaction or dissatisfaction.

\section{Data analysis}

\section{Preliminary statistics}

Reported information of area1 is presented as frequencies and percentages.

Five-point Likert scale items from area 2 and 3 at first were examined in item analysis. Highly skewed frequencies in items were not present in the two blocks of items, and therefore none had to be removed from analysis. Next a factor analysis was carried out separately for area 2 and area 3 . Using pairwise deletion of missing data, an oblique rotation technique and maximum likelihood estimation, two of the 9 items in area 2 had to be removed from analysis because of multiple high factor loadings on both of the two dominant pattern loading matrix factors. The pattern matrix then contained two factors and communalities that turned out to be sufficiently high $(>0.50)$. The first factor from this area can be described as "satisfaction with current transport facilities of tertiary centers" (Cronbach's $\square=0.87$ ). Eventually the scale was constructed additively with equal weighting, and scale values were redefined in the original scale scores ranging from 1 (highly satisfied with current facilities) to 5 (highly dissatisfied).

In area 3 one of the eight items proved to be poorly correlated with other items. The items in area 3 measure additional workload and feelings of insecurity or stress caused by self-organized transports as evaluated by the responding specialists. Among the remaining seven items two rather politically phrased items were also removed from the factor analysis (Cronbach's $\square$ 0.41). The correlations between the remaining five items in area 3 can be described by a two-factor model: "feelings of uncertainty during self-accompanied transports" $(\square=0.76)$ and "additional burdening of these transports" $(\square=0.57)$. Both remaining scales were constructed additively with equal weighting, and scale values were again redefined in the original scale scores ranging from 1 (feeling highly insecure or intensely burdened in workload) to 5 (feeling highly sure of one's self, or not feeling burdened at all). 


\section{Chapter 3}

\section{Subsequent data analysis}

The resulting scales were used as variables in regression analysis. The main purpose of this analysis was to examine differences in (dis)satisfaction between respondents having access to specialist retrieval teams and those not having these teams at their disposal. The first hypothesis was that regarding satisfaction or dissatisfaction with the current status of the organization of pediatric interhospital transport the respondent would be guided by his/her opinion on the additional burden in workload caused by these transports and by feelings of (in)security during transports. Variables from area 1 ("working conditions") were also hypothesized to be related to the (dis)satisfaction about the availability of specialist retrieval teams.

The second hypothesis was that these same variables are related both to the reported burden of workload these transports produce and to feelings of security or insecurity in accompanying these transports. Multiple regression analysis was used to test these hypotheses. First, for each dependent variable a regression equation was calculated using forward selection of predictors assumed to be related to the dependent variable. If predictors proved to be nonsignificant in such preliminary models, they were deleted from the equation, and the regression analysis was repeated without them, until all relevant predictors in the model had statistically significant regression coefficients. Next, each predictor was entered separately into the model to test the F-ratio of the additional variance explained in the dependent variable.

SPSS-PC version 10.0 was used to analyze the data. A $p$ value equal or lower than 0.05 was considered to be statistically significant in all types of analysis.

\section{Results}

Respiratory insufficiency was the primary indication for transfer in $50.7 \%$ of the cases. Most of these patients were suffering from a Respiratory Syncytial Virus infection, while upper airway obstructions and pneumonia were also frequently given causes of respiratory insufficiency. Circulatory insufficiency was an important primary indication for transfer in $35.2 \%$. Septic shock, especially meningococcal septic shock was the most frequently mentioned diagnosis in this group. Among patients with neurological disturbances (11.5\%) the most frequently reported diagnosis was status epilepticus.

The self-reported knowledge of the equipment during interhospital pediatric intensive care transport was sufficient in $49 \%$ of the respondents who actually accompany these transports themselves. Six percent of the respondents were in doubt of their knowledge and $45 \%$ reported to have insufficient knowledge. 
Specialists in the community hospitals who had specialist retrieval teams at their disposal were highly satisfied with the current state of affairs, but they were less satisfied if they occasionally had to accompany transports themselves (Fig. 1A). Specialists who accompanied the majority or all of their transfers of critically ill pediatric patients were highly dissatisfied with this situation. Specialists in the regions of a center with a pediatric transport team available were satisfied with the current status, while specialists in a region with no such teams available on a regular basis were dissatisfied about this (Fig. 1B). For the analysis of satisfaction on the state of affairs in self organized and accompanied transport we used only the questionnaires of 164 respondents who reported to have been actually transporting children themselves during the past 5 years and had no missing data on the items of the Likert scales.

\section{Figure 1}

\section{Satisfaction or dissatisfaction with availability of specialist retrieval teams}

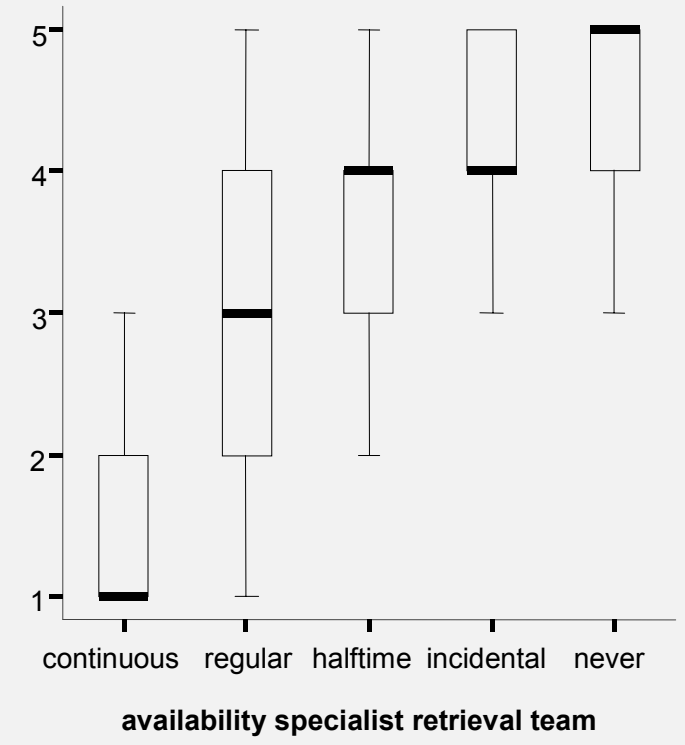

1A: Satisfaction and dissatisfaction according to the availability of specialist retrieval teams.

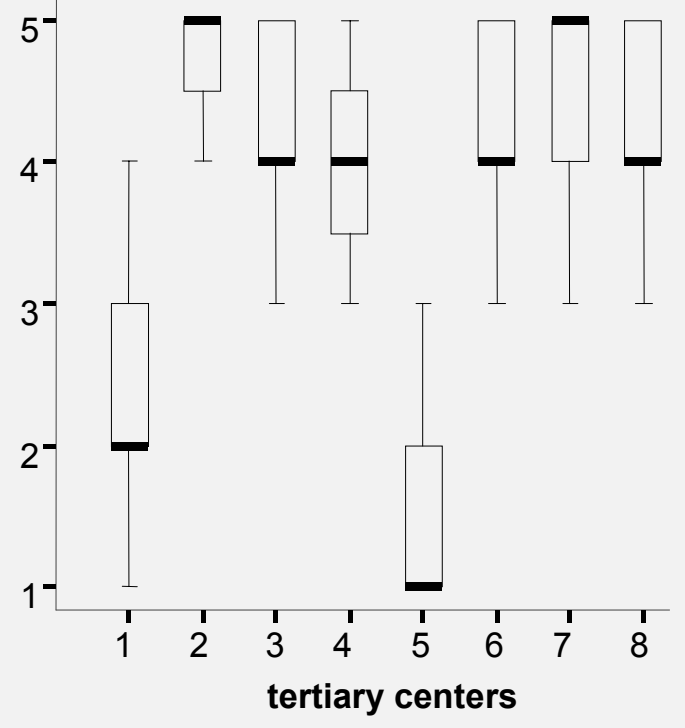

1B: Satisfaction and dissatisfaction according to the tertiary center.

Center 1 and 5 having specialist retrieval teams on a continuous or regular basis (Table 1).

On the $Y$ axis (dis)satisfaction with availability or absence of specialist retrieval teams. A low value correspondents with "highly satisfied", a high value with "highly dissatisfied". Thick lines are median values.

Table 2 presents the results of the regression analysis in which (dis)satisfaction with the current arrangement on the transport of critically ill children was entered as dependent on other variables, listed above. 


\section{Chapter 3}

Table 2A shows that two factors were significantly related to satisfaction or dissatisfaction about the current status of arrangements. First, if specialist retrieval teams were at one's disposal in the region where one is working, respondents appeared to be significantly more satisfied with this arrangement than respondents who did not have these teams at their disposal. Respondents appeared to be even more satisfied if availability of these teams was continuously assured. If these teams were not available, they were very dissatisfied with the current status of affairs. Secondly, the self-defined additional workload from accompanying transports had a lower, but statistically significant relationship with satisfaction or dissatisfaction on the current arrangements of transport facilities. If respondents described a heavy additional workload from accompanying transports of critically ill children themselves, they were more dissatisfied with the current organization than if they reported to experience less or no extra workload at all.

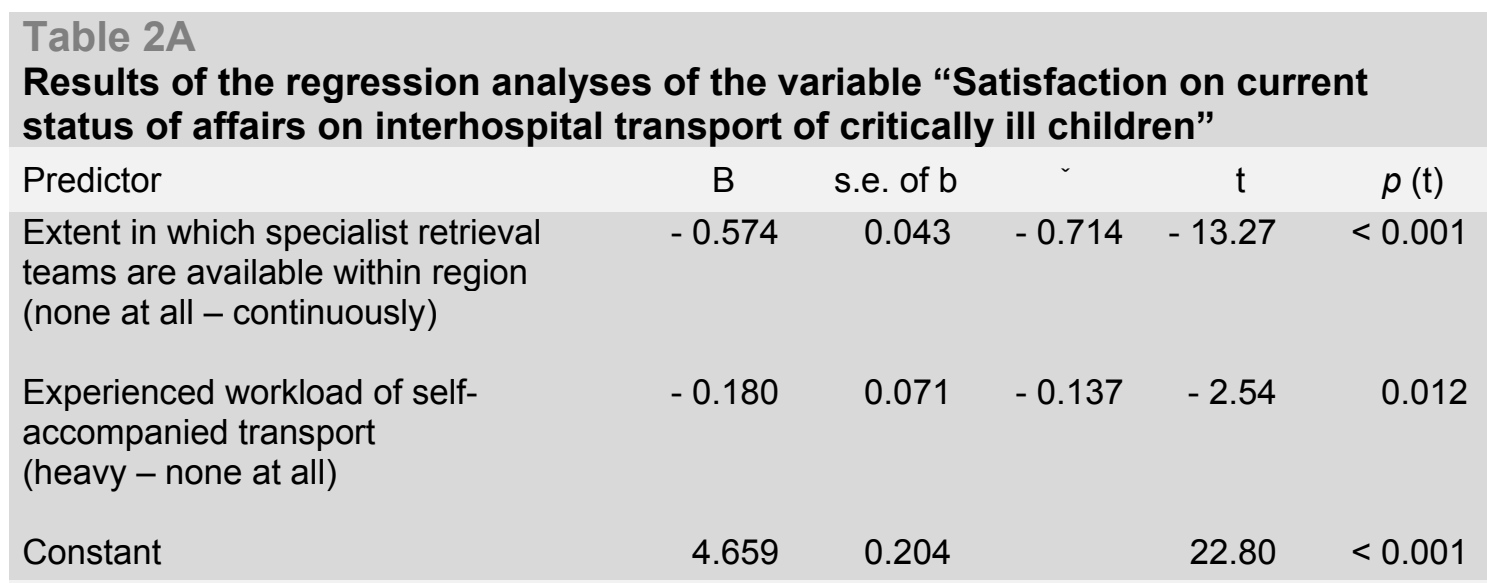

Listwise deletion of missing cases ( $n=164$; variance explained: 0.534 ).

A low value on the dependent variable corresponds with "highly satisfied", a high value with "highly dissatisfied".

Table 2B presents the results of the regression analysis in which the selfreported additional workload associated with transporting critically ill children was entered as dependent on variables in the second hypothesis. The only variable that was statistically significantly related to this extra workload was "feelings of insecurity during transport". High levels of insecurity were related to high reported additional workload, and low levels of insecurity to low additional workload. The number of children that one was transported annually had no relationship at all with reported extra workload. 


\section{Table 2B}

Results of the regression analyses of the variable "Experienced workload of self-accompanied transport"

Predictor

Feeling insecure during selfaccompanied transport

(highly - not at all)

$\begin{array}{ccccc}\text { B } & \text { s.e. of b } & - & t & p(t) \\ 0.341 & 0.064 & 0.389 & 5.37 & <0.001\end{array}$

$1.748 \quad 0.168$

$10.38<0.001$

Listwise deletion of missing cases $(\mathrm{N}=164$; variance explained: 0.151$)$.

A low value on the dependent variable corresponds with "heavy extra workload experienced", a high value with "no extra workload at all".

Table $2 \mathrm{C}$ shows the regression analysis on self-reported feelings of insecurity during transports of critically ill children (second hypothesis). First, the greater knowledge of transport equipment professed to have, the less insecurity was felt during transport. Secondly, the higher the number of children one reported transporting, the lower the feelings of insecurity were; conversely, the lower the number, the higher was the insecurity that one felt during self-organized transports.

\section{Table 2C}

Results of the regression analyses of the variable "Feelings of insecurity during self-accompanied transport"

\section{Predictor} B s.e. of $b$

Self-indicated knowledge of equipment $\quad-0.358$

$0.066-0389$

available during transport

(high - low)

$\begin{array}{llllll}\begin{array}{l}\text { Number of transports undertaken } \\ \text { during the past } 5 \text { years } \\ (1-10 \text { or more })\end{array} & 0.148 & 0.076 & 0.140 & 1.94 & 0.054 \\ \text { Constant } & 2.706 & 0.313 & & 8.66 & <0.001\end{array}$

Listwise deletion of missing cases $(N=164$; variance explained: 0.194$)$.

A low value on the dependent variable corresponds with "highly insecure", a high value with "not insecure at all". 


\section{Discussion}

Indications for transfer in this study, mainly respiratory and circulatory insufficiency, were quite similar to those reported in the literature $[5,6]$. Specialists who had specialist retrieval teams at their disposal were highly satisfied with the current status of affairs, as shown in Fig. 1. If they had to accompany transports themselves, the level of satisfaction was much lower. This might be due to the fact that in this condition they perform interhospital transport on a sporadic basis, leading to higher feelings of insecurity due to lack of experience. However, specialists who accompanied most or all of their transfers of critically ill pediatric patients were highly dissatisfied with this situation. Additional workload and, indirectly, feelings of insecurity originating from self-accompanied transports are a source for their dissatisfaction with the current status of affairs, but dissatisfaction may be related predominantly to the knowledge that current care for these patients is insufficiently organized, and that this may lead to higher risks for serious patient complications while specialist retrieval teams perform safe interhospital transfer, as shown in the literature [5-8].

The availability of specialist retrieval teams for pediatric patients differs per region. This is due mainly to historical factors. Specialists in the regions of a center with a pediatric transport team were satisfied with the current state, while those in a region with no such teams available were dissatisfied (Fig. 1B). Acceptance of this situation by the pediatricians in community hospitals in the regions where there is no specialist retrieval team present on a continuous basis is surprising. In recent years attempts to improve the interhospital pediatric intensive care transport facilities in The Netherlands have been undertaken mainly by the specialists of the tertiary pediatric intensive care centers. There has been some improvement over the last years, where most pediatric ICU centers now perform interhospital transports during daytime on working days.

A high percentage (45\%) of referring specialists reported that their knowledge of equipment available during interhospital transport was not sufficient. This lack of knowledge was an important reason for the feelings of insecurity during selfaccompanied transport. We presume that this is also a problem in other countries and might be one of the reasons for the high incidence of complications reported in the literature during interhospital transports of critically ill patients accompanied by inexperienced specialists[5,7]. Specialists in community hospitals generally have no experience in the use of sophisticated equipment, interventions, and medication. Given the complexity of modern (pediatric) intensive care it is difficult for them to cope during transports, and the number of self accompanied transports is too small to acquire know-how and 
experience in the use of transport equipment and medication. Therefore not only are the risks for the patient in transports accompanied by non-trained and under-experienced specialists higher, but also no solution can be found to alleviate the feelings of insecurity in such working conditions. The reported workload was directly related to feelings of insecurity, and not to the number of transports.

The need for fully fledged professional interhospital pediatric transport facilities in The Netherlands is evident not only from the insufficient level of care during transports accompanied by nontrained specialists, which may lead to a high incidence of serious and critical complications during these transports, but also from the dissatisfaction and high workload of the specialists of referring hospitals who accompany these transports. Professional, fully equipped retrieval teams should be organized on a continuous basis and staffed by specialists trained in pediatric intensive care and pediatric intensive care transport.

\section{References}

1. Pearson G, Shann F, Barry P, Vyas J, Thomas D, Powell C, Field D (1997) Should paediatric intensive care be centralised? Trent versus Victoria. Lancet 349:1213-1217

2. Pollack, mM, Alexander SR, Clarke n, Ruttimann Ue, Tesselaar hM, BACHULIS AC (1991) Improved outcomes from tertiary center pediatric intensive care: a statewide comparison of tertiary and nontertiary care facilities. Crit Care Med 19:150-159

3. GEMKE RJ, BONSEL GJ (1995) Comparative assessment of pediatric intensive care: a national multicenter study. Pediatric Intensive Care Assessment of Outcome (PICASSO) Study Group. Crit Care Med 23:238245

4. GEMKE RJ (1997) Centralisation of paediatric intensive care to improve outcome. Lancet 349:1187-1188

5. BARRY PW, RALSTON C (1994) Adverse events occurring during interhospital transfer of the critically ill. Arch Dis Child 71:8-11

6. BRItTo J, NADEl S, MACONOCHIE I, LeVIN M, HABIBI P (1995) Morbidity and severity of illness during interhospital transfer: impact of a specialised paediatric retrieval team. BMJ 311:836-839

7. Bellingan G, Olivier T, Batson S, Webb A (2000) Comparison of a specialist retrieval team with current United Kingdom practice for the transport of critically ill patients. Intensive Care Med 26:740-744

8. Booy R, Habibi P, NAdEl S, de Munter C, BRitto J, Morrison A, LeVIn M (2001) Reduction in case fatality rate from meningococcal disease associated with improved healthcare delivery. Arch Dis Child 85:386-390 


\title{
Interhospital pediatric intensive
}

\author{
care transport:
}

A novel transport unit based on

a standard ambulance trolley

Vos GD, Buurman WA, van Waardenburg DA, Visser TPL, Ramsay G, Donckerwolcke RAMG

European Journal of Emergency Medicine 2003; 10: 195-199 


\section{Abstract}

A recent development in providing intensive care for children is that it is more and more centralized in tertiary centers. Centralization of intensive care facilities for children in tertiary centers demands a safe and well-organized transport system. The transfer of critically ill children from a referring general hospital to a tertiary pediatric intensive care center should be performed by a specially trained and fully equipped transport team. During the transfer of these children continuous intensive care facilities should be provided. The minimal requirements of equipment and materials for transport that allow such care have been determined. The equipment consists of a monitor allowing continuous measurement of vital signs, a defibrillator, tools for airway and ventilatory management, an oxygen source, suction unit, fluid and electrolyte management, medication, resuscitation chart and a communication system. A mobile pediatric intensive care unit was constructed in order to store this equipment, including easily accessible ventilator and materials optimized for close patient observation and ventilator control.

\section{Introduction}

Since there is substantial evidence that critically ill children have a better outcome if treated in tertiary pediatric intensive care units (PICU) rather than in non-tertiary pediatric centers [1-4], and therefore the provision of intensive care for children has become centralized in tertiary centers in most countries. This results in more interhospital intensive care transports. These transports of critically ill children by non-trained persons results in a high incidence of complications [5], whereas transports by specialized pediatric retrieval teams result in minor complications and stabilization of the patient during transport [6]. Specialized pediatric retrieval teams must provide all equipment and materials necessary for advanced life support and emergency treatment for children of all ages and body weights. It is generally accepted that instability of the patient and complications during transport are minimized by optimal resuscitation and stabilization before transport [7-10], and by avoiding interruptions in ventilation and monitoring en route [7]. A major problem is the storage of the equipment and materials in such a way that these are readily accessible and optimally placed for patient monitoring. This paper describes a mobile pediatric intensive care transport unit developed to meet the needs for transportation of critically ill children.

Previously all necessary equipment and materials were mounted on the trolley of the ambulance, but this proved cumbersome. Mobile Intensive Care Units 
(MICU's) have been described for use in ambulances for the transport of adult patients [11,12], but not for pediatric patients. The mobile pediatric intensive care transport unit described, containing all equipment and materials required for transport and based on a standard ambulance trolley, was developed jointly by the pediatric intensivists and nurses of our PICU, instrumentation engineers of our hospital and personnel of the ambulances.

\section{System description}

\section{A. The general requirements for the transport unit}

The PICU in our hospital offers a transport facility for all children referred to our PICU. The distances between the referring hospitals and our center range from 15 to $100 \mathrm{~km}$, so air transport is used infrequently. Therefore, the transport unit was developed for use in ground ambulances only. The stand-alone time for the unit should be sufficient for the worse case scenario. In case of a failure of electricity or gas supplies on the ambulance, the stand-alone time is determined as the maximum time from departure from the referring hospital (loading) until arrival in our unit (unloading). According to the distances in our region this time is $60 \mathrm{~min}$. With an extra safety time of $30 \mathrm{~min}$, the stand-alone time of our unit should be $90 \mathrm{~min}$ for all potential patients, from infants up to adulthood. In order to save electrical power and gasses the unit must be compatible with the ambulance supplies (electrical power, air and oxygen) and the referring hospital supplies. The maximum electrical power necessary should not exceed 1200 watts, which is the maximum available by the 220 -volt a.c. equipment of the ambulance. All equipment should be technically reliable, transportable and batteries must be reliable for the time of the demanded power supply. The attending pediatric intensivist, who sits on the left side of the patient in the ambulance, should be able to reach the ventilator, monitor, perfusors and disposables without having to disconnect her/his safety belt. All functions of the equipment including alarms should approach the level of the PICU.

Monitoring during transport should be comparable to that on the PICU with similar vital function monitoring and with similar alarm functions. During transport, a minimum of electrocardiogram, respiratory rate, pulse oximetry and non-invasive blood pressure should be monitored. If indicated, invasive blood pressure, temperature and capnography measurement should be possible. For continuous monitoring we chose the transport component monitor HP mark 1205A (Philips Nederland B.V., Medical Systems, The Netherlands) allowing monitoring of all above listed parameters. The chosen component monitor was identical to that used on the PICU with the advantages that all the components 


\section{Chapter 4}

can be plugged directly into the PICU bedside monitors and the team is used to the functions of the monitor. Point-of-care blood testing is available during transport by the i-STAT blood analysis component M1022A (Philips Medical Systems) and allows the analysis of blood gas, ionized calcium, potassium, sodium, glucose and hematocrit.

As the indication for electric shock therapy in children is rare, a defibrillator was not considered essential in the transport unit. When required during transport the ambulance defibrillator is used.

Ventilatory management during transport should be comparable to the ventilation and alarm functions on the PICU. The same ventilator was chosen as is used on the PICU, not only because of the functions but also to allow a rapid exchange in case of a technical failure. The ventilatory equipment used on the PICU, the servo 300 ventilator (Siemens-Elema AB, Solna, Sweden) is not specially developed for transport.

The requirements for transport are listed in Table 1 (page 68).

\section{B. Argument for the choice of equipment and materials}

However, a ventilatory system for transport suitable for children from $2 \mathrm{~kg}$ up to $100 \mathrm{~kg}$ with diverse diseases is not commercially available. A striking deficiency of specially developed transport ventilators is a reliable alarm function for inspiratory and expiratory volumes.

The servo 300 ventilator has been found to permit the ventilation of children during transport, allowing optimal control. The ventilator consists of two parts, a control panel for tuning the ventilator settings, reading the measured values and giving the alarm functions, and the patient unit. Both parts are connected via a $2.5 \mathrm{~m}$ connecting cable and to an external back-up battery with an operating time of $2 \mathrm{~h}$. With the availability of both oxygen and air during transport it is possible to ventilate the patients with inspiratory oxygen fractions ranging from 0.21 to 1.0. In order to reduce weight we mounted two oxygen and one air cylinder of 2 I each (filling pressure of 200 bar) on the transport unit. Since the stand-alone time of the unit is established to be $90 \mathrm{~min}$, two oxygen cylinders are sufficient in case of a maximum minute volume of $10 \mathrm{I}$, with an inspiratory oxygen fraction of 1.0. All gas cylinders are connected on a pressure regulator. Filling pressures can be read on barometers fitted on the pressure regulator. Working pressure (post-regulator pressure) can be read both for oxygen and air. Since a gas driven (Venturi) suction unit would use too much gas, a suction unit with a 12 volt driven unit with an internal battery with a capacity of at least two h (Premier Suction Unit, Laerdal Medical, Norway) is included. 
All medication for advanced life support, management of all kinds of potential derangements, sedation and further specific needs of the patient is stored in a drawer. This drawer is easily removable for storage in a refrigerator between transports. For the sake of simplicity the medication is not cooled during transport.

A halogen flashlight is present for use in the dark and for the introduction of central venous lines. The flashlight is water-resistant and sparkless for safety reasons.

Our experience taught that during most transports four perfusion pumps were sufficient, in combination with two infusible pressure infusors. The pumps are equipped with internal batteries with two h capacity. The connection points of the syringes are mounted so as to point downwards to avoid gas embolism.

The total amount of electric energy used is 600 watts.

Because of the weight of the system $(180 \mathrm{~kg})$ excluding the patient, a trolley is used with a continuous loading capacity of $200 \mathrm{~kg}$ and a peak loading capacity of 280 kg (Trolley 4003; Stollenwerk, Köln, Germany). If necessary, nitric oxide equipment is available during transport on a separate mobile system.

\section{Description of the transport unit}

A transport unit containing all the equipment and materials required for transport, including the ventilator and gas supplies, was developed with the precondition that these should be readily accessible with optimal view of the patient and the equipment (Fig. 1, page 70).

The transport unit consists of a trolley, a storage compartment covering the whole area of the trolley, and on top of this compartment a mattress and a frame supporting part of the equipment.

In the storage compartment, all equipment and materials not requiring direct access of the team are stored. The frame used allows mounting of all supporting equipment and materials that should be within direct view of the team and demand direct access.

This frame is constructed at the right side of the patient, allowing optimal access to the patient from the left side and at the head. The storage compartment and the frame were specially constructed by Estax techniques (Oss, The Netherlands). The gas supplies were delivered by Medicare-Uitgeest BV (Uitgeest, The Netherlands). 


\section{Chapter 4}

\section{Table 1}

\section{Recommended equipment and materials for pediatric intensive care transport}

\section{Monitoring}

ECG, respiratory rate, pulse oximetry, temperature,

blood pressure non-invasive (cuffs neonatal, infant, child, adult), blood pressure invasive, capnography, point-of care blood testing

\section{Defibrillator}

5-400 J capacity with pediatric and adult paddles

\section{Airway management}

Laryngoscope with blades Miller 0-1 and Macintosh 1-4, Magill forceps (pediatric and adult), endotracheal tubes (uncuffed 2.0-6.0 and cuffed 5.0-8.0), endotracheal tube stylettes, oral airways $0-5$, suction unit and suction catheters, stethoscope,

\section{Ventilatory management}

Chest tubes and Heimlich valve, nebulizer, oxygen delivery devices (nasal cannulas, oxygen masks), artificial huminifider, resuscitation bags (child and adult),

PEEP valve, face masks (infant, child, adult), mechanical ventilator (neonatal, pediatric, adult)

\section{Gas supplies}

Oxygen and air, with pre and post pressure regulator manometer, flowmeter $-15 \mathrm{~L} / \mathrm{min}$ plug-ins for oxygen and air in ambulance and referring hospital

\section{Fluid management}

Intravenous cannulas, intra-osseous needles, central venous lines, infusion pumps, fluids (normal saline, $5 \%$ dextrose),

tubing, needles, syringes

\section{Medication}

Pulmonary:

bronchodilators aerosol, salbutamol for iv, corticosteroids

Circulatory:

adenosine, atropine, calcium chloride, diuretics, dobutamine, dopamine, epinephrine, norepinephrine, amiodarone, lidocaine, sodium bicarbonate, vasodilators

Neurologic:

anticonvulsant, mannitol, muscle relaxants, naloxone, opiate, sedative

Other:

antibiotics, clemastine, colloids, $50 \%$ dextrose, potassium, medication for all possible derangement

\section{Electrical power}

Plug-in connection in ambulance and referring hospital

\section{Other materials}

Adhesive tape, arterial line maintenance system, nasogastric tubes $(6,8,10,12 \mathrm{Fr})$, urinary bladder catheters (infant, child, adult), scissors, alcohol wipes, flashlight, resuscitation chard, patient chard, communication equipment 
The storage compartment consists of an aluminum box, which is $15 \mathrm{~cm}$ high and divided into four sections:

Section I, at the head, containing the patient unit of the Servo 300 ventilator. The connecting ventilator tubes are easy to access with a minimum of distance from the ventilator to the patient's head. Intubation equipment and materials, central venous lines and converters for gas supplies are also stored in this section.

Section II, containing the external backup battery for the Servo 300 ventilator, ventilatory masks, and humidifiers.

Section III, containing the oxygen and air cylinders and resuscitation fluids. The central position of these heavy materials, in sections II and III, is important for the stability of the unit.

Section IV, containing materials for fluid and electrolytes administration, intravenous access (including intra-osseous needles), thoracentesis drains, Heimlich valve and other small materials.

The frame is an aluminum construction that supports the following equipment:

The transport monitor and the halogen flashlight, underneath which is the medication drawer. The control panel of the Servo 300 ventilator is mounted on the frame at the right side to the patient, providing a good view and access for the team. Four perfusion pumps are adjusted adjacent to the control unit of the ventilator. An oxygen flowmeter and an adult and a pediatric resuscitation bag are located just above the patient's head. Oxygen and air plug-ins and the power connection are located at the head of the brancard. A suction unit is placed at the head of the brancard. A total of 8 electrical sockets for 220-volt a.c. with outlet safety plates are installed in the frame. They are connected with fuses. An earth leakage circuit breaker is not installed because it is not necessary in the ambulance and moreover when the unit is connected to the power supply in the referring hospital the circuit breaker of the hospital is in function.

\section{Experience with use of unit}

Pediatricians trained in intensive care perform nearly all transfers of critically ill children from the age of 4 weeks up to 16 years from non-tertiary hospitals to our center. For the past three years we have used the mobile pediatric intensive care transport unit described herein. In our 3 years experience with this transport unit there have been no mechanical problems. During this period we transported over 200 patients, of whom $63 \%$ were intubated and mechanically ventilated. The most common indications for transfer were respiratory insufficiency (50\%) and shock (30\%). The stand-alone time was sufficient 


\section{Figure 1}

The pediatric intensive care transport unit

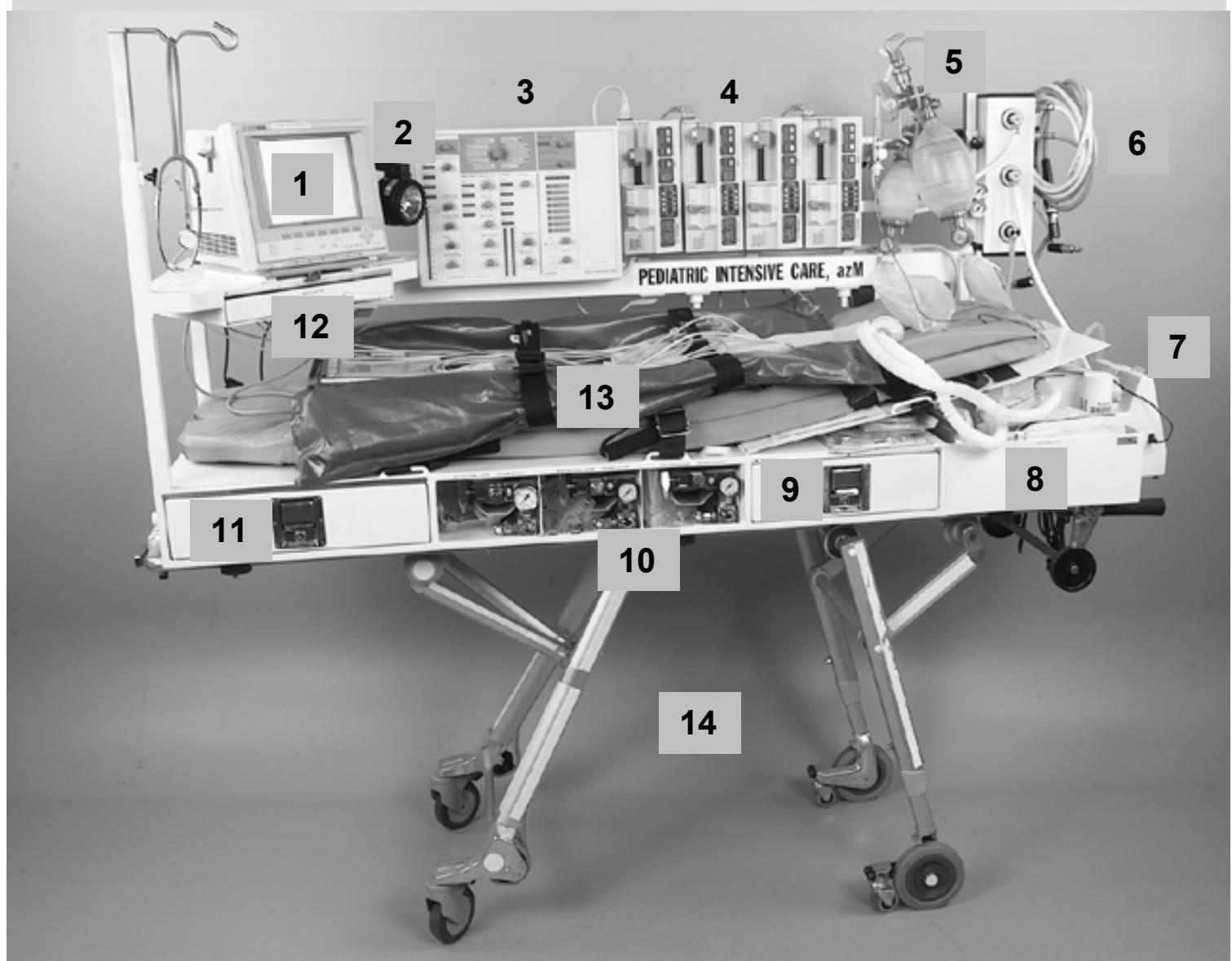

1 monitor

2 flash light

3 control panel servo 300 ventilator

4 perfusion pumps

5 resuscitation bags

6 gas and power supplies

7 suction unit

8 patient unit servo 300 ventilator, materials for intubation, venous access

9 external backup battery servo 300 ventilator

10 oxygen and air cylinders, resuscitation fluids

11 materials

12 medication

13 mattress

14 trolley 
during all transports. Our experience was that all equipment and materials were readily accessible. It appeared that the access to the patient during transport is sufficient for resuscitation, intubation and other necessary interventions. Ventilation and monitoring during the resuscitation and stabilization period in the referring hospital could be commenced and continued with the equipment of the transport unit, as the unit can be placed close to the patient and connected to the hospital supplies for electrical power and gases. In this way, disconnection from the ventilator and monitor during loading the patient onto the transport unit and during the whole transport could be avoided.

\section{Discussion}

With this unit the level of treatment and monitoring that can be given during interhospital transport of critical ill infants and children by our retrieval team is as close as possible to the level on the PICU. The point-of-care blood testing was introduced after experience with a patient with meningococcal septic shock, who had a pulseless electric activity shortly after arrival on the PICU as a result of a severe hypokaliemia $(1.8 \mathrm{mmol} / \mathrm{l})$, despite the suppletion of potassium during transport (2 $\mathrm{mmol} / \mathrm{kg}$ in a 90 minutes period). Resuscitation was successful after the administration of $1 \mathrm{mmol}$ per $\mathrm{kg}$ bodyweight of potassium as a bolus. Before transport the potassium was $2.7 \mathrm{mmol} / \mathrm{l}$. The influence of the point-of-care blood testing during interhospital transport has not yet been published and is now the subject of a prospective observational study.

There are some points of concern regarding the transport unit. The great weight of all equipment, especially the ventilator and the battery (42 kilogram), restricts the weight of the patient for transport and makes the transport unit less easy to handle and more unstable during transport. Weight reduction can be achieved by using less heavy batteries or another (transport) ventilator. The recent introduction of the servo-i (Siemens) seems a good alternative to preserve the optimal ventilatory possibilities and functions while reducing the weight of the equipment. The weight of the servo-i including batteries for at least 2 hours energy supply is over $17 \mathrm{~kg}$ lighter than that in use in the current system. A second point of concern is the control of the body temperature of small infants, while not interfering with optimal observation. Wrapping infants in a silver swaddle and blankets makes it possible to control body temperature even in infants with a bodyweight of $2 \mathrm{~kg}$. The view of and the access to these infants are sub-optimal during transport compared to that achieved in an incubator. However, despite these drawbacks, in our experience the transfer of these infants in the transport unit is safe. 


\section{Chapter 4}

A major issue is the fixation of the patient during transport in a safe way in case the ambulance is involved in an accident. A vacuum mattress, in combination with the standard trolley belts, ensures the fixation of the patients. Safety belts that are now on the market for fixation of the patient during ambulance transport have yet to be examined for the transport of critically ill children.

The total costs of the complete transport unit were approximately $€ 115.000$ (135.000 US\$). The lifetime of the equipment is expected to be approximately 10 years, while the lifetime of the trolley will be 5 years. With approximately 750 to 1000 transports in 10 years, the costs of the mobile pediatric intensive care transport unit will be $€ 115$ to $€ 175$ (135 to 205 US\$) per transport, including technical services.

While the concept of a mobile intensive care unit is not new, in our opinion the features of our pediatric transport unit are more advanced than previously published designs, and are an important step forward in the optimization of the interhospital transport of critically ill pediatric patients approaching the level of care achieved on the PICU. 


\section{References}

1. Pollack mM, Alexander SR, Clarke N, Ruttimann Ue, Tesselaar hM, BACHULIS AC (1991) Improved outcomes from tertiary center pediatric intensive care: a statewide comparison of tertiary and nontertiary care facilities. Crit Care Med 19:150-159

2. GEMKE RJBJ, BONSEL GJ (1995) Comparative assessment of pediatric intensive care: a national multicenter study. Pediatric Intensive Care Assessment of Outcome (PICASSO) Study Group. Crit Care Med 23:238245

3. Pearson G, Shann F, Barry P, Vias J, Thomas D, Powell C, Field D (1997) Should paediatric intensive care be centralised? Trent versus Victoria. Lancet 349:1213-1217

4. GEMKE RJ (1997) Centralisation of paediatric intensive care to improve outcome. Lancet 349:1187-1188

5. BARRY PW, RALSTON C (1994) Adverse events occurring during interhospital transfer of the critically ill. Arch Dis Child 71:8-11

6. Britto J, Nadal S, Maconochie I, LeVIn M, HabiBi P (1995) Morbidity and severity of illness during interhospital transfer: impact of a specialized paediatric retrieval team. BMJ 311:836-839

7. RIDLEY SA, WRIGHT IH, ROGERS PN (1990) Secondary transport of critically ill patients. Hospital Update April:289-300

8. American College Of EMERgency Physicians (1985) Guidelines for transfer of patients. Ann Emerg Med 14:1221-1222

9. RIDLEY S, CARTER R (1989) The effects of secondary transport on critically ill patients. Anaesthesia 44:822-827

10. Runcie CJ, REEVE WR, WALLACE PGM (1992) Preparation of the critically ill for interhospital transfer. Anaesthesia 47:327-331

11. Dawson ADG, BABINGTON PCB (1987) An intensive care trolley. An economical and versatile alternative to the mobile intensive care unit. Anaest Intens Care 15:229-233

12. PARK GR, Johnson S, FERguson A, GRANT D (1982) A mobile intensive care unit based on a standard ambulance trolley bed. $\mathrm{Br} \mathrm{J}$ Anaesth 54:1081-1085 


\section{Point-of-care technology: \\ A portable whole blood}

analyzer leads to therapeutic

interventions during the

interhospital transport of

critically ill children

Vos GD, Ramsay G, Van Goor AAC, Leroy PLJM,

Van Waardenburg DA, Donckerwolcke RAMG

Submitted Sept 2003, European Journal of Emergency Medicine 


\section{Chapter 5}

\section{Abstract}

\section{Objectives}

To investigate the influence of point of care laboratory results (arterial blood gases, ionized calcium, potassium, sodium, glucose, hematocrite and hemoglobin) on therapeutic interventions during interhospital pediatric intensive care transport.

\section{Design}

Prospective observational study.

\section{Settings}

Specialist pediatric intensive care retrieval team of a university hospital, accompanying the interhospital transport of critically ill children.

\section{Subjects}

Pediatric critically ill patients who were referred from a community hospital to a pediatric intensive care of a tertiary center. The retrieval team sampled arterial blood during the time of stabilization in the referring hospital and during transport. All results were documented and for each result the physician of the specialist retrieval team wrote down the influence on the treatment (non, partly, only). He/she specified the kind of intervention.

\section{Results}

Point-of-care blood analyses influenced the therapeutic management in $76.6 \%$ of all blood samples and in $89.9 \%$ of the referred patients. Of all interventions $81.5 \%$ were only based on the laboratory results. The majority of interventions were adjustments of the mechanical ventilation. Point-of-care blood analyses reduced the delay in treatment of potentially life-threatening abnormalities of laboratory results (severe hypokaliemia and low hematocrite).

\section{Conclusions}

During interhospital pediatric intensive care transport point-of-care blood analyses frequently lead to therapeutic interventions, mostly only based on these laboratory results. Some abnormal blood results were potentially life threatening and could not be discovered without point-of-care measurement. We therefore recommend the use of a point-of-care blood analyzer during interhospital intensive care transports, not only for blood gases but also for electrolytes, glucose and hematocrite. 


\section{Introduction}

Point-of care blood testing has been defined as any laboratory test performed outside a central laboratory of the hospital [1]. The interest in this technology is growing especially in emergency rooms, intensive care units and operating rooms. The availability of faster test results may expedite diagnosis and the initiation of treatment, and may have a positive impact on the care of critically ill patients [2-8]. Previous studies of the point-of-care testing in emergency departments have shown varying results on the benefit for patients and cost effectiveness. Point-of-care testing reduces the time of decision making on patient management that were dependent on the results of blood tests and reduces the time of changes in treatment for which timing is considered to be critical. An effect on clinical outcome has never been shown [9]. The accuracy and reproducibility of the i-STAT point-of-care laboratory system is tested in a variety of situations, with adequate correlation to the results of a central laboratory [10-18]. Portable point-of-care blood analyzers have been used in pediatric interhospital transport and helicopter transport $[19,20]$.

The reason for the introduction of the i-STAT point-of-care laboratory system to our mobile pediatric intensive care transport unit was the following case. A six years old boy was referred to our pediatric intensive care unit because of a severe meningococcal septic shock. After stabilization by the referring pediatrician and our specialist retrieval team the patient was transferred. As a result of an hypokaliemia $(2.7 \mathrm{mmol} / \mathrm{l})$ in the referring hospital an intravenous potassium infusion of $1.0 \mathrm{mmol} / \mathrm{kg}$ bodyweight was given in half an hour during the transport, followed by a continuous infusion of $4 \mathrm{mmol} / \mathrm{kg}$ bodyweight in 24 hours. The transport was uncomplicated with a transport time of 45 minutes, but on arrival on our PICU there was an acute cardiac arrest with an electromechanical dissociation. CardioPulmonary Resuscitation (CPR) was started and there was no reaction on fluid resuscitation, epinephrine or other management. Because of the acute onset of the pulseless electric activity without any circulatory detoriation in the period before the circulatory arrest and because of the hypokaliemia on admission, 10 minutes after the start of the CPR an intravenous push of 0.5 $\mathrm{mmol} / \mathrm{kg}$ potassium was given in 30 seconds. During the potassium push the circulation recovered with normalization of the bloodpressure. The serum potassium in the blood sample just before the circulatory arrest was 1.8 $\mathrm{mmol} / \mathrm{l}$. The patient recovered fully. We speculated that this complication might have been prevented if point-of-care blood analysis during transport had been possible. Therefore we studied the influence of point-of-care blood analysis on therapeutic interventions in which timing was considered to be 


\section{Chapter 5}

critical to clinical outcome, during the interhospital intensive care transport of critically ill children.

\section{Materials and methods}

\section{Study design}

Descriptive measures were used to evaluate changes in therapeutic interventions that resulted from the point-of-care blood testing. Data were collected during a five months period between September 2002 and February 2003. The pediatric intensivist of the retrieval team decided the time and the number of the blood samples, performed the point-of-care blood testing and the data collection. The influence of the results of the blood samples on the therapeutic interventions could be the solely reason to perform the intervention, this is noted as "only". In cases that the results of the blood sample did not solely influence the therapeutic interventions, but also other parameters of the patient monitor contributed samples on the therapeutic interventions, this is noted as "partial". During interhospital transport the transport team had monitoring of ECG, respiration, pulse oximetry, end-tidal $\mathrm{CO}_{2}$, invasive blood pressure and non-invasive blood pressure to their disposal. Some therapeutic interventions were defined to be critical. These interventions were those that could not be performed without the blood test results and were potentially life threatening like potassium levels below 2.5 $\mathrm{mmol} / \mathrm{l}$ and hematocrite below $0.20 \mathrm{l} / \mathrm{l}$. The physician was interviewed after the transport to determine the influence of the point-of-care test results during the transport on therapeutic interventions.

\section{Patients}

All patients transferred to our PICU are accompanied during transport by our specialist retrieval team. The blood samples were drawn from an arterial line. The sample time and the sample rate were for the physician of the retrieval team to judge and mainly dependent of the clinical conditions of the patient and the results of previous samples of this patient. All patients in whom blood samples were tested with the point-of-care laboratory-testing device during stabilization by our retrieval team in the referring hospital and during the transport were eligible for inclusion in the study. 


\section{Blood collection and analysis}

The blood samples were tested with the i-STAT point-of-care blood analysis module (M1022A, Philips Medical Systems, The Netherlands), which was integrated in the component monitoring system (M1205A, Philips Medical Systems) used as patient monitor during interhospital transport and is mounted on our mobile pediatric intensive care transport unit. The single-use disposable cartridges (Abbott Laboratories, Illinois, USA) contain a biosensor chip, the entire fluid path and the calibrant solution, stored in a sealed pouch. We used the EG7+ cartridge measuring sodium, potassium, ionized calcium, $\mathrm{pH}, \mathrm{pCO}_{2}, \mathrm{pO}_{2}$ and hematocrite and later in the study the EG8+ cartridge measuring the same as the EG7+ plus glucose. The results are displayed on the liquid crystal display of the component monitor and stored automatically in the monitor. The blood test starts with the introduction of 2-3 drops of whole blood into the cartridge and the module initiates the test procedure automatically when the cartridge is introduced into the module. The results are available after 120 seconds.

\section{Results}

A total of 47 point-of-care blood samples were tested in 27 pediatric patients. The characteristics of the patients are summarized in Table 1.

$\begin{array}{lcc}\text { Table } 1 & & \\ \text { Patient demographics } & \text { Number } & \text { Percentage } \\ & 27 & \\ \text { Number of patients } & 4.9(7.5) & 88.9 \\ \text { Age in years mean }( \pm \text { SD) } & 24 & \\ \text { Mechanical ventilation } & & \\ & & \\ \text { Number of samples } & 9 & \\ 1 \text { sample per transport } & 16 & \\ 2 \text { samples per transport } & 2 & \\ 3 \text { samples per transport } & 47 & 19.1 \\ \quad \text { total number of samples } & & 29.8 \\ \text { Primary admission diagnoses } & 9 & 7.4 \\ \text { Respiratory insufficiency } & 9 & 3.7 \\ \text { Circulatory insufficiency } & 14 & \\ \quad \text { Trauma } & 2 & \\ \quad \text { Neurologic } & 1 & \\ \quad \text { Metabolic } & 1 & \end{array}$




\section{Chapter 5}

There was a wide variation of diagnoses in the group with respiratory insufficiency (ARDS, RSV bronchiolitis, near drowning, meningitis and intoxication with cholinesterase inhibitor). In twelve out of the 14 patients with circulatory insufficiency the diagnosis of septic shock was made, of which 9 were meningococcal septic shock. Three patients were not mechanically ventilated.

The influence of the results of the point-of-care blood samples on the decision to perform therapeutic interventions is given in Table 2. The results are given per blood sample and per patient transport.

\begin{tabular}{|c|c|c|c|}
\hline \multicolumn{4}{|c|}{$\begin{array}{l}\text { The influence of the results of point-of-care blood analysis on the decision for } \\
\text { therapeutic interventions during interhospital pediatric intensive care transport }\end{array}$} \\
\hline & $\begin{array}{l}\text { "Only" } \\
\text { n (\%) }\end{array}$ & $\begin{array}{l}\text { "Partial" } \\
\mathrm{n}(\%)\end{array}$ & $\begin{array}{l}\text { Total number } \\
\mathrm{n}(\%)\end{array}$ \\
\hline $\begin{array}{l}\text { Per sample }(n=47) \\
\text { no interventions } \\
1 \text { intervention } \\
2 \text { interventions } \\
3 \text { interventions } \\
4 \text { interventions }\end{array}$ & $\begin{array}{r}16(34.0) \\
15(31.9) \\
13(27.7) \\
3(6.4)\end{array}$ & $\begin{array}{r}30(63.8) \\
16(34.0) \\
1(2.2)\end{array}$ & $11(23.4)$ \\
\hline $\begin{array}{l}\text { Number of samples with any intervention } \\
\text { Total interventions }\end{array}$ & $\begin{array}{l}31(66.0) \\
50\end{array}$ & $\begin{array}{l}17(36.2) \\
18\end{array}$ & $\begin{array}{l}36(76.6) \\
68\end{array}$ \\
\hline $\begin{array}{l}\text { Per patient transport }(n=27) \\
\text { no interventions } \\
1 \text { intervention } \\
2 \text { interventions } \\
3 \text { interventions } \\
4 \text { interventions } \\
5 \text { interventions } \\
6 \text { interventions }\end{array}$ & $\begin{array}{l}5(18.5) \\
9(33.3) \\
\quad 6(22.2) \\
1(3.8) \\
4(14.8) \\
2(7.4)\end{array}$ & $\begin{array}{r}14(51.9) \\
8(29.6) \\
5(18.5)\end{array}$ & 3 (11.1) \\
\hline $\begin{array}{l}\text { Number of patients with any intervention } \\
\text { Total interventions }\end{array}$ & $\begin{array}{l}22(81.5) \\
50\end{array}$ & $\begin{array}{l}13(48.1) \\
18\end{array}$ & $\begin{array}{l}24(88.9) \\
68\end{array}$ \\
\hline $\begin{array}{l}\text { "Only" There were no other signs that in } \\
\text { intervention than the results from } \\
\text { "Partial" There were other signs that influe } \\
\text { intervention together with the resi }\end{array}$ & $\begin{array}{l}\text { enced the dec } \\
\text { e point-of-care } \\
\text { ed the decisic } \\
\text { from the poil }\end{array}$ & $\begin{array}{l}\text { perform a } \\
\text { analysis } \\
\text { erform a th } \\
\text { are blood a }\end{array}$ & $\begin{array}{l}\text { apeutic } \\
\text { utic } \\
\text { s }\end{array}$ \\
\hline
\end{tabular}

Point-of-care tests influenced treatment in $76.6 \%$ of all samples. Eleven blood samples did not lead to a therapeutic intervention. In $66.0 \%$ of the samples adjustment of treatment was performed solely on the basis of the sample results. In $11.1 \%$ of the patients there was no therapeutic intervention based on the sample results. In $81.5 \%$ of the patients interventions were solely performed based on the results from the i-Stat. Most of the interventions were adjustment of mechanical ventilation. The adjustment of minute ventilation was always based on the results of the blood samples in 
combination with the monitored end-tidal $\mathrm{CO}_{2}$. In ten patients potassium administration was necessary due to hypokaliemia, of whom 2 patients had potassium levels below $2.5 \mathrm{mmol} / \mathrm{l}$. In five patients a blood transfusion was given as a result of the point-of-care results with hematocrite below $0.20 \mathrm{I} / \mathrm{l}$. In two patients blood was already ordered during the transport, both patients with meningococcal septic shock and hematocrite levels of 0.10 and $0.15 \mathrm{I} / \mathrm{l}$ due to severe hemolysis.

\section{Discussion}

We did not test the reliability and reproducibility of the i-Stat point-of-care blood analyzer since many studies have been done in this area. In most studies the results were found to be accurate, precise and correlated with acceptable methods used routinely in the laboratory [5, 10, 14, 16-23]. There have been a few publications concerning a less accurate sample result for hematocrite, calcium, $\mathrm{pH}, \mathrm{PO}_{2}$ and $\mathrm{PCO}_{2}$. The conclusion in one publication was that the use of point-of-care blood analysis couldn't be recommended in a hospital environment where classical instruments can be made available [24]. But on the other hand it is also concluded that it was not of importance that the nationally required quality standards for $\mathrm{Ca}, \mathrm{pH}$, and $\mathrm{Hb}$ were not met because the measured deviation was too small to have clinical relevance [25]. In one publication it was concluded that no real use could be made of values noted for hematocrite [12]. Since there is no possibility to perform these laboratory tests during interhospital transport other than by a point-ofcare blood analyzer and the accuracy is high enough for clinical practice (perhaps with the exception of hematocrite) the i-Stat provides rapid, reliable, and useful data that help to determine therapy for critically ill patients during interhospital transport.

Measurement of various laboratory tests is part of the clinical routine in the intensive care and highly important in the treatment of critically ill patients. Respiratory, circulatory and metabolic therapeutic interventions are supported by blood test results. Point-of-care blood analyses have been shown to reduce the diagnostic and treatment delay in emergency and intensive care units $[3-5,8,9]$ and in units for dialysis [2]. The use of the point-of-care blood analysis during interhospital ambulance transport has only been studied for the influence on mechanical ventilation [19]. The results of these tests are of importance for the treatment of critically ill patients and since the technique is available outside the hospital the patients might benefit from the use of point-of-care blood analysis during interhospital transport. 


\section{Chapter 5}

The use of capnography during interhospital transport is useful in confirming endotracheal tube position of critically ill children [26] and offers the possibility to detect potentially life-threatening problems in ventilated patients during transport [27]. The arterial $\mathrm{CO}_{2}$ measured with the i-Stat gives the opportunity not only to detect life-threatening problems but also to change the minute volume to normalize the blood gas values during transport. The adjustment of the inspired oxygen fraction $\left(\mathrm{FiO}_{2}\right)$ was in most cases based on high arterial $\mathrm{O}_{2}$ pressures $\left(\mathrm{PaO}_{2}\right)$. Before the introduction of the point-ofcare blood analyzer we were not accustomed to reduce the $\mathrm{FiO}_{2}$ during the transport when the oxygen saturation measured by pulse oximetry was $100 \%$. Now we reduce the $\mathrm{FiO}_{2}$ if the $\mathrm{PaO}_{2}$ is $15 \mathrm{kPa}$ or higher. This might diminish the potential oxygen toxicity. In the referring hospital adjustment of mechanical ventilation can also be done more rapidly with the use of the point-of-care blood analyzer as shown in the study of Bhatia, where modification of treatment or adjustment to mechanical ventilation was required in $30 \%$ of transported patients based on blood gas results obtained immediately before departure from the referring hospital. The authors concluded that a portable blood gas analyzer provides rapid, reliable, and useful data that help to determine therapy for critically ill children awaiting interhospital transport [19].

The interventions for hypokaliemia were frequent and can be explained by the high incidence of meningococcal sepsis. In meningococcal sepsis hypokaliemia is commonly seen. The lowest serum potassium was 2.0 $\mathrm{mmol} / \mathrm{l}$ in a patient with an intoxication of cholinesterase inhibitor and in which it was unexpected. Hypokaliemia is potentially life threatening as shown in the case we described in the introduction and is sometimes unexpected. An acute decrease in hematocrite was seen in two patients with meningococcal septic shock. In one case the hematocrite fell from 0.24 to $0.10 \mathrm{l} / \mathrm{l}$ during transport and blood was ordered during the transport since this low hematocrite was potentially life threatening, especially in a patient with septic shock. On arrival in the PICU a blood transfusion could be started immediately. The low hematocrite results correlated well with control samples taken on admission to the PICU.

In conclusion the results of the point-of-care blood analyses lead, in a high percentage of cases to therapeutic interventions. Further most of these interventions are done solely on the basis of these results, and a number of the abnormal blood values were potentially life threatening. We therefore recommend the use of a point-of-care blood analyzer not only for blood gases but also for electrolytes, glucose and hematocrite, during interhospital intensive care transports. 


\section{References}

1. SANTRACH PJ, BuRRITT MF (1995) Point-of-care testing. Mayo Clin Proc 70:493-494

2. GAUlt MH, HARDING CE, DufFetT S, LONGERICH L (1998) i-STAT handheld point-of-care analyzer for dialysis units. Nephron 80:344-348

3. JATLOW P (1993) Point of care laboratory testing in the emergency department. Am J Clin Pathol 100:591

4. Kendall JM, Bevan G, Clancy MJ (1999) Point of care testing in the accident and emergency department: a cost analysis and exploration of financial incentives to use the technology within the hospital. J Health Serv Res Policy 4:33-38

5. MURTHY JN, HICKS JM, SOLDIN SJ (1997) Evaluation of i-STAT portable clinical analyzer in a neonatal and pediatric intensive care unit. Clin Biochem 30:385-389

6. Ng VL, Kraemer R, Hogan C, Eckman D, Siobal M (2000) The rise and fall of i-STAT point-of-care blood gas testing in an acute care hospital. Am J Clin Pathol 114:128-138

7. Papadea C, Foster J, Grant S, Ballard SA, Cate JCt, Southgate WM, PUROHIT DM (2002) Evaluation of the i-STAT Portable Clinical Analyzer for point-of-care blood testing in the intensive care units of a university children's hospital. Ann Clin Lab Sci 32:231-243

8. Parvin CA, Lo SF, Deuser SM, WeAver LG, LeWis LM, Scott MG (1996) Impact of point-of-care testing on patients' length of stay in a large emergency department. Clin Chem 42:711-717

9. Kendall J, Reeves B, Clancy M (1998) Point of care testing: randomised controlled trial of clinical outcome. Bmj 316:1052-1057

10. BINGHAM D, KENDALL J, CLANCY M (1999) The portable laboratory: an evaluation of the accuracy and reproducibility of i-STAT. Ann Clin Biochem 36 ( Pt 1):66-71

11. ERICKSON KA, WILDING P (1993) Evaluation of a novel point-of-care system, the i-STAT portable clinical analyzer. Clin Chem 39:283-287

12. FeUILLU A, MoRel I, Mollard JF (2002) Evaluation of portable point of care instrument: the i-Stat . Report of 7,000 analyses. Ann Biol Clin (Paris) 60:153-164

13. JAhR JS, LURIE F, Driessen B, TANG Z, Louie RF, Kost G (2003) Validation of oxygen saturation measurements in a canine model of hemoglobin-based oxygen carrier infusion. Am J Ther 10:21-28

14. Mock T, MORRISON D, YATSCOFF R (1995) Evaluation of the i-STAT system: a portable chemistry analyzer for the measurement of sodium, potassium, chloride, urea, glucose, and hematocrite. Clin Biochem 28:187-192 
15. OZAKI J, TANimoto N, Kuse H, HoRI M (2000) Comparison of arterial blood gases and acid-base balance in young and aged beagle dogs, with regard to postprandial alkaline tide. J Toxicol Sci 25:205-211

16. Pidetcha P, ORNVICHIAN S, Chalachiva S (2000) Accuracy and precision of the i-STAT portable clinical analyzer: an analytical point of view. J Med Assoc Thai 83:445-450

17. Sediame S, Zerah-LANCNer F, d'Ortho MP, Adnot S, Harf A (1999) Accuracy of the i-STAT bedside blood gas analyzer. Eur Respir J 14:214-217

18. Verwaerde P, Malet C, Lagente M, de la Farge F, Braun JP (2002) The accuracy of the i-STAT portable analyzer for measuring blood gases and $\mathrm{pH}$ in whole-blood samples from dogs. Res Vet Sci 73:71-75

19. Bhatia N, SiLVER P, QUINN C, SAgY M (1998) Evaluation of a portable blood gas analyzer for pediatric interhospital transport. J Emerg Med 16:871-874

20. BurRitt MF, SANTRACH PJ, Hankins DG, HeRr D, NeWTON NC (1996) Evaluation of the i-STAT portable clinical analyzer for use in a helicopter. Scand J Clin Lab Invest Suppl 224:121-128

21. Martin J, Messelken M, Hiller J, Dieterle-Paterakis R, Krier C, MILEWSKI P (1996) Mobile blood gas and laboratory monitoring. A new technology in clinical routine. Anasthesiol Intensivmed Notfallmed Schmerzther 31:309-315

22. Prause G, Kaltenbock F, Doppler R (1998) Preclinical blood gas analysis. 2. Experience with three blood gas analyzers in emergency care. Anaesthesist 47:490-495

23. TSCHUDI PR (1998) Evaluation of the portable blood analyzer i-STAT. Schweiz Arch Tierheilkd 140:507-512

24. Sachs C, Finetti P, Rabouine P, Abdoulaye F (2002) Analytical performances of the i-STAT portable clinical analyzer for the measurement of PO2 and PCO2. Ann Biol Clin (Paris) 60:411-420

25. Schneider J, Dudziak R, WestPhal K, Vettermann J (1997) The iSTAT analyzer. A new, hand-held device for the bedside determination of hematocrite, blood gases, and electrolytes. Anaesthesist 46:704-714

26. BHENDE MS, KARR VA, WILTSIE DC, ORR RA (1995) Evaluation of a portable infrared end-tidal carbon dioxide monitor during pediatric interhospital transport. Pediatrics 95:875-878

27. Ruckoldt H, MarX G, LeuWer M, PANning B, Piepenbrock S (1998) Pulse oximetry and capnography in intensive care transportation: combined use reduces transportation risks. Anasthesiol Intensivmed Notfallmed Schmerzther 33:32-36 
General discussion and future perspectives 


\section{General Discussion}

Since the first publications on centralization by Pollack in the early 1990s pediatric intensive care units in tertiary facility centers play an important and increasing role in the care for critically ill infants and children. This centralization leads to better outcome, quality of care, and the possibility of better management and organization of these units. Although the centralization of pediatric intensive care in The Netherlands made progress in the last decades the following problems are threatening this process:

1. The lack of sufficient pediatric intensive care beds in tertiary centers,

2. The reluctance of physicians in community hospitals to refer critically ill children

3. The organization of safe transportation of these children on a regular basis.

\section{The lack of sufficient pediatric intensive care beds in tertiary centers}

Pediatric intensive care is a low volume, high cost specialty, which demands a special level of skills and training of medical and nursing staff and the availability of specialist equipment. In times of worldwide economic recession resources for healthcare and in particular intensive care are scarce. Also medical and nursing staff is hard to find. Physicians willing to follow a training for pediatric intensive care are hard to find, and frequently they relocate to community hospitals after finishing their training[1].

To solve the problem of the shortage in pediatric intensive care beds, a national coordination is necessary to implement the policy framework of 2002 [2]. This framework includes the expansion of pediatric intensive care beds. The coordination should monitor closely the number of pediatric intensive care beds required in The Netherlands, but also the number of tertiary facility centers with a pediatric intensive care unit. Historically the number of tertiary facility centers is eight, since all eight university medical centers developed their own unit. This was partly related to the policy that training in pediatrics should include an obligatory, short training in pediatric intensive care. Although the number of tertiary facility centers with a pediatric intensive care is more than sufficient, the number of beds in these centers still has to increase to fulfill the needs. Increasing the number of centers with a PICU would give raise to insufficient development and maintenance of skills, in at least some centers, because of an insufficient volume of pediatric intensive care patients per center resulting in impoverishment of the current high standards in these pediatric intensive care units. 
The reluctance of physicians in general hospitals to refer critically ill children

To convince the physicians in general hospitals of the advantages for the critically ill child to be referred to a tertiary facility center is preferable to obliging them by regulation. To achieve this, a more active role for the Dutch Pediatric Association is necessary. Guidelines for admission and discharge policies, as well as general criteria used for transfer, have to be developed and be based on a consensus opinion acknowledged by physicians and nurses. The purpose of these guidelines is to provide a reference for admitting and subsequently discharging critically ill children. Each tertiary facility center has to adapt and modify these guidelines into its own policy and procedures based on the scope of the critical illnesses seen in that center. Interhospital transfer arrangement of each center has to be assessed within their referring region. The Guidelines for regionalization of services for critically ill or injured children [3], the Guidelines for developing admission and discharge policies for the pediatric intensive care unit [4], and the Guidelines and levels of care for pediatric intensive care units [5] of the American Society of Critical Care Medicine and the American Academy of Pediatrics may provide a basis.

The reluctance might not only be caused by the fact that some pediatricians do not endorse the guidelines for referral, but also by the fact that, at least in The Netherlands, general pediatricians have to organize and accompany a substantial number of the interhospital transports them-selves. From their point of view the assessment that not transferring these patients to a tertiary facility might be less threatening for the patients than a transfer under uncontrolled conditions is understandable. Probably the best way to achieve the goal that all pediatric patients needing intensive care are referred to tertiary facility centers is a pediatric interhospital transport facility covering the whole country.

Unless specialist retrieval teams become an important part of the organization of the centralization of pediatric intensive care, the death of a child while being transferred to a tertiary facility center and accompanied by inexperienced personnel from the referring hospital, will inevitably lead to calls to reverse the regionalization process. 


\section{The organization of safe transportation of children}

Safe interhospital transport of critically ill children demands highly skilled physicians and nurses in the retrieval teams, and the availability of equipment and materials to deliver care of the patient during transfer as close as possible to the level on the pediatric intensive care. Therefore, our studies have focused on the problems encountered during pediatric intensive care transport accompanied by non-experienced physicians.

From the patient's point of view the results in this work are in accordance with other studies. In a recently published prospective study in South Africa transfers accompanied by paramedic staff showed technical adverse events in $36 \%$ of the transports, clinical adverse events in $27 \%$, and critical adverse events in $9 \%$ [6]. Retrieval teams staffed by intensive care physicians showed no adverse events. Technical adverse events did not increase mortality. Non-survivors were more likely to develop shock $(32 \%)$ or hypoxia $(26 \%)$ during transfer than survivors ( $10 \%$ and $11 \%$, respectively).

The high incidence of missing data in our study was disappointing and was one of the major concerns in the study. Although a significant effort was made to collect all data it seemed very hard to get them. The conclusion is drawn that such studies are only possible in future if data collecting teams can be sent out to all participating centers or by better collaboration.

Based on published studies and own work, we may come to the conclusion that there is sufficient evidence that specialized pediatric transport service will result in fewer technical errors than non-specialized transport, also less complications and better outcomes for these children.

From the point of view of the general pediatricians the results from our survey confirmed the hypothesis that these transports were burdening and stressful. The reluctance of general pediatricians to participate in an active policy to change the current state of transport is surprising. From the available literature, showing less complications and a better outcome when transports are accompanied by specialist retrieval teams and the results from our survey, we would expect that pediatricians would exert more pressure on tertiary facility centers and the government to improve the current state of pediatric interhospital intensive care transport. Surely there are no valid excuses for the lack of organization of specialist retrieval teams for critically ill children in The Netherlands. Not only the general pediatricians would feel more at ease with such a system but also the critically ill children would achieve a better outcome. After the implementation of a regular transport facility in The Netherlands in the coming years the changes in burden and stress and the (dis)satisfaction with this facility under general pediatricians might be the subject of a new survey. It would also be interesting to study the feelings of burden and stress of personnel 
of the transport teams in the same survey, and to look at the impact of this facility on the workload of PICU personnel.

A safe transport also demands the availability of equipment and materials to perform adequate intensive care during these transfers. The development of the pediatric intensive care transport unit described in this work significantly improved the level of transport delivered by our retrieval team. The disadvantages mentioned in the manuscript, such as the weight, the difficulty to control the temperature of very small infants, and the fixation of the patient on the unit demands further developments. There is also concern about the safety of the team in case the ambulance should be involved in an accident. Therefore, an initiative has been taken to develop a new pediatric intensive care transport unit, jointly with all the pediatric intensive care units of the eight tertiary facility centers in The Netherlands, their departments of Medical Physics, the Mobile Intensive Care Unit (MICU) for adult transport in Amsterdam, Heli Holland (a helicopter provider in The Netherlands), and the Technical University Eindhoven. Also ambulance services and the industry will be involved in this development. With the support of the Cedric Paulussen Foundation (Maastricht) several sponsors for the project have been found such as Nuts-Ohra Foundation (Driebergen), the Lions Club Maastricht Mondial and the University Hospital Maastricht (azM). The new unit will be constructed on a modular base, be useable in standard ground ambulances, and tested in crash tests up to at least $10-G$ forces and preferably $20-G$ forces. In the development procedure the members of the specialized retrieval teams will decide on the system requirements, while engineers and technicians will develop and construct the unit.

Since point-of-care blood testing proved to be of importance in therapeutic interventions during interhospital transport it will be standard equipment on future transport units.

Bringing specially constructed intensive care ambulances on the road, which is preferable, would demand excessive financial resources and a choice has to be in balance with overall health priorities. Therefore, it is our opinion that the new pediatric intensive care transport unit has to fit in the standard ground ambulances with minimal adaptation as long as specially developed intensive care ambulances are not yet at our disposal. 


\section{Future perspectives of pediatric interhospital intensive care transport in The Netherlands}

The Ministry of Healthcare, the Inspector of Healthcare and the Dutch Pediatric Association have subscribed and stated the necessity of a well organized pediatric interhospital intensive care transport system in The Netherlands covering the whole country. The working group of Pediatric Intensive Care (working group of the Dutch Pediatric Association) has drawn up guidelines for the development of a national wide transport facility for critically ill children.

Risk to the patient during transport can be minimized through careful planning, use of appropriately qualified personnel, and selection of appropriate equipment. Ideally, a dedicated, specially trained transport team should perform all critical care transports, but it has to be recognized that this is not always feasible.

Since pediatric intensive care is centralized in the eight university medical centers, and given the relative low incidence of critically ill children, it is not to be expected that pediatricians in the community hospitals will develop and maintain experience in the interhospital transport of these children. Therefore the starting-point has to be that these transports should be organized and performed by retrieval teams from the tertiary facility centers. These teams may also play an important role in the stabilization of critically ill patients because of their expertise in the field of pediatric intensive care. These facts demand a rapid availability of these teams. The best solution for a nation wide organization with a rapid availability is a regional organization, where a tertiary facility center with a PICU provides not only the transport of critically ill children in that region, but also participates in training of advanced pediatric life support in the community hospitals.

Since it is to be expected that there will be times that a specialized transport team will not be available for interhospital transports, or the patients condition demands immediate transfer, each hospital needs to develop contingency plans utilizing locally available resources for those instances when the referring facility will have to effect the transport. Regional partition of The Netherlands is proposed and should be implemented as soon as possible. All PICU centers have initiated further development of their transport services to come to a routine transport facility. The time that the end-point of this development will be reached is mainly dependent on the medical and nursing manpower of the PICUs and the availability of ambulance services. 


\section{Life support on admission}

The medical and nursing care in the first period directly after admission in the initial hospital, and before the arrival of a retrieval team, has to be covered by the referring hospital according to the Advanced Pediatric Life Support (APLS) [7]. To achieve this, the referring hospitals have to train their medical and nursing staff, and they must have the availability of equipment and materials necessary for APLS. The PICU center might offer a substantial consultative support. The quality of APLS in the referring hospital is the responsibility of the hospital itself.

\section{Decision for transfer}

The decision to transfer a patient is the responsibility of the attending physician at the referring hospital. This decision depends on the clinical condition of the patient and the expected progress of the disease, the level of care that can be given in the referring hospital and also on the criteria for transfer. All pediatric patients meeting the criteria for referral to a PICU should be transferred.

Once the decision to transfer has been made, it should be initiated as soon as possible. Resuscitation and stabilization should begin at the admission in the referring hospital, and might be continued by the transport team when they arrive in the referring hospital. The patient's problems may be such that stabilization may only be possible at the receiving hospital.

Good medical practice requires that a competent patient or the legally authorized representative of an incompetent patient give informed consent prior to interhospital transport. This must include a presentation of the risks vs. benefits of the transport with documentation in the medical record. If circumstances do not allow for the informed consent process, then both the indications for transport and the reason for not obtaining consent must be documented in the medical record.

\section{Call for referral}

The referring physician must contact a physician at the receiving hospital who is authorized to admit patients. In this first contact the patient's condition is described, and advice about stabilization prior to the transport can be obtained. The referring specialists can contact the PICUs in their region on a regular basis. The possibility to contact the PICUs has improved since the introduction of an emergency phone number on these units for the referring specialists. The 


\section{Chapter 6}

physician at the receiving hospital must have accepted the patient and confirmed that appropriate resources are available at the receiving hospital before the transport begins.

The tertiary facility centers are responsible to find a free PICU bed in another center if there is no bed on their own PICU available. In 2002 the information on available PICU beds in the tertiary facility centers in The Netherlands has improved by the introduction of a national webpage that provides information of free beds and phone numbers of all PICUs. This webpage is updated at least once a day.

\section{Transport organization}

In the near future a specialist retrieval team of one of the PICUs will accompany the transport of all pediatric patients meeting the criteria for transfer, except in conditions where the problems of the patients require immediate transfer. All transfers performed by ground ambulance demands that the complete ambulance team (paramedic and driver) is available.

The organization is regionalized, covering the whole country. The PICUs of the eight tertiary facility centers are responsible for the organization and the performance of the interhospital pediatric intensive care transports in their region. To cover both the supervision of the patients admitted on the PICU and the transports, the manpower of both physicians and nurses of the PICUs should be sufficient.

The PICUs are responsible for the maintenance of the equipment and materials for these transports.

The ambulance services that are involved with these transports, are confronted with a substantial and growing number of transports with a long duration, since the average transport time in pediatric interhospital transport is five hours mainly due to the stabilization time. The annual number of transports per region is estimated to be 200 . This has an influence on the number of teams available on a continuous basis and thus on the manpower necessary for these services. Most transports will be performed by ground ambulance since the distances in The Netherlands do not demand helicopter transport. Only in approximately 5 to 10 percent of the transports, in cases of long distance transport or heavy traffic, helicopter transport might be of benefit for the patient. Using the helicopter of the Mobile Medical Team (MMT), in those centers having the availability might diminish the arrival time of the transport team in the referring hospital. This option can be used in cases where urgent presence of the transport team is desired for the stabilization of the patient. After stabilization the transfer can be performed by ground ambulance. 


\section{Transfer report and transport record}

Both the report by the referring facility to the transport team and the report of the transport team to the receiving PICU should be harmonized for the whole country. Guidelines and protocols have to be utilized.

The number of pediatric interhospital intensive care transports, the reasons for transfer and the duration of the transports are important data to have insight into the necessary infrastructure for pediatric retrieval teams in the tertiary facility centers. Data of interventions by these retrieval teams prior to the transport, the severity of illness scores prior and directly after the transport, and of complications during transport are important to control and improve the quality of these transports. Therefore, a central database for pediatric interhospital intensive care transports is necessary.

\section{Medical legal and insurance issues}

Retrieval teams of the tertiary facility centers will have an important role in the medical treatment of the patient in the referring hospital and during the transport. During all transports the same regulations for professional liability insurance as in the tertiary facility center should apply to the personnel of the transport team. Also medico-legal issues should be the same as in these centers.

Interhospital intensive care transport is mostly performed under emergency conditions, which expose retrieval teams to a higher risk for car accidents. Therefore, disability insurance has to be guaranteed for the transport team during transport.

\section{Final conclusions}

The centralization of pediatric intensive care in The Netherlands has to be further developed by the expansion of PICU beds in the eight tertiary facility centers and the application of the guidelines for referral of critically ill children. Professional, fully equipped retrieval teams should be organized on a permanent, 24-h per day basis, staffed by specialists trained in pediatric intensive care and intensive care transport. For the Dutch situation the best organization is by regionalization, where each PICU is responsible for the organization and performance of the transports in their region. This organization has recently been proposed and will be further developed in the coming years. PICU staff and ambulance services need to be sufficiently staffed to comply with this organization. The referring hospital is responsible for the advanced life support from admission until a specialist retrieval team has arrived. 


\section{Interhospital transfer algorithm}

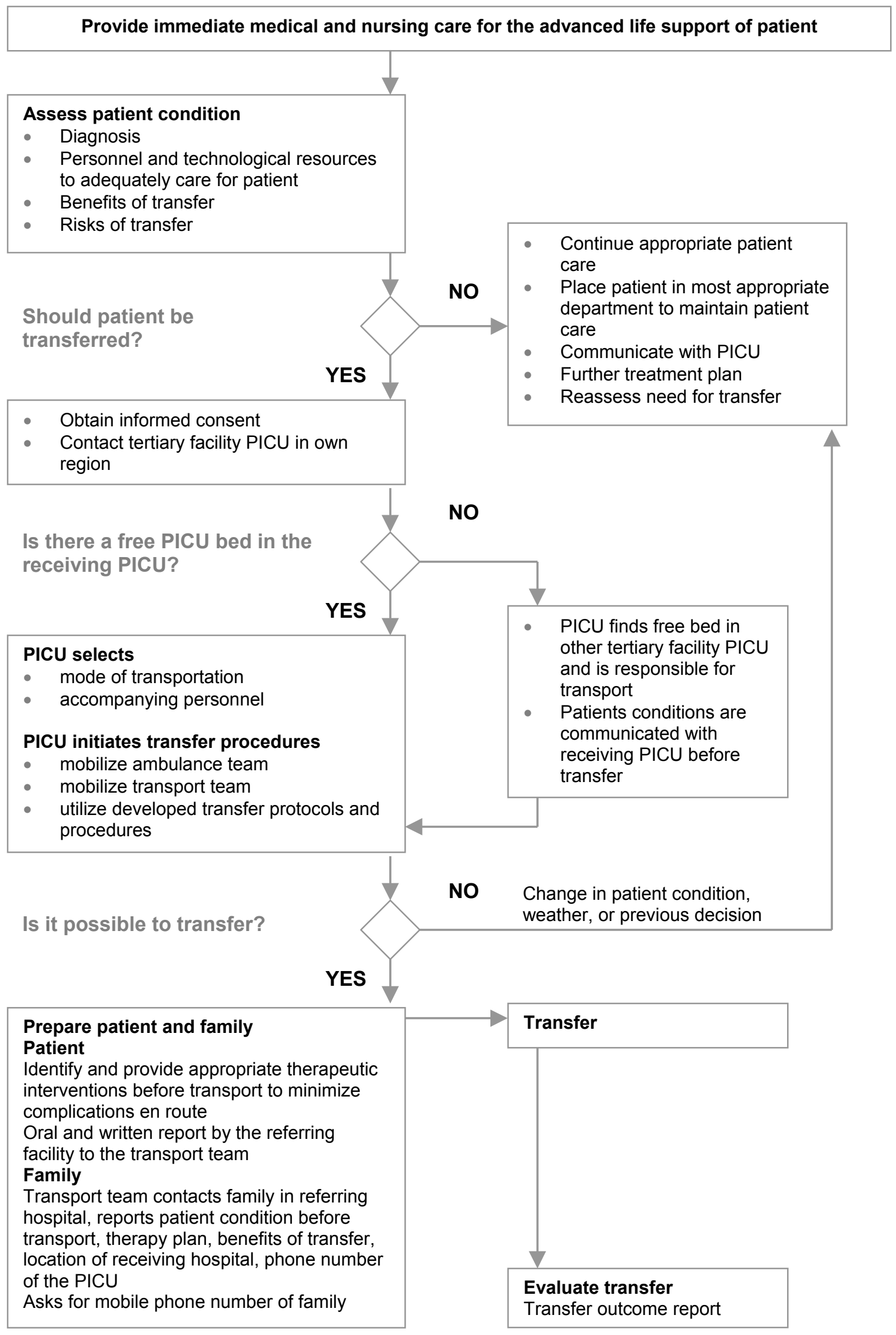




\section{References}

1. OudEn DEN AL (2001) Pediatric Intensive Care in The Netherlands, inquiry report of the Inspector of Health Care, in www.igz.nl

2. Policy pediatric intensive care units (Beleidsvisie pediatrische intensive care units). 2002

3. American Academy of Pediatrics, Committee on Pediatric Emergency Medicine, American College of Critical Care Medicine, Society of CRITICAL CARE MEDICINE (2000) Consensus report for regionalization of services for critically ill or injured children. Pediatrics 105:152-155

4. Society of Critical Care Medicine, American College of Critical Care Medicine, Committee on Hospital Care of the American Academy of PEDIATRICS (1999) Guidelines for developing admission and discharge policies for the pediatric intensive care unit. Pediatric Section Task Force on Admission and Discharge Criteria. Crit Care Med 27:843-845

5. AMERICAN ACADEMY OF PEDIATRICS (1993) Guidelines and levels of care for pediatric intensive care units. Crit Care Med 21:931-937

6. Hatherill M, Waggie Z, Reynolds L, ARgent A (2003) Transport of critically ill children in a resource-limited setting. Intensive Care Med 29:1547-1554

7. Advanced Life Support Group (2001) Advanced Paediatric Life Support: The practical approach. 3rd ed. London: BMJ Books, 2001. 
Summary

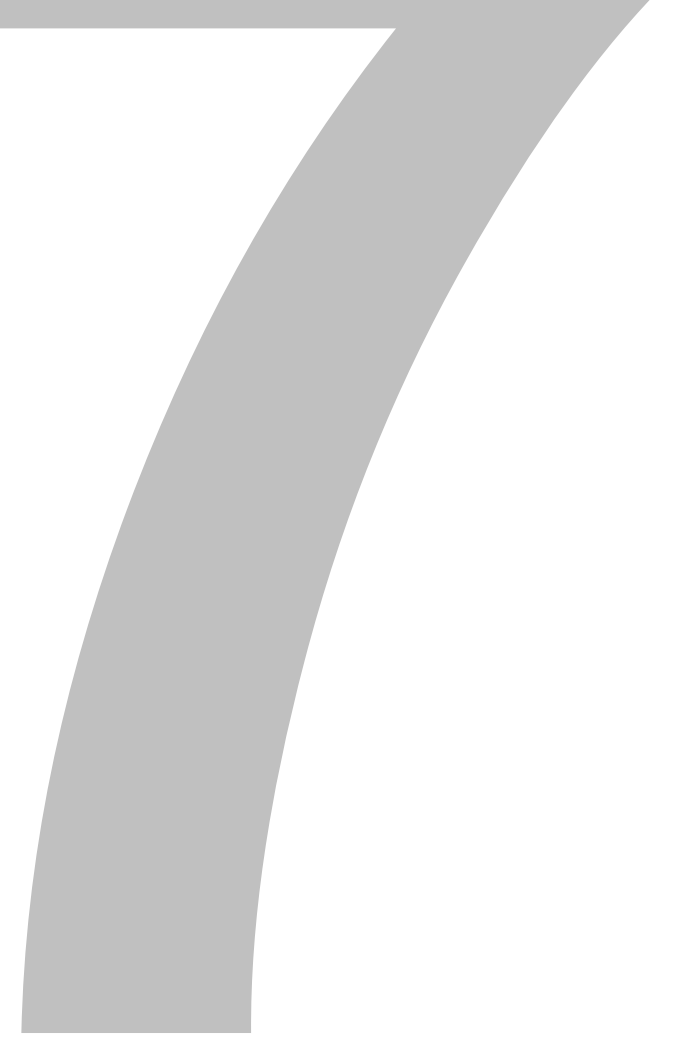




\section{Chapter 7}

Recent developments in providing intensive care for children favor centralization of care in tertiary centers. There is ample evidence that critically ill children show a better clinical outcome when treated in tertiary pediatric intensive care units than when treated in other pediatric centers or in intensive care units of general hospitals. Pediatric intensive care is a low volume, high cost specialty, demanding special skilled medical and nursing staff and specialist equipment. During the last decades the pediatric intensive care has been centralized and further developed in the eight university hospitals in The Netherlands, although there is still a substantial number of patients who meet the criteria for transfer, but are not referred. This situation might improve if more PICU beds are available, the criteria for transfer are followed and the interhospital transport of these critically ill children is well organized. The trend towards centralization of pediatric intensive care leads to a growing number of interhospital pediatric intensive care transports. Since it concerns critically ill children the care during the transfer should be as close as possible to the level of the tertiary pediatric intensive care. The principles of safe transfer of these patients demand experienced staff, appropriate equipment and extensive monitoring, careful stabilization prior to the transport and full view of and access to the patient and equipment (Chapter 1 ).

Although there is evidence, that specialist retrieval teams have a better outcome of transport of critically ill patients regarding mortality, morbidity and complications, and despite the guidelines for interhospital intensive care transport available in the literature, two thirds of all critically ill children in The Netherlands are still accompanied during their interhospital transports by the referring physicians, who are not trained in pediatric intensive care and intensive care transport. During pediatric intensive care transports in The Netherlands accompanied by non-trained referring specialists there appears to be a higher incidence of complications, specialized equipment is more often not available and more acute interventions are required upon arrival in the PICU compared to transports by specialized retrieval teams. On the other hand these specialized retrieval teams from the PICU's perform more interventions prior to the transport and take more time to stabilize the patient (Chapter 2).

Pediatricians of general hospitals in The Netherlands appear to be satisfied with current specialist retrieval teams if these teams are available in their region and highly dissatisfied if these teams are not available. Many nontrained specialists consider these transports burdening tasks with a high workload, and they feel insecure during these transports, especially if they have insufficient knowledge of the transport equipment (Chapter 3 ). 
It is generally accepted that instability of the patient and complications during transport are minimized by optimal resuscitation and stabilization before transport, and by avoiding interruptions in ventilation and monitoring en route. Therefore specialized pediatric retrieval teams must provide all equipment and materials necessary for advanced life support and emergency treatment for children of all ages and body weights. A major problem is the storage of the equipment and materials in such a way that these are readily accessible and optimally placed for patient monitoring. Mobile Intensive Care Units have been described for use in ambulances for the transport of adult patients, but not for pediatric patients. Therefore a mobile pediatric intensive care transport unit, containing all equipment and materials required for transport, and based on a standard ambulance trolley, was developed jointly by the pediatric intensivists and nurses of our PICU, instrumentation engineers of our hospital and personnel of the ambulance service (Chapter 4). This unit however shows limitation in the access to the patient during the stabilization prior to the transport and is not sufficiently safe in a crash situation. Therefore a new mobile intensive care transport unit is now being developed in a collaboration of all Dutch tertiary facility centers, ambulance services, technical university and industries.

We recommend the use of a point-of-care blood analyzer during interhospital intensive care transports, not only for blood gases but also for electrolytes, glucose and hematocrit. This recommendation is supported by a study showing that during interhospital pediatric intensive care transport point-of-care blood analyses frequently lead to therapeutic interventions, mostly only based on these laboratory results. Some abnormal blood results were potentially life threatening and could not be discovered without point-of-care measurement (Chapter 5).

The benefit of the centralization of the care of critically ill infants and children in tertiary pediatric intensive care units can only be achieved if the risks of the transfer are minimized. Professional specialist retrieval teams deliver transport care with better stabilization, less complications and with better outcome in comparison to transports accompanied by referring specialists not trained in intensive care and intensive care transport. A nationwide organization for transfers on a regular basis and with rapid availability can be achieved by a regional organization, where a tertiary facility center with a PICU provides not only the transport of critically ill children in that region, but also participates in training of the advanced pediatric life support in the community hospitals. Successful regionalization of pediatric intensive care depends mainly on an effective and responsive infrastructure for transporting critically ill children. The infrastructure must be developed around the needs of the patients and the 


\section{Chapter 7}

referring hospitals. The best way to achieve this in The Netherlands is by regionalization, where the referring hospital is responsible for the first treatment of the patient according to the advanced pediatric life support guidelines and the tertiary facility centers are responsible for the interhospital transport. The eight tertiary facility centers have started with the implementation of this organizational structure. The major problem hindering this development is the shortage of pediatric intensive care medical and nursing personnel and ambulance personnel. Medico-legal issues and insurances of the transport team have to be determined. To control and improve the quality of interhospital intensive care transport a national database of transport records is necessary (Chapter 6).

The centralization of pediatric intensive care in The Netherlands has to be further developed by the expansion of PICU beds in the eight tertiary facility centers and the application of the guidelines for referral of critically ill children. Professional, fully equipped retrieval teams should be organized on a permanent, 24-h per day basis, staffed by specialists trained in pediatric intensive care and intensive care transport. For the Dutch situation the best organization is by regionalization, where each PICU is responsible for the organization and performance of the transports in their region, and the referring hospital for the advanced life support from admission until a specialist retrieval team has arrived. In this way an optimization of care for critically ill children in The Netherlands can and will be achieved. 
Samenvatting

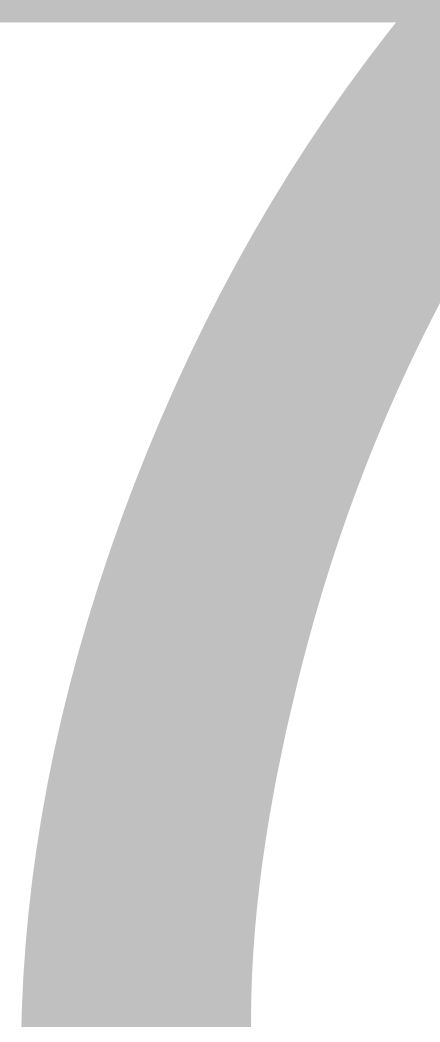


Recente ontwikkelingen op het gebied van de pediatrische intensieve zorg vereisen een centralisatie in topklinische centra. Er bestaat voldoende bewijs dat kritisch zieke kinderen behandeld op pediatrische intensieve zorg afdelingen (PICU's) een betere kans op overleving en herstel hebben dan kinderen behandeld in algemene ziekenhuizen. De pediatrische intensieve zorg is een specialisme met een geringe omvang en hoge kosten, die speciaal opgeleid medisch en verpleegkundig personeel en specialistische apparatuur vereist. In Nederland is in de laatste decennia deze zorg gecentraliseerd en verder ontwikkeld binnen de acht universitaire ziekenhuizen, hoewel nog een aanzienlijk aantal kinderen, die voor overplaatsing in aanmerking komen, niet worden overgeplaatst naar deze centra. In deze situatie kan verbetering optreden indien het aantal bedden op de PICU's wordt uitgebreid, de richtlijnen voor overplaatsing worden opgevolgd en het interklinische transport van deze kritisch zieke kinderen goed georganiseerd wordt. De tendens naar centralisatie leidt tot een toename van het aantal interklinische transporten. Aangezien het hier gaat om kritisch zieke kinderen dient de kwaliteit van zorg voor deze kinderen tijdens het transport zoveel mogelijk die van de PICU te benaderen. Veilig transport van deze patiënten vereist een goed opgeleid en ervaren team van medici en verpleegkundigen, juiste beademingsapparatuur en uitgebreide bewakingsapparatuur. Vooraf aan het transport dient de patiënt gestabiliseerd te worden en tijdens de gehele overplaatsing dient er voldoende zicht op en toegang tot de patiënt te zijn (hoofdstuk 1).

Hoewel er in de literatuur aanwijzingen zijn dat specialistische transportteams betere resultaten boeken ten aanzien van sterfte, evolutie van ziekte en complicaties en ondanks het feit dat richtlijnen aangaande het transport van patiënten die intensieve zorg behoeven voor handen zijn, wordt in Nederland ongeveer tweederde van de kinderen niet door dergelijke teams begeleid tijdens hun transport. Deze kinderen worden begeleid door de verwijzend medisch specialist, die meestal niet opgeleid is op het gebied van pediatrische intensieve zorg en intensieve zorg tijdens transport. In Nederland wordt tijdens het transport van kritisch zieke kinderen onder begeleiding van onervaren medisch specialisten een hoger aantal complicaties gemeld in vergelijking met specialistische transportteams. Tijdens deze transporten beschikken deze medisch specialisten vaak niet over de apparatuur en materialen noodzakelijk voor transporten van patiënten die intensieve zorg nodig hebben en bij aankomst op de PICU zijn in een hoger percentage acute ingrepen noodzakelijk. Gespecialiseerde transportteams van de PICU's voeren meer ingrepen uit voorafgaande aan het transport en nemen meer tijd voor stabilisatie van de patiënt (hoofdstuk 2).

Kinderartsen van algemene ziekenhuizen in Nederland zijn tevreden met de specialistische transportteams als zij deze ter beschikking hebben in hun regio en ontevreden als deze teams niet beschikbaar zijn. Veel medisch specialisten zonder training op het gebied van pediatrische intensieve zorg beschouwen deze transporten als een zware taak en voelen zich onzeker tijdens deze transporten met name als zij weinig kennis hebben van de werking van eventueel beschikbare apparatuur (hoofdstuk 3 ). 
Het wordt algemeen aangenomen dat instabiliteit van de patiënten en complicaties tijdens transport voorkomen kunnen worden door optimale resuscitatie en stabilisatie vooraf aan het transport en door voorkoming van onderbreking van beademing en bewaking tijdens het transport. Specialistische intensieve zorg transportteams voor kinderen moeten de beschikking hebben over apparatuur en materialen die noodzakelijk zijn voor de behandeling en bewaking van kinderen van alle leeftijden en lichaamsgewichten. Een belangrijk probleem daarbij is de wijze waarop de apparatuur en materialen kunnen worden meegenomen zodanig dat zij goed bereikbaar en zichtbaar zijn. Mobiele intensieve zorg transport units voor volwassenen zijn beschreven, maar niet voor kinderen. Daarom is door de PICU van het azM in samenwerking met instrumentele dienst en de ambulancedienst een transport unit ontwikkeld waarop alle apparatuur en materialen op overzichtelijke wijze geplaatst kunnen worden (hoofdstuk 4). Deze unit kent echter beperkingen in de toegankelijkheid tot de patiënt tijdens de stabilisatiefase vooraf aan het transport en lijkt onvoldoende veilig voor patiënt en transportteam bij een eventueel ongeval met de ambulance. Derhalve wordt een nieuwe intensieve zorg transport unit ontwikkeld in samenwerking met alle Nederlandse topklinische centra, ambulancediensten, technische universiteit en industrie.

Het gebruik van een bloedanalyse apparaat tijdens transporten van intensieve zorg patiënten wordt door ons aanbevolen, niet alleen voor de bepaling van bloedgassen maar ook van elektrolyten, glucose en hemoglobine gehalte. Deze aanbeveling is gebaseerd op de resultaten van een studie waarbij tijdens transporten de uitslagen van bloedonderzoek hebben geleid tot een hoge frequentie van interventies, meestal gebaseerd uitsluitend op deze uitslagen. Een aantal bloed uitslagen duidden op een levensbedreigende situatie, die niet kon worden vastgesteld zonder bloedanalyse (hoofdstuk 5).

Het voordeel van de centralisatie van intensieve zorg voor kritisch zieke kinderen kan alleen bereikt worden als de risico's van het transport zo minimaal mogelijk zijn. Professionele transportteams voor patiënten die intensieve zorg behoeven kunnen een betere stabilisatie bereiken vooraf aan het transport, hebben minder complicaties tijdens het transport en een beter resultaat in vergelijking met onervaren begeleiders. Een landelijke organisatie voor de transporten van kritisch zieke kinderen met een continue bereikbaarheid en inzetbaarheid kan bereikt worden door een organisatie op regionaal niveau, waarbij een topklinisch centrum niet alleen de transporten uitvoert binnen de regio maar tevens deelneemt aan de scholing op het gebied van de opvang van kritisch zieke kinderen in de regionale ziekenhuizen. Succesvolle regionalisatie van pediatrische intensieve zorg hangt af van een goede infrastructuur voor de aanmelding en het transport van kritisch zieke kinderen. Deze infrastructuur moet ontwikkeld worden rondom de behoefte van de patiënt en de verwijzende ziekenhuizen in de regio. De verwijzende ziekenhuizen zijn verantwoordelijk voor de eerste behandeling van de patiënt volgens de richtlijnen van de Advanced Pediatric Life Support en de topklinische centra zijn verantwoordelijk voor het interklinische transport. De acht centra met een PICU hebben reeds een aanvang gemaakt met de invoering van deze organisatiestructuur. Het 


\section{Hoofdstuk 7}

grootste probleem dat deze ontwikkeling in de weg staat is een tekort aan medisch en verpleegkundig personeel binnen de acht PICU's en binnen de ambulancediensten.

Met de ziekenhuizen in de regio dienen schriftelijke afspraken gemaakt te worden betreffende de verantwoordelijkheden van zowel het verwijzend ziekenhuis als het topklinische centrum aangaande de behandeling van de patiënten. Beroepsaansprakelijkheids- en arbeidsongeschiktheidsverzekering voor de personen die deel uitmaken van de transportteams dienen geregeld te worden. Om de kwaliteit van en behoefte aan interklinische transporten van kritisch zieke kinderen te vervolgen is een landelijke gegevensbank van transporten vereist (hoofdstuk 6).

Centralisatie van pediatrische intensieve zorg in Nederland moet verder doorgevoerd worden door uitbreiding van het aantal bedden binnen de huidige PICU's van de acht academische ziekenhuizen en het volgen van de richtlijnen voor overplaatsing van kritisch zieke kinderen naar deze centra. Professionele intensieve zorg transport teams voor kinderen moeten permanent inzetbaar zijn en bestaan uit medisch en verpleegkundige specialisten getraind op het gebied van pediatrische intensieve zorg en intensieve zorg transport. Voor de Nederlandse situatie is regionalisatie de beste organisatievorm, waarbij elke PICU verantwoordelijk is voor de organisatie en uitvoering van transporten in haar regio en de verwijzend specialist verantwoordelijk voor de behandeling direct vanaf opname totdat de behandeling wordt overgenomen door het transportteam. Op deze wijze is het mogelijk om in Nederland een optimale zorg te verlenen aan alle kritisch zieke kinderen. 


\section{Curriculum vitae}

Gijsbert Dirk Vos

Born $12^{\text {th }}$ of October 1953 in Eindhoven, The Netherlands

Department of Pediatrics, Division of Pediatric Intensive Care

University Hospital Maastricht

PO box 5800, 6202 AZ Maastricht

The Netherlands

Tel: $\quad+31-43-3875245$

Fax: $\quad+31-43-3875246$

E-mail: gvo@paed.azm.nl

Highschool

1966 - 1972 HBS-B, Gemeentelijk Lyceum, Eindhoven and

Rythovius College, Eersel, The Netherlands

\section{Medical education}

1972 - 1973 Catholic University Leuven, Belgium

1973 - 1981 University of Amsterdam, The Netherlands

\section{Residency and Pediatric training}

1981 - 1982 Residency Internal Medicine and Cardiology, Military Hospital, Utrecht, The Netherlands

1982 - 1986 Pediatric Residency Program,

Academic Medical Center, Amsterdam, The Netherlands

1986 - 1988 Pediatric Intensive Care Fellowship Program,

Academic Medical Center, Amsterdam, The Netherlands

Certification

1981

Medical Doctor

1986 Pediatrician

$1988 \quad$ Pediatric Intensivist

\section{Faculty positions}

1988 - 1990 Pediatric Intensivist,

Academic Medical Center, Amsterdam, The Netherlands

1990 - $\quad$ Pediatric Intensivist,

Head of the Division of Pediatric Intensive Care

University Hospital Maastricht, The Netherlands 


\section{Publications belonging to this thesis}

- Vos GD, RAmSAY G. (2003) Interhospital Pediatric Intensive Care Transport. In: Vincent JL (ed) Yearbook of Intensive Care and Emergency Medicine 2003. (ISBN 3-540-44382-7) Springer, Berlin Heidelberg New York, 791-799

- Vos GD, BuURman WA, VAn WaARdendurg DA, VISSER TPL, DonckeRWolcke RAMG (2003) Interhospital pediatric intensive care transport: a novel mobile pediatric intensive care transport unit based on a standard ambulance trolley. European Journal of Emergency Medicine 10:195-199

- Vos GD, Nieman fHM, Meurs amB, van WaARdenburg da, Ramsay G, DONCKERWOLCKE RAMG (2003) Problems in interhospital pediatric intensive care transport in the Netherlands: results from a survey of general pediatricians. Intensive Care Medicine 29:1555-1559

- Vos GD, nissen A, Nieman fHM, Meurs amb, van WaArdenburg da, Ramsay G, DONCKERWOLCKE RAMG Comparison of the interhospital pediatric intensive care transport in the Netherlands accompanied by the referring specialists with a specialist retrieval team. Intensive Care Medicine, in press

- Vos gd, Ramsay G, van Goor aAC, leroy PlJM, van WaArdenburg Da, DONCKERWOLCKE RAMG Point-of-care technology: a portable whole blood analyser leads to therapeutically interventions during the interhospital transport of critically ill children. European Journal of Emergency Medicine, submitted

\section{Publications}

- Bos JD, SilleVis-Smitt JH, KRIEg SR, BAKKeR PM, Vos GD, VAN ZAANe DJ (1984) Acute disseminated histiocytosis-X: in situ immunophenotyping with monoclonal antibodies. J Cutaneous Pathol 11:59-64

- Vos GD, HeYMANS HSA, URBANUS NAM (1987) Inspiratory stridor and dysphagia because of prolonged oesophageal foreign body. Eur J Pediatr 146:86-87

- Vos GD, VAN DER BLIJ JF, VAN LeEUWEN THM, LOSEKoOt G (1987) De ziekte van Takayasu als oorzaak van myocard infarct bij een zuigeling. (Takayasu disease as a cause of myocardial infarction in an infant.) Ned Tijdschr Geneeskd $131: 1355-1357$

- Vos gD, Wiegman A, Romijn JA, Meurs AmB, Bruins-Stassen MJP, BiJlmer RPGM, VAN LIESHOUT JJ (1989) Niet nekkramp, maar septische shock als schrikbeeld acute meningokokken ziekte. (Not Meningitis, but Septic Shock as a Fear in Meningococcal Disease) Ned Tijdschr Geneeskd 133:772-775 
- Wijburg fa, Barth PG, Ruitenbeek W, Wanders RJa, Vos Gd, Ploos van AMSTEL SLB, SCHUTGENS RBH (1989) Familial NADH-CoQ oxidoreductase (complex I) deficiency: Variable expression and possible treatment. J Inherit Metab Dis 12:349-351

- Wijburg FA, WANDERs RJA, Vos GD, Bolhuis PA, RUITENBEek W, VAN WiLSem A, TEN HOUTEN R, BARTH PG (1991) NADH:Q1 Oxidoreductase deficiency without lactic acidosis in a patient with Leigh syndrome: implications for the diagnosis of inborn errors of the respiratory chain. $J$ Inherit Metab Dis 14:297-300

- Wijburg Fa, Rosenblatt DS, Vos GD, Oorthuys JWE, van 't Hek LGFM, PoORThuIS BJHM, SANDERS MK, Schutgens RBH (1992) Clinical and biochemical observations in a patient with Pompe disease and cblC mutation. Eur J Pediatr 151:127-131

- Jacobs JA, HendRIKS JJE, Verschure PDMM, VAN DER WuRfF AM, Freling G, VOS GD, STOBBERINGH EE (1993) Meningitis due to Fusobacterium necrophorum subspecies necrophorum. Case report and review of the literature. Infection 21:57-60

- Oberndorff K, Hazenbroek F, Vos GD, Heineman E (1994) Pediatrisch Reanimatie en Interventie Lint, een hulpmiddel bij de eerste opvang van kinderen in levensbedreigende situaties. (Pediatric Resuscitation and Intervention Tape, a resource for the first intervention in children in life threatening situations.) Ned Tijdschr Geneeskd 138:2283-2285

- Meulenbroeks AaWM, Vos GD, Van der Beek JMH and KitselaAr PJeHM (1995) An unexpected cause of upper airway obstruction. J Laryngol Otol 109:252-254

- Vos GD, marres EH, heineman E, Janssens MJ (1995) Tension pneumoperitoneum as an early complication after adenotonsillectomy. J Laryngol Otol 109:440-441

- Degraeuwe PLJ, Vos GD, Blanco CE (1995) Perfluorochemical liquid ventilation: from the animal laboratory to the intensive care unit. Int $\mathrm{J}$ Artif Organs 18: $674-683$

- Vos GD, RiJTema MN, HendRiKs JJE and Ramsay G (1995) Meningococcal septic shock in children: Can outcome and prognosis be influenced? Clin Intensive Care (International Journal of Critical Care Medicine) suppl 6:11

- Bakker SJL, Vos GD, Verschure PdMM, Mulder AH, Tiebosch ATMG (1996) Abnormal glomerular basement membrane in idiopathic multicentric osteolysis. Pediatr Nephrol 10:200-202 
- Van StraAten EA, Hendriks JJE, Ramsay G, Vos GD. (1996) Rhabdomyolysis and pulmonary hypertension in a child, possibly due to long term high dose propofol infusion. Intensive Care Med 22:997-1001

- Vos GD, RIJTEMA MN, BLANCO CE (1996) Treatment of respiratory failure due to respiratory syncytial virus pneumonia with natural surfactant. Pediatric Pulmonol 22:412-415

- Vos GD, VAn StraAten EA, HendRIKS JJE, RAMSAY G (1997) Longterm sedation with propofol contraindicated in children. Ned Tijdschr Geneeskd 141:1072

- HENDRIKS JJE, BERG JP, Vos GD (1997) Three years experience with the upperairway-obstruction team. Clinical Otolaryngol 22: 472-481

- Vos GD, Nix W, Berg JP, van WaARdenburg DA, Hendriks JJE (1997) Acute upper airway obstruction in children with epiglottis or croup: complications due to endotracheal intubation. Clinical Otolaryngol 22:472-481

- De Priester jA, Vos GD, van WaArdenburg DA, Oei TK (1998) Congenitally short trachea with compression of left mainstem bronchus: MRI findings. Pediatric Radiol 28:342-343

- Degraeuwe PL, Thunnissen FB, Vos GD, BLanco CE (1999) High-frequency oscillatory ventilation, partial liquid ventilation, or conventional mechanical ventilation in newborn piglets with saline lavage-induced acute lung injury. A comparison of gas-exchange efficacy and lung histomorphology. Biol Neonate 75:118-129

- Pietersen-Oberndorff KMEJ, Vos GD, BAeten CGMI (1999) Serious complications after incomplete removal of percutaneous endoscopic gastrostomy catheter. J Pediatr Gastroenterol Nutr 28:230-232

- Degraeuwe PlJ, Vos GD, Geskens GG, Geilen JM, Blanco Ce (2000) Effect of perfluorochemical liquid ventilation on cardiac output and blood pressure variability in neonatal piglets with respiratory insufficiency. Pediatr Pulmonol 30:114-124

- Vos GD, VAN GoOr AC, LeClercq W, VAN WAardenbuRg DA, JANSEN NJG, VAN OERLE R, HEMKER HC, HAMULYAK K. (2001) Relationship between ETP, Fibrinogen, D-Dimers, Protein $\mathrm{C}$, and antithrombin and severity of skin and limb necrosis in children with fulminant meningococcal disease. Abstract ISTH, Parijs

- WaArdenburg da van, Deutz nep, hoos mB, Jansen nJg, Kreel BK van, VOS GD, WAGENMAKERS AJ, FORGET PP. (2003) Assessment of whole body protein metabolism in critically ill children: Can we use the $\left[{ }^{15} \mathrm{~N}\right] \mathrm{Glycine}$ single oral dose method? Clinical Nutrition (in press) 


\section{Dankwoord}

Het dankwoord is waarschijnlijk het meest gelezen gedeelte van een proefschrift. Het biedt mij dan ook een unieke kans om al degenen die bijgedragen hebben tot de ontwikkeling van de pediatrische intensieve zorg in het azM, de faciliteit voor het transport van kritisch zieke kinderen binnen de regio zuidoost Nederland en daarmee ook de studies die ten grondslag liggen aan dit proefschrift te danken voor hun enthousiasme, inzet en kameraadschap in de afgelopen jaren. Mijn dank gaat daarbij uit naar:

- De medisch specialisten van de capaciteitsgroep kindergeneeskunde, in het bijzonder mijn collega kinderarts-intensivisten en zij die participeren of geparticipeerd hebben in de diensten van de pediatrische intensieve zorg afdeling,

- De verpleegkundigen van de pediatrische intensieve zorg afdeling, de kinderafdeling, de spoedeisende hulp en de operatieafdeling,

- De medisch specialisten van andere disciplines die zo noodzakelijk zijn voor de behandeling en zorg van onze patiënten,

- De arts-assistenten, met name van de kindergeneeskunde,

- Het secretariaat van de capaciteitsgroep kindergeneeskunde, in het bijzonder mijn eigen secretaresse,

- Alle ondersteunende disciplines, zoals fysiotherapie, pedagogisch team, laboranten van allerlei pluimage, interieurverzorgers en vele anderen zonder wie het onmogelijk zou zijn om als specialistische verpleegafdeling te functioneren,

- Het personeel van de ambulancedienst Zuidelijk Zuid-Limburg,

- De Raad van Bestuur van het azM, die altijd de ontwikkelingen van de pediatrische intensieve zorg hebben gesteund en mogelijk gemaakt,

- De kinderartsen werkzaam in de ziekenhuizen binnen en buiten de regio, die hun vertrouwen hebben in en hun patiënten toevertrouwen aan onze zorg,

- De kinderen en hun ouders die in de afgelopen jaren onze zorg nodig hadden,

- Al degenen die hebben geholpen bij het tot stand komen van dit proefschrift, met name mijn promotoren,

- Mijn vrouw en kinderen, zonder hen zou het voor mij onmogelijk zijn geweest om de weg die ik voor ogen had met de pediatrische intensieve zorg in Maastricht en in de regio af te leggen,

- En al degenen die niet genoemd zijn. 